\begin{abstract}
UNIVERSIDADE DE SÃO PAULO
FACULDADE DE FILOSOFIA, LETRAS E CIÊNCIAS HUMANAS

DEPARTAMENTO DE HISTÓRIA

PROGRAMA DE PÓS-GRADUAÇÃO EM HISTÓRIA SOCIAL
\end{abstract}

WILLIAN GAMA DOS SANTOS

A POLÍTICA DE CIÊNCIA E TECNOLOGIA E O MODELO BRASILEIRO DE DESENVOLVIMENTO NA FORMAÇÃO DO POLO TECNOLÓGICO DE CAMPINAS

\author{
São Paulo - SP \\ Versão Corrigida
}

2017 


\section{A POLÍTICA DE CIÊNCIA E TECNOLOGIA E O MODELO BRASILEIRO DE DESENVOLVIMENTO NA FORMAÇÃO DO POLO TECNOLÓGICO DE CAMPINAS}

Dissertação submetida ao Programa de Pós Graduação em História Social do Departamento de História da Faculdade de Filosofia, Letras e Ciências Humanas da Universidade de São Paulo, como requesito para a obtenção do título de Mestre em História Social.

Orientador: Prof. Dr. Shozo Motoyama

$$
\text { São Paulo - SP }
$$

\section{Versão Corrigida}




\section{A POLÍTICA DE CIÊNCIA E TECNOLOGIA E O MODELO BRASILEIRO DE DESENVOLVIMENTO NA FORMAÇÃO DO POLO TECNOLÓGICO DE CAMPINAS}

\section{BANCA EXAMINADORA}

Orientador: Prof. Dr. Shozo Motoyama

FFLCH-USP

Prof. Dr. Alexandre Macchione Saes

FEA-USP

Prof. Dr. Francisco Assis de Queiroz

FFLCH-USP

São Paulo - SP

2017 
SANTOS, Willian Gama dos. A Política de Ciência e Tecnologia e o Modelo Brasileiro de Desenvolvimento na Formação do Polo Tecnológico de Campinas. Dissertação (Mestrado em História Social) - Universidade de São Paulo, São Paulo, 2017.

\section{RESUMO}

Nessa dissertação pretendemos analisar como o Estado brasileiro participou da construção das instituições de ensino e pesquisa na cidade de Campinas e de como essa estrutura foi mobilizada no sentido de realizar parte das iniciativas desenvolvimentistas presentes no Modelo Brasileiro de Desenvolvimento.

Além da análise sobre a relação existente entre as políticas de ciência e tecnologia e o planejamento econômico do regime militar, pretendemos demonstrar quais as estruturas políticas e sociais que permitiram a formação de um polo tecnológico na cidade de Campinas. Procuraremos descrever como o processo de crescimento da economia local permitiu o surgimento de uma nova modalidade de produção baseada na alta tecnologia, e como o conteúdo tecnológico foi mobilizado pela academia científica e instituições de pesquisa da cidade.

Palavras chave: Governo Militar, Desenvolvimento Econômico, Planejamento Econômico, Utopia, História Contemporânea. 
SANTOS, Willian Gama dos. The Politics of Science and Technology and the Brazilian Development Model in the Formation of the Technological Pole of Campinas. Dissertation (Master's Degree Dissertation) - University of São Paulo, São Paulo, 2017.

\begin{abstract}
This dissertation aims to analyze how the Brazilian State participated in the creation of educational and research institutions in the city of Campinas and how this structure was used in order to execute part of the developmental initiatives found in the Brazilian Development Model.

Besides the analysis of the relationship between the economic planning of the military regime and science and technology policies, we aim to reveal the political and social structures that supported the development of a technological pole in the city of Campinas. We will describe how the local economy growth process supported the rise of a new modality of production based on the high technology, and how the technological content was used by the scientific academy and research institutions of the city.
\end{abstract}

Key Words: Military Government, Economic Development, Economic Planning, Utopia, Contemporary History. 


\section{AGRADECIMENTOS}

Em um país onde o acesso à educação formal ainda é um privilégio, alcançar o ensino superior é um desafio para muitas famílias. Gostaria de começar esses agradecimentos lembrando os esforços concentrados de meus parentes. Graças ao constante estímulo e dedicação de minha família pude ter condições de dar prosseguimento aos meus estudos.

Assim, agradeço a minha mãe, Benedita Maria Gama Gaspar, que nunca deixou os seus filhos esquecerem o valor do estudo e do esforço individual, e que mesmo durante as maiores dificuldades encontrou caminhos de nos manter unidos e confiantes. Agradeço também ao grande amigo, parte fundamental de nossa família, Aristides Mouta Gaspar, que passou muitas noites me ajudando nas tarefas escolares e que pude contar em inúmeros momentos de minha vida. Não poderia deixar de agradecer aos meus irmãos, Fernando Gama dos Santos e Vitória Gama Gaspar, pela amizade, apoio incondicional e alegria nos momentos de descontração.

Agradeço a sabedoria e cuidado de minha avó, Maria Contessa Gama. Dona de uma visão de mundo generosa, capaz de cuidar e instruir nas pequenas e grandes coisas, uma eterna fonte de inspiração. Agradeço ao grande contador de histórias e saudoso avô, Dilson Gama, que permitiu que minha primeira infância fosse marcada pela liberdade do brincar.

Representando meu grande círculo familiar, com quem sempre pude contar com incentivo e apoio, uma lembrança especial ao saudoso Douglas Augusto Gama, que infelizmente não pode acompanhar a conclusão desse trabalho, mas que me contagiou ainda menino com seu apreço pelos livros, sua inteligência excepcional e sua ilimitada capacidade de viver.

Dentro da Universidade de São Paulo, no Departamento de História, tive professores brilhantes, que, além de minha formação profissional, proporcionaram a abertura de largos horizontes intelectuais. Transmito aqui meu sincero agradecimento a esses profissionais. 
Fiz essa pesquisa sem nenhum apoio financeiro, contando apenas com meus próprios recursos. Essa é a condição de inúmeros pesquisadores no Brasil, situação na qual a atividade científica tornasse-se um ofício realizado por convicção. Nesse estado das coisas não existem heróis, existem apenas sobreviventes. Que nossa persistência e inconformidade com o estado das coisas pavimentem caminhos que permitam a melhoria substancial para uma atividade que é fundamental ao nosso país. Aguardamos tempos melhores.

Contrabalanceando os dissabores, pude contar com o suporte fundamental de alguns indivíduos e instituições. Em primeiro lugar gostaria de agradecer o professor Shozo Motoyama que demonstrou constante apoio e confiança em meu trabalho. Tenho a honra de fazer parte de um grande grupo de pesquisadores que ingressaram na pesquisa acadêmica graças à generosidade e confiança de um intelectual ímpar na academia científica brasileira.

Também agradeço aos professores Alexandre Macchione Saes e Francisco Assis Queiroz, que proporcionaram uma significativa contribuição a essa pesquisa com seus comentários e sugestões oportunas transmitidas na banca de qualificação desse trabalho. Meus agradecimentos se estendem aos funcionários do sistema de bibliotecas da Universidade de São Paulo, pela atenção e constante ajuda. Gostaria de ressaltar principalmente o espaço da Biblioteca Florestan Fernandes, que foi de enorme valia nessa pesquisa. Aos funcionários do CPDOC/FGV pela disponibilidade e esclarecimentos, esse centro de documentação é fundamental para a atividade de pesquisa em história no Brasil.

Agradeço aos professores José Ellis Ripper, Rogério Cezar Cerqueira Leite e Saul Gonçalves D’Ávila. A gentileza, simpatia e desimpedimento demonstrados durante a realização das entrevistas foram substanciais para o desenvolvimento desse trabalho. Tais ocasiões foram momentos de intenso aprendizado.

Meus sinceros agradecimentos às secretárias e secretários que me atenderam e auxiliaram durante a realização dessa pesquisa, tais profissionais ficam representados na extrema competência da infatigável Adriana Casagrande de Luca, em razão do seu trabalho pude navegar na complexa burocracia universitária durante todos esses anos. 
Ademais, não poderia deixar de lembrar os colegas e pesquisadores do Centro Interunidade de História da Ciência (CHC-USP). Graças às discussões e estudos conjuntos pude me inspirar e trocar ideias que se mostraram fundamentais para o andamento dessa pesquisa. Meus sinceros agradecimentos a todos!

Aos inúmeros amigos e amigas que estiveram por perto durante todo esse período e que me apoiaram em todas as etapas desse longo processo. Não quero cometer a injustiça de esquecer alguém, portanto sintam-se coletivamente abraçados!

Durante esses anos os meus sogros forneceram constante incentivo. Meus agradecimentos ao Sr. Nobuyuki Koda, e a Sra. Mineko Yamazato Koda pela confiança irrestrita e convivência agradável.

Por último reservo um espaço especial para agradecer a minha companheira Mirna Yamazado Koda. Além de sua colaboração inestimável para o desenvolvimento dessa pesquisa, pude também contar com seu carinho e apoio em todos esses anos. Pelo privilégio da companhia instigadora, pela gentileza e erudição, e principalmente, pelo amor demonstrado, meu eterno obrigado! 
“Os homens fazem a sua própria história, mas não a fazem como querem; não a fazem sob circunstâncias de sua escolha e sim sob aquelas com que se defrontam diretamente, legadas e transmitidas pelo passado.” Karl Marx

“As coisas são descobertas por meio das lembranças que se têm delas. Relembrar uma coisa significa vê-la - apenas agora - pela primeira vez”. Cesare Pavese 


\section{Sumário}

INTRODUÇÃO.

Capítulo 1 - A CIÊNCIA E TECNOLOGIA COMO POLÍTICA DE ESTADO: CONDIÇÕES

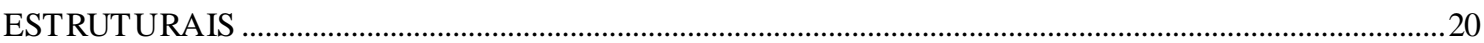

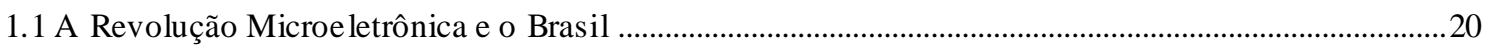

1.2 Planejamento e Teoria Econômica Desenvolvimentista no Brasil: A Emergência do Estado Desenvolvimentis ta e Industrializante

1.3 Ciência e Tecnologia durante o Regime Militar: Possibilidades e Limites do Modelo Brasileiro de

Desenvolvimento .38

Capítulo 2 - PRAGMATISMO E UTOPIA: AS BASES HISTÓRICAS DO POLO TECNOLÓGICO DE CAMPINAS

2.1 Campinas: Frente Pioneira de expansão colonial, o ciclo do café e a modernização industrial ..... 49

2.2 Ciência e Economia na Construção do Eldorado Tecnológico: O Caso do Vale do Silício 64

2.3 Do Vale do Silício à Campinas: Pesquisa e Desenvolvimento e Instituições de Ensino Superior a Serviço do Modelo Brasileiro de Desenvolvimento .75

Capítulo 3 - DA TOTALIDADE AO PARTICULAR: VISÕES SOBRE O POLO TECNOLÓGICO DE CAMPINAS ATRA VÉS DAS LENTES DA HISTÓRIA ORA L …............................................................ 100

3.1 A História Oral e a Análise Historiográfica ............................................................................................. 100

3.2 A Política de C\&T Brasileira após o Golpe de 1964 .................................................................................103

3.3 O Modelo Brasileiro de Desenvolvimento Incorpora a Ciência e Tecnologia ......................................112

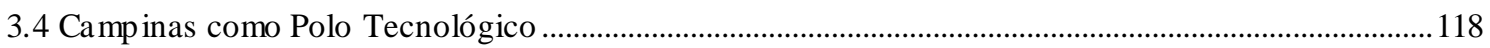

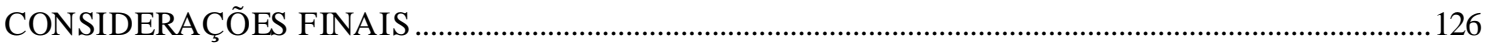

PARTE III - Docu mentação e Referênc ias Bibliográficas ............................................................................... 139

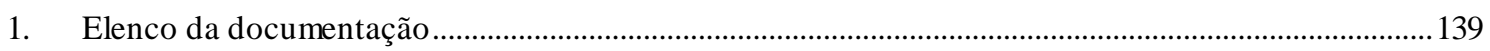

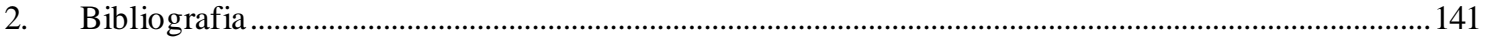




\section{INTRODUÇÃo}

O surgimento, no Brasil e no exterior, de polos científico-tecnológicos, doravante nomeados de polos tecnológicos, advém de uma complexa conjuntura histórica de caráter global que tem recebido atenção sistemática das Ciências Humanas há pelo menos três décadas ${ }^{1}$.

Particularmente no Brasil, os polos tecnológicos começam a se constituir a partir de Universidades e excepcionalmente no caso de Santa Rita do Sapucaí, a partir de Escolas Técnicas (QUEIROZ,2007). A região de São José dos Campos inaugura essa nova forma produtiva com o desenvolvimento de uma indústria bélica e aeronáutica, ainda na década de 1960 (RIBEIRO,1994). Nas próximas três décadas, foi constatado o aparecimento de polos tecnológicos em diversas cidades do país: Campina Grande-PB, Campinas-SP, Florianópolis-SC, Recife-PE, Santa Rita do Sapucaí-MG, São Carlos-SP (GOMES, 1995), e outras.

O surgimento e desenvolvimento dos Polos Tecnológicos, no Brasil, se deu através do imbricamento de diversos elementos constituintes de nossa sociedade. Desde o avanço da Ciência e Tecnologia (doravante nomeada como C\&T) nacionais (MAGALHÃES,1994), passando pelo desenvolvimento do Ensino Superior, PósGraduação e Pesquisa e Desenvolvimento (doravante nomeada como P\&D) (MOTOYAMA,2004). Articulado ao processo de desenvolvimento científico, também são relevantes na formatação dessa nova unidade tecnoprodutiva as necessidades econômicas de um país em desenvolvimento e as aspirações conflitantes dos militares que governavam o país nessa conjuntura, somamos também, o impacto dessas questões nas Políticas de Ciência e Tecnologia oficiais (MOTOYAMA, 1999).

1 Sobre o surgimento, dinâmica e evolução dos polos tecnológicos consultar: CASTELLS, Manuel e HALl, Peter. 1999. DEMATTOS, M. GOMES, E. J.1995. GOMES, E. J. 1998. LAHORGUE, M. A. 2006. LIMA, L. C. In: SANTOS, Milton (Org.).1997. p. 285-289. MARCOVICH, Jacques.1988. MEDEIROS, J. A. 1995. MOTOYAMA, Shozo, QUEIROZ, Francisco A. de e VARGAS, Milton. In: MOTOYAMA, 2004, capítulo 5, pp. 317-385. QUEIROZ, F.A. de. 2007. SIQUEIRA, T. V. 2003. FORESTER, TOM. 1990. 
Colateralmente a esses elementos estruturais, existem outras questões não menos importantes de caráter micro históricos, como, por exemplo, o fator determinante dos anseios e objetivos dos sujeitos envolvidos no planejamento e na realização dos Polos Tecnológicos (QUEIROZ, 2007), a disponibilidade de investimento para uma área considerada de risco pelo mercado (LIMA, 1997) e a existência de um apoio eficaz do governo local, estadual e federal (GOMES,1995), etc. Essas questões colaterais são escassamente analisadas pela bibliografia disponível para esse tema.

Conforme foi brevemente apresentado, é íntima a relação entre o desenvolvimento de Polos Tecnológicos e as Universidades, assim como o desenvolvimento da C\&T e da P\&D nacionais também são elementos que entram nesse processo.

Exatamente na confluência das possibilidades desenvolvimentistas permitidas pelos Polos Tecnológicos contemporâneos, no arranjo das estruturas econômicas defendida pelo governo militar dos anos 70, e nas limitações inerentes a essas estruturas, que se concentraram grande parte das críticas em torno da realização, e implementação, de tais unidades econômico-produtiva-tecnológicas.

Alguns autores identificam um excesso de "fantasia" e "mito" embasando a formação de tais polos tecnológicos (TAVARES, 1997), na medida em que as expectativas tenderam a se afastar da lógica dos processos produtivos reais do capitalismo e de sua natureza contraditória. Outros autores analisam que o progresso tecnológico historicamente gerou uma série de utopias - e consequentemente potenciais distopias e eutopias - análise que ressalta o progresso tecnológico como fonte inspiradora de "Eldorados" que mobilizaram a imaginação humana (QUEIROZ, 2007).

Verificamos que a criação de polos tecnológicos não escapou dessa dinâmica utópica. Análises sociais e econômicas demonstram que o sucesso dos polos tecnológicos depende de uma combinação "alquímica" de elementos sociais, políticos e econômicos (CASTELLS; HALL, 1994). Objetivo alcançado em limitados casos particulares - o Vale do Silício é o grande paradigma exemplar - e tais casos têm inspirado inúmeras tentativas de cópias. Observando tais processos, alguns autores enxergam nesse fenômeno o "Eldorado" do século XXI, pois muitos polos são criados 
ao serem vendidos por seus idealizadores como "fantasias de alta tecnologia" (CASTELLS; HALL, 1994, p.237).

Para além da análise da base ideológica que sustenta a formação dos polos tecnológicos, pesquisas sobre os resultados sociais e econômicos desse arranjo produtivo técnico-científico, como a realizada por Hermes M. Tavares (TAVARES, 1997), destacam uma série de questões que afastam tais experiências do reino do mito e da fantasia, alertando quanto às contradições e desafios existentes. Cabe ao menos apresentarmos algumas dessas questões levantadas.

Podemos começar com a desconstrução da ideia de que os resultados dos investimentos em ciência e tecnologia teriam, seguramente, efeitos multiplicadores. Nos Estados Unidos, território onde os polos tecnológicos conseguiram os mais expressivos resultados, de cada cem projetos de capitais de risco, $10 \%$ são bem sucedidos, $30 \%$ apresentam resultados parciais e 60\% fracassam (LIMA, 1997). É importante observar esses números, pois são pertinentes para o entendimento do desenvolvimento embrionário das indústrias voltadas para a P\&D com base na eletrônica e informatização, que apesar de não se desenvolverem exclusivamente em polos tecnológicos, estão essencialmente ligados a esses núcleos (TAVARES, 1997). Também se relativizou a presença de investimentos privados nessa área, pois no caso norteamericano ouve um grande incentivo da indústria bélica patrocinada por demandas governamentais. Exemplo desse apoio estatal pode ser visto no Japão, em Tsukuba, onde o Estado investiu US\$5,5 bilhões na concepção dessa cidade científica (CASTELLS, 1994). Outro exemplo é o próprio Brasil, onde praticamente inexistiu investimento privado de risco na consecução de polos tecnológicos (TAVARES, 1997).

Outra questão ponderada é que o desenvolvimento regional a partir do tecnopolo acontece apenas na confluência de um ambiente adequado com um meio industrial permeado por uma cultura técnica, portanto trata-se mais de uma lógica capitalista de concentração dos fatores de produção do que um desenvolvimento social espacial. Contrapondo-se a ideia de que os polos tecnológicos ajudam a equilibrar um território, alguns autores entendem que os polos atuam de maneira a acentuar o desenvolvimento desigual, pois diferenciam e hierarquizam o espaço. Por fim, a relação do tecnopolo 
como fator de distribuição de renda e de preservação dos recursos ambientais sofre questionamentos, na medida em que as pesquisas apontam um crescente distanciamento entre os trabalhadores possuidores de conhecimento científico dos que não o possuem e que cidades da Califórnia possuidoras de indústrias de alta-tecnologia sofreram degradações em seu meio ambiente devido a indústria tecnológica (TAVARES, 1997).

Conforme demonstramos brevemente, diversos trabalhos levantam uma série de questões quanto ao sucesso e viabilidade econômica/social dos polos tecnológicos. Situamos também que uma das grandes metas pretendidas pelo desenvolvimentismo, projeto defendido por certos grupos do governo-militar, era a consolidação de uma estrutura técnico-científica capaz de amparar o desenvolvimento nacional.

Este projeto foi elaborado tendo em vista essas questões apresentadas e inspirado na proposição sugerida por Manuel Castells e Peter Hall, que entendem que para se aprofundar as análises sobre os Polos Tecnológicos, cabe pesquisar os objetivos históricos que esses empreendimentos buscaram realizar (CASTELLS, 1994).

Partindo desse pressuposto metodológico, a pesquisa desenvolvida nesta dissertação teve início com o propósito de estudar como eram as relações existentes entre o Estado Brasileiro atuante na segunda metade do século XX, o campo da Ciência e Tecnologia durante essa conjuntura e como o "Modelo Brasileiro de Desenvolvimento", proposto e executado pelo regime militar entre os anos de 1964 a 1985, influenciou nessas questões. Para abordar tais indagações escolhemos investigar o processo histórico da formação do polo tecnológico de Campinas. Pretendemos com essa abordagem "testar os modelos explicativos" (CERTEAU. p.114, 1982) que a historiografia produziu para esclarecer os fatores presentes no surgimento de tais unidades produtivas, fatores esses que foram abordados nos parágrafos anteriores.

A escolha da análise do surgimento do polo tecnológico nessa cidade se deve principalmente ao fato de que, naquele ambiente, uma conjunção de elementos fundamentais na constituição da estrutura desenvolvimentista militar estava presente e operante. Podemos citar como exemplo o incentivo ao desenvolvimento da Pós Graduação como fator de estímulo a P\&D e C\&T nacionais, tal incentivo pode ser observado pela formação de uma universidade estadual na região de Campinas, ou 
mesmo pela modernização do sistema de graduação e pós-graduação promovida como política de educação do governo militar; aliada a essas ações oficiais vemos a constituição de grupos sociais associados à visão desenvolvimentista e responsáveis pela criação de locais onde pesquisadores/empreendedores encontravam espaço para aplicar o conhecimento produzido na academia em projetos comuns, a mobilização do conhecimento acadêmico no setor produtivo tinha por fim último um desenvolvimento econômico local de base tecnológica.

Além do estímulo ao desenvolvimento da Pós Graduação e a existência de um núcleo voltado para o empreendedorismo, a região de Campinas já possuía uma estrutura de $\mathrm{P} \& \mathrm{D}$ consolidada, fator decisivo para a existência de um polo tecnológico.

Tal estrutura era formada por uma grande universidade e instituições de pesquisas e desenvolvimento tecnológico, como o centenário IAC (Instituto Agronômico de Campinas) e o CPTA (Centro Tropical de Pesquisas e Tecnologia de Alimentos) atual ITAL (Instituto de Tecnologia de Alimentos). Além dessas instituições, o governo, através da iniciativa da Telebrás, escolheu essa cidade para instalar novos centros de desenvolvimento tecnológico voltados para a telecomunicações e a informática, estamos falando do CPqD (Centro de Pesquisa e Desenvolvimento em Telecomunicações - Padre Roberto Landell de Moura ) e do CTI (Centro de Tecnologia da Informação - Renato Archer), que na década de 1970 estavam em processo de estruturação. Aliada a tais centros, na década anterior uma universidade estadual tinha se instalado e aos poucos começava a despontar no cenário nacional, trata-se da UNICAMP (Universidade Estadual de Campinas), dessa universidade partiu as principais iniciativas de formação do polo tecnológico da região.

Outro elemento que estimulou o processo foi a existência de uma eficiente malha de transportes. Campinas tem em seu território ferrovias, um aeroporto e diversas rodovias que possibilitam um deslocamento rápido e eficiente de pessoas e mercadorias naquele espaço.

A aposta do governo e dos pesquisadores locais era de que amparados pela estrutura instalada na região seria possível ativar o potencial científico e tecnológico para produzir um desenvolvimento local baseado na alta tecnologia. 
Pretendemos nessa dissertação aprofundar a análise dessas iniciativas. Entendemos que partes das apostas desenvolvimentistas estavam sendo efetivadas na região de Campinas. Estudar o surgimento do polo tecnológico nessa região permite-nos aprofundar a análise histórica de um processo amplo que se espraiou por todo o território nacional.

Cabe aqui nesse ponto salientar uma importante característica da perspectiva histórica que será norteadora da análise histórica dessa dissertação. Não temos como pretensão desenvolver nesse trabalho a história do polo tecnológico de Campinas. Processo que até hoje ainda está em andamento, mas que ainda não foi realizado, é tema de diversas dissertações, teses e artigos, inclusive citados e analisados nesse trabalho. Nosso foco analítico está nos anos de formação dessa unidade tecnoprodutiva, nas primeiras estruturas que se consolidaram na região e que passaram a ser conhecidas socialmente como um polo tecnológico. O marco cronológico que nos norteará será o ano 1964, momento onde o Brasil viveu o golpe militar e assistiu a instalação do Modelo Brasileiro de Desenvolvimento norteado pela perspectiva da Doutrina de Segurança Nacional. Em 1966 temos a criação da Universidade Estadual de Campinas (UNICAMP), instituição central para a formação do Polo Tecnológico na cidade, e em 1985 vive-se o último ano de governo do regime militar e da desmobilização de um projeto desenvolvimentista que já estava em pleno declínio nos anos anteriores. Identificaremos as condições históricas que permitiram o andamento desse processo.

Para realizar esse objetivo analisaremos as demandas sociais, econômicas e culturais que se imbricaram em um momento histórico específico, formando uma unidade econômica diferente das que existiam até então na região. Quando nos reportarmos aos anos anteriores e posteriores a formação do polo, será no intuito de realizar a análise dos antecedentes e resultados desse processo, conforme apresentado pela bibliografia que se voltou para esse tema.

Para desenvolver a narrativa histórica do surgimento do polo tecnológico de Campinas e o contexto sócio-histórico que permitiu a elaboração desse projeto utilizaremos parte da vasta bibliografia que analisou esse período. Sejam as obras que pretenderam explicar o fenômeno desenvolvimentista no Brasil e suas particularidades, 
os trabalhos que analisaram o processo de constituição do regime militar no Brasil e suas características sociais, políticas e econômicas, a análise do campo da História da Ciência e da Sociologia voltadas para o entendimento das transformações na técnica e ciência e suas múltiplas repercussões na segunda metade do século XX, e a análise da historiografia voltada ao entendimento do surgimento dos Polos Tecnológicos e suas características na cidade de Campinas.

Aliada a essa base historiográfica procuramos identificar os indivíduos representantes da pesquisa acadêmica na região que se aventuraram na mobilização dessas questões de ordem econômica. Tentamos mapear a atuação desses indivíduos e analisar suas motivações, projetos e visões ideológicas para o desenvolvimentismo, C\&T e temas correlatos. Pretendemos relacionar os depoimentos desses indivíduos com as análises acadêmicas já realizadas sobre tais assuntos, tanto no sentido de testar as hipóteses explicativas para esses fatos históricos à luz da História Oral, quanto para aprofundar essas questões e debates, aproveitando a singularidade dos indivíduos e do processo local. Usaremos fontes jornalísticas como complemento a análise historiográfica, e o procedimento metodológico da história oral para construir um panorama o mais complexo possível da região, dos eventos ali ocorridos e da atuação da comunidade acadêmica no momento de formação desse polo tecnológico.

Esta dissertação divide-se em três capítulos. No primeiro capítulo - "A Ciência e Tecnologia Como Política de Estado - Condições Estruturais" - procuraremos apresentar a conjuntura econômica e política no qual estava inserida a elaboração e consecução do projeto do polo tecnológico de Campinas e a historiografia que aborda as relações entre C\&T e P\&D com a sociedade brasileira da segunda metade do século XX. Sabemos que existe uma relação direta entre o conteúdo desenvolvimentista planejado pelo regime militar e os investimentos em C\&T e P\&D. Para acompanhar a evolução dessa questão realizo uma breve análise do processo histórico que permitiu a elaboração das diversas propostas desenvolvimentistas assistidas e implementadas no Brasil, apresentando as raízes do planejamento econômico como política de desenvolvimento nacional, desde sua origem, conforme as elaborações dos economistas ligados ao Estado Novo. A análise acompanha o percurso desenvolvimentista do 
governo Juscelino Kubitschek, concluindo com a elaboração e aplicação do Modelo Brasileiro de Desenvolvimento pelo regime militar, ou seja, a instituição do desenvolvimentismo econômico através do planejamento econômico e a incorporação do viés conservador nas políticas executadas pelo Estado. Após apresentar tal circunstância esboço como o regime militar mobilizou a C\&T nessa estrutura econômica/social ponderando os limites e alcances desse projeto.

O segundo capítulo - "Pragmatismo e Utopia - As bases históricas do Polo Tecnológico de Campinas" - é voltado para a história da cidade de Campinas e da evolução econômica vivenciada nessa região durante o século XX. Para realizar esse percurso apresentamos brevemente a ocupação territorial ocorrida pelo avanço bandeirante no planalto paulista, a partir de então demonstro brevemente como o desenvolvimento industrial da cidade é intimamente relacionado ao passado agrícola da região e a estrutura social/política do período com suas características escravistas e oligárquicas. A partir dessa estrutura histórica demonstramos a evolução econômica da região e a possibilidade do surgimento da atividade industrial de matriz tecnológica, um dos eixos formadores do polo tecnológico de Campinas. Para apresentar a estruturação do polo tecnológico na cidade recuperaremos as origens dessa estrutura técnicoprodutiva no Vale do Silício - Califórnia/EUA. Ao descrevermos a formação do polo tecnológico em Campinas nos concentraremos principalmente em apresentar algumas iniciativas de grupos ligados a Unicamp que permitiram a instalação desse polo tecnológico na cidade e como tais iniciativas estavam intimamente ligadas ao planejamento estratégico proposto pelo regime militar.

Por último propomos um capítulo centrado na análise dos depoimentos coletados em entrevistas de história oral realizadas com os formuladores dos projetos que levaram a criação do polo tecnológico na cidade. Nesse capítulo -"Da Totalidade ao Particular - Visões Sobre o Surgimento do Polo Tecnológico de Campinas de Através das Lentes da História Oral" - pretendo discutir as questões relacionadas aos conteúdos metodológicos e teóricos sobre memória e fonte oral, apresentar um mapa das ideias e conceitos defendidos pelos indivíduos participantes da formação do polo tecnológico na cidade de Campinas, suas visões sobre os temas relacionados à C\&T e P\&D, além de 
suas percepções particulares sobre os processos históricos vivenciados durante o regime militar. Buscaremos correlacionar tais visões com as análises historiográficas desses mesmos processos. 


\section{Capítulo 1 - A CIÊNCIA E TECNOLOGIA COMO POLÍTICA DE ESTADO: CONDIÇÕES ESTRUTURAIS}

\subsection{A Revolução Microeletrônica e o Brasil}

Para entendermos a relação da C\&T com o modelo desenvolvimentista planejado pelo regime militar no Brasil, é preciso ter em mente que esse processo está ligado diretamente a uma conjuntura ampla de alcance global. $\mathrm{O}$ entrelaçamento entre as modernas técnicas da C\&T e P\&D com a economia capitalista é uma das grandes marcas da segunda metade do século XX. Principalmente porque a década 1970 inaugurou um novo paradigma, no qual a intervenção da tecnologia fez-se presente de maneira determinante na reconfiguração social, econômica e cultural verificada nas décadas seguintes ${ }^{2}$.

Esse processo de ampla transformação na estrutura da sociedade capitalista foi proporcionado pelo advento e incorporação da tecnologia da microeletrônica através do uso de computadores dotados de crescente capacidade de processamento de dados. $\mathrm{O}$ desenvolvimento do primeiro computador programável, o ENIAC (Eletronic Numerical Integrator and Calculator), construído com incentivo do Exército americano logo após a Segunda Guerra Mundial (FORESTER, 1990), deu início ao desenvolvimento de tecnologias que posteriormente produziriam resultados surpreendentes no conjunto das relações superestruturais do capitalismo.

Poucos anos após o surgimento dos primeiros computadores, análises surgidas no âmbito das ciências sociais começaram a estudar o resultado da interação dessa nova tecnologia com a sociedade. Um dos pioneiros nesse processo foi o antropólogo japonês Tadao Umesao, que propôs no artigo "A Indústria da Informação" (Joho Sangyo Ron) (UMESAO, 1963) uma teoria evolucionária da história humana indicando que ao dominar a técnica do processamento de dados a sociedade alcançava um novo patamar. Com essa teoria da história de caráter marcadamente evolucionista o autor enfatizava

\footnotetext{
${ }^{2}$ Para um estudo aprofundado sobre esse processo ver: CASTELLS, M. 1999. A Sociedade em Rede.
} 
que com o desenvolvimento de computadores e mídias de massa, a informação se tornara um importante fator econômico.

A teoria proposta por Umesao foi acolhida e expandida através da atuação de futurólogos como Masuda e Hayashi. Posteriormente o impacto das ideias que propunham a emergência de uma "sociedade da informação" (Jakoha Shakai) passou a nortear o planejamento econômico elaborado pelo Estado japonês. Na década de 1970 o Japão converteu boa parte de sua indústria e pesquisa para o desenvolvimento de eletrônicos, tornando-se grande exportador desses produtos, ao mesmo tempo em que essas novas tecnologias eram inseridas extensivamente na sociedade japonesa. A ideologia da sociedade da informação como nova etapa do desenvolvimento do país se tornou o cerne das políticas de P\&D e C\&T. Exercícios de futurologia subsidiados pelo governo passaram a operar tanto em escala federal quanto municipal e grandes projetos de modernização tecnológica surgiram nesse contexto (CASTELLS, 1999).

No ocidente, estudos sobre o caráter transformador da microeletrônica também foram elaborados. Conceitos como Pós-Industrialismo (BELL,1969), e Era Tecnetrônica (BRZEZINSKI,1971), foram criados na tentativa de explicar esse nova conjuntura histórica.

Vemos que o alcance e potencialidade das transformações em curso eram marcantes a ponto de os países desenvolvidos simplesmente não poderem deixar de analisar tal fenômeno. Tais análises muitas vezes ganham ares de futurologia, principalmente quando os ideólogos da Revolução Microeletrônica tentaram predizer os rumos para os quais esse processo caminharia.

Daniel Bell estruturou o campo teórico voltado para a análise dessa sociedade em construção. Para marcar a singularidade do momento criou o termo PósIndustrialismo (BELL,1969). Brzezinski reelaborou esse conceito ao criar o termo Era Tecnetrônica. Ambos os trabalhos destacam-se por propor que as transformações na C\&T e P\&D, em curso nos países desenvolvidos da segunda metade do século XX, estavam criando condições para uma superação estrutural do modo de produção baseado no industrialismo. 
Pensadores de matriz liberal preocuparam-se em elaborar uma teoria que identificasse $o$ impacto dessas transformações tecnológicas na reconfiguração da sociabilidade, produção e mesmo da subjetividade humana.

A análise de Daniel Bell propõe a emergência de um ambiente sociocultural que caminhava para o surgimento de uma nova etapa histórica marcada pelo fim das ideologias. Tal análise posteriormente germinou em teorias sociológicas no final do século XX que propunham o fim da história ${ }^{3}$.

Brzezinski não ousou tanto em suas previsões. Mas não deixou de apontar a volatilidade das ideologias nessa nova era tecnológica, apontando como sintoma desse fenômeno o que ele identificava como o declínio das organizações políticas surgidas durante a Era Industrial e o descompasso das esquerdas em um mundo em transformação. De acordo com essa análise, em um mundo regido pelas forças econômicas do pós-industrialismo, com uma sociedade moldada pelas novas ferramentas de comunicação, as convicções políticas de um momento histórico anterior e, portanto, obsoleto, estariam em xeque. Imagina-se no horizonte de médio e longo prazo novos arranjos políticos em sintonia a essa nova fase histórica e o declínio definitivo das organizações baseadas nos ideais socialistas. Dentro dessa conjuntura, grupos e intelectuais de esquerda são tratados como portadores de uma "ideologia infantil" (BRZEZINSKI,1971. p.201) ao não se adequarem as novas configurações econômica, sociais e tecnológicas. Como resultado desse processo, a Era Tecnetrônica seria o momento culminante do liberalismo.

Brzezinski preocupou-se em analisar os riscos que ameaçam o poder americano e os vetores pelos quais tal poder poderia ser multiplicado e estabelecido. Graças a sua atividade acadêmica, no governo Carter (1977 - 1981) assumiu uma cadeira no Conselho de Segurança Nacional dos Estados Unidos.

Uma das primeiras obras na qual apresenta uma análise estruturada sobre a política e sociedade na metade do século XX é o livro, América: Laboratório do Mundo: A Era Tecnetrônica e o Desafio Universal. A síntese desse trabalho, produzido em 1969,

\footnotetext{
${ }^{3}$ O trabalho mais citado sobre esse tema é o de: FUKUYAMA, F. 1992. O Fim da História e o Último Homem.
} 
no Instituto de Pesquisas de Assuntos Comunistas da Universidade de Columbia, é de que os Estados Unidos deveriam controlar e assegurar sua proeminência sobre as novas tecnologias que estavam em curso. A sociedade tecnetrônica que estava sendo estruturada naquele exato momento seria uma sociedade diretamente moldada pelo impacto da tecnologia e da eletrônica em seus mais diferentes níveis. A relação entre a posse do conhecimento técnico-científico e a manutenção da hegemonia global mais do que nunca era direta e determinante.

Conforme podemos ver, em sua origem, as análises sobre as mudanças tecnológicas promovidas pela Revolução da Microeletrônica confundiam-se com o planejamento estratégico do poder estadunidense e do desenvolvimentismo elaborado pela burocracia estatal japonesa. O caso americano se destaca nesse contexto devido ao forte caráter ideológico, reacionário e imperialista das conclusões elaboradas pelos pensadores que se voltaram a analisar essa nova conjuntura. Independentemente dessas questões, ou talvez mesmo devido à controvérsia gerada por tais conclusões, essas análises influenciaram pesquisadores de todo o planeta nos anos vindouros.

Fora do contexto da Guerra Fria, diversos trabalhos de historiadores, sociólogos, psicólogos e demais cientistas sociais, se afastaram da parcialidade ideológica vista nas pesquisas pioneiras das décadas de 1960 e 1970, mas também, confirmaram alguns dos prognósticos proferidos pelos analistas citados anteriormente.

Nesse espaço, cabe avaliar dois trabalhos produzidos em campos um tanto opostos, mas que demonstram como parte das generalizações esboçadas ainda na década de 1960 estão em vias de tornar-se consenso nas Ciências Humanas. Usaremos esse campo teórico para qualificar o momento histórico da Revolução Microeletrônica, medir o impacto das transformações em curso e entender como tais conhecimentos técnicos se espraiaram no seio da sociedade capitalista na segunda metade do século XX:

da década de 1970, em diante, o mundo externo passou a intrometer-se mais indiretamente, mas também com mais força, nos laboratórios e salas de conferências, com a descoberta de que a tecnologia baseada na ciência, tendo seu poder multiplicado pela explosão da economia global, parecia na 
iminência de produzir mudanças fundamentais e talvez irreversíveis no planeta Terra.

No trecho apresentado, Hobsbawm (1995, p.531) introduz o tema que será desenvolvido quando analisa as grandes mudanças globais, ainda incipientes na década de 1970, mas que estavam em vias de gerar grandes transformações. Essas transformações são analisadas quando ao refletir sobre a segunda etapa do século XX, torna-se marcante o impacto da indústria química na natureza, da revolução na biologia molecular e engenharia genética e da íntima relação entre a economia e os laboratórios de alta tecnologia.

Para Hobsbawm, tais mudanças são paradigmáticas, principalmente porque implicam em um crescimento exponencial da capacidade humana de interferir em seu meio ambiente, de mudar e reconfigurar a vida em si mesma, de dinamizar e expandir o capitalismo a limites nunca sequer imaginados.

Da perspectiva das ciências naturais, particularmente do âmbito da geologia, os prognósticos mais inquietantes apresentados acima parecem em via de se confirmarem. Colin Waters, pesquisador do Serviço Geológico Britânico, coordenou um estudo que pretende comprovar que a taxa de transformação no meio ambiente, nos últimos sessenta anos, é tão elevada, que nesse momento faz sentido pensar que entramos em uma nova era geológica no planeta (WATERS, et al., 2016).

Essa era, nomeada como Antropoceno, é caracterizada pela proliferação de novos materiais, como o concreto e o alumínio em forma metálica, assim como a difusão do plástico e o aumento crescente das taxas de gás carbônico.

Para efeitos de comparação, de acordo com o estudo, tais mudanças são de magnitude igual ou superior a observadas no fim da última Era do Gelo, o Pleistoceno, ocorrido há 11,7 mil anos atrás. Ou seja, pensar em mudanças fundamentais e talvez irreversíveis na natureza não é um exagero retórico. De fato, a segunda década do século XX inaugurou um novo padrão de interação entre os seres humanos e a natureza.

Voltando para o ambiente sociocultural, a principal questão que Hobsbawm traz em sua análise é de que realmente não é prematuro citar a segunda metade do século 
XX como uma nova fase das relações sociais, culturais e econômicas. Conforme a análise desse historiador, o processo de evolução da economia capitalista encontrou nas novas possibilidades permitidas pela $P \& D$ e $C \& T$ fatores de dinamização e extensão das capacidades produtivas, comerciais e mesmo reordenação das demandas sociais.

Tais questões também são abordadas a partir de outros ângulos pelo sociólogo Manuel Castells. Conforme podemos conferir no trecho a seguir, para determinar as relações entre a ciência e tecnologia e a sociedade o autor primeiro propõe uma nova abordagem ao velho debate da História da Ciência entre as análises internalistas e externalistas. Se não apresenta uma alternativa definitiva para tais questões epistemológicas, ao menos articula um modelo explicativo extremamente útil na elaboração de explicações sobre as relações sociais, econômicas e culturais com a C\&T. Para elaborar tal discussão, parte das críticas que consideram tal proeminência da tecnologia como simples análises determinísticas propondo uma dialética social entremeando o processo. Posteriormente o autor identifica um núcleo pioneiro de onde muitas das inovações tecnológicas foram introduzidas intensivamente em nossa sociedade, desse núcleo, além da técnica baseada na tecnologia da informação, uma nova forma de produção industrial foi criada e introduzida no mundo; vejamos como essas questões são colocadas:

É claro que a tecnologia não determina a sociedade. Nem a sociedade escreve o curso da transformação tecnológica, uma vez que muitos fatores, inclusive criatividade e iniciativa empreendedora, intervêm no processo de descoberta científica, inovação tecnológica e aplicações sociais, de forma que o resultado final depende de um complexo padrão interativo. Na verdade, o dilema do determinismo tecnológico é, provavelmente um problema infundado, dada que a tecnologia é a sociedade, e a sociedade não pode ser entendida ou representada sem suas ferramentas tecnológicas. Assim, quando na década de 70 um novo paradigma tecnológico, organizado com base na tecnologia da informação, veio a ser constituído, principalmente nos Estados Unidos, foi um segmento específico da sociedade norte-americana, em interação com a economia global e a geopolítica mundial, que concretizou um novo estilo de produção, comunicação, gerenciamento e vida (CASTELLS, 1999, p.25). 
Temos clara a percepção de que qualquer incremento em uma técnica traz em si uma correspondente alteração na cultura, economia ou até mesmo nos vínculos sociais de uma determinada sociedade humana. Sabemos também que tais transformações ocorrem dentro de um complexo padrão interativo pautado pela dialética histórica das sociedades produtoras e receptoras dessas inovações. Portanto, entender a relação da C\&T com esse novo contexto social e econômico é um problema relacionado à capacidade de perceber a amplitude e velocidade das mudanças em curso.

Mudanças de grande escala motivadas por descobertas tecnológicas são vistas desde a aurora da humanidade, vide o enorme impacto causado pela Revolução Neolítica para as comunidades humanas primitivas, ou mesmo a influência transformadora dos processos da Revolução Industrial na sociedade, economia e cultura pré-industriais.

A grande novidade das relações entre a C\&T e a economia da segunda metade do Séc. XX está nas transformações geradas pela Revolução da Microeletrônica e a consequente estruturação de relações globais baseadas no informacionalismo. Para entender o alcance desse conceito é preciso considerar o efeito das tecnologias da informação na dinâmica, organização e desenvolvimento das economias capitalistas. Pela primeira vez na história humana foi possível utilizar um meio técnico que permitia a organização e hierarquização das demandas do capitalismo em tempo real entre os diversos ambientes econômicos e comunidades humanas do planeta. Ao criar o termo informacionalismo, Castells pretende deixar claro como essa circunstância é original em termos históricos além do caráter dialético dessas novas interações. Castells caracteriza bem esse momento no trecho a seguir:

\footnotetext{
Embora a economia informacional/global seja distinta da economia industrial, ela não se opõe a lógica dessa última. A primeira abrange a segunda mediante o aprofundamento tecnológico, incorporando conhecimentos e informação em todos os processos de produção material e distribuição, com base em um avanço gigantesco em alcance e escopo da esfera de circulação (CASTELLS, 1999, p. 110).
}

A Revolução da Microeletrônica possibilitou uma grande reordenação do sistema produtivo, incrementou a dinâmica das relações financeiras, redefiniu a forma, 
os locais e as relações de trabalho. Tamanha transformação só foi possível devido às novas formas de processamento e distribuição da informação ${ }^{4}$. Castells percebe com esse conceito a dimensão totalizadora e ao mesmo tempo flexível da tecnologia da informação incorporada aos objetivos capitalistas. Diferentes comunidades, empresas e sujeitos interagem com as redes informacionais. O informacionalismo, além de regular a produção, passou a ser um elemento fundamental nas relações pessoais, trabalhistas e culturais, com capacidade de levar as demandas do mercado a situações e lugares até então ainda não explorados.

Conforme Hobsbawm observa, esse novo arranjo cientifico e tecnológico levou o capitalismo a nova era de ganhos econômicos. Entretanto, tal processo não se limitou a transformar as relações econômicas das sociedades capitalistas, essas novas tecnologias, agregadas ao capital revigorado com as ferramentas do informacionalismo, permitiu transformações em larga escala na natureza e nas relações humanas. Paisagens e ecossistemas foram comprometidos de formas talvez irreversíveis, com as modernas técnicas de manipulação do DNA, colocou-se em questão a própria reconfiguração da vida e os limites éticos desse processo. Tais transformações moldaram novas relações de trabalho, além de produzir novas subjetividades e pertencimentos sociais.

No Brasil, país periférico ao capitalismo mundial e na década de 1970 ainda em desvantagem em relação ao desenvolvimento das principais inovações surgidas nos países centrais, o governo ditatorial também estava envolvido nessa conjuntura mundial mais ampla. Inclusive podemos dizer que a inserção brasileira no moderno sistema de C\&T e P\&D, baseado na microeletrônica e processamento de dados, ocorreu também devido à ajuda do considerável investimento a essas áreas destinado pelo regime militar. Nesse contexto, é clara a implementação de um projeto que visava instrumentalizar os conteúdos da C\&T em prol de um modelo desenvolvimentista, ou conforme o processo era denominado, em prol do Modelo Brasileiro de Desenvolvimento, bandeira que em última instância sustentava o regime. Veremos como parte da historiografia apresenta esse processo:

\footnotetext{
${ }^{4}$ Uma análise crítica da economia capitalista no contexto da crise do petróleo na década de 70 e a rápida absorção das ferramentas da tecnologia da informação pelo setor financeiro e suas graves consequências para economia global pode ser vista em: BRENNER, R. 2003. O Boom e a Bolha: Os EUA na Economia Mundial.
} 
Os governos militares investiram sobremaneira em capacitação científica e tecnológica em diversos setores, não só em construções civis, como estradas, aeroportos e usinas hidrelétricas, como também visando ao aperfeiçoamento de submarinos, aeronaves, mísseis, estando atentos aos desdobramentos da revolução eletrônica e à importância estratégica das telecomunicações, informática, inclusive em instituições próprias de ensino e pesquisa, seja do Exército, da Marinha ou da Aeronáutica (MOTOYAMA, 2004, p.321).

Seguindo a dinâmica histórica de sua época, as pressões do regime instalado e aproveitando a janela de oportunidades, amplos setores da academia científica brasileira estiveram envolvidos nesse processo de modernização e fomento à $C \& T$. O poder de atração dessas iniciativas para a academia não pode ser negado, Skidmore (1988, p.282) demonstra essa situação com clareza a seguir:

O governo Médici aumentou o orçamento para a educação superior, o que representou maior número de vagas nas universidades e contratação de mais professores. Houve por esse tempo também uma reversão no êxodo de talentos que ocorrera no período 1964-70, em contraste com a contínua hemorragia causada pelo autoritarismo do Chile, Uruguai e Argentina. Para os brasileiros dispostos a se conformar em viver em uma ditadura, as recompensas podiam ser grandes, não só para eles mas também para as suas instituições. Até os brasileiros desgostosos com o governo autoritário orgulhavam-se com a evidência de que o país estava realmente em franca ascensão. Quaisquer que fossem suas imperfeições políticas, o Brasil estava se aproximando do status internacional em ritmo mais rápido do que muitos ousaram esperar no início dos anos 60. Os sinais eram tranquilizadores.

Recuperando os debates que surgiram em torno de tais questões, podemos resgatar uma discussão realizada em 1972, quando em um simpósio sobre Política Científica no Instituto de Biofísica da Universidade Federal do Rio de Janeiro, sobre o estado e perspectivas almejadas para a C\&T do Brasil, uma série de conferencistas afirmou a necessidade de avanço da $\mathrm{P} \& \mathrm{D}$ conjuntamente com a C\&T no país ${ }^{5}$.

Nas inúmeras propostas expostas, é clara nessas análises a ligação entre Desenvolvimentismo e Tecnologia. Conforme números apurados e apresentados na

\footnotetext{
${ }^{5}$ As reflexões e análises do simpósio estão publicadas em: SOUZA, H.G. de. et al. 1972. Política Científica.
} 
ocasião, por Heitor G. de Souza, estavam previstos no "Programa de Metas e Bases para a Ação do Governo" para os anos de 1970/1973, Cr\$1470 milhões para programas na área científica e tecnológica, $\mathrm{Cr} \$ 2$ bilhões para indústrias elétricas e eletrônicas, $\mathrm{Cr} \$ 500$ milhões para indústria aeronáutica. Ou seja, existia um movimento do governo de disponibilizar verbas para o investimento em diversos setores da P\&D e C\&T. Também foram apresentados alguns números referentes ao estado da graduação e pós-graduação no Brasil até aquele momento. Considerando a Fapesp, Capes e CNPQ - de 1966 até 1971, foram concedidas 18.695 bolsas de estudo e pesquisa para acadêmicos desde a graduação até a pós-graduação. O autor também relata que naquele ano de 1970 matriculavam-se no país 16.000 pós-graduandos. A esperança era que esses pesquisadores trouxessem um necessário impulso ao defasado setor científico brasileiro e produzissem as condições necessárias para um desenvolvimento econômico e social de base tecnológica. Nesse mesmo artigo, o autor destaca os avanços significativos da Embraer e Embratel no encaminhamento dessas demandas.

$\mathrm{O}$ investimento e apoio federal dispensado não podem ser minimamente comparados à atuação das nações desenvolvidas, principalmente porque essas nações conseguiram elaborar uma gigantesca estrutura de C\&T e P\&D que, além de colocá-los na fronteira da exploração científica dessa nova era, também os permitiu dominar e monopolizar a produção industrial dessas novas tecnologias. Apesar do alcance limitado dos investimentos realizados no Brasil nesse contexto, se percebe dentro do planejamento estatal brasileiro uma visão estratégica no encaminhamento dessas novas demandas. $\mathrm{O}$ alcance e limite dessa atuação serão analisados adiante, nesse momento é importante observar que o Estado procurou através de ações afirmativas enfrentar as demandas e influxos dessa nova conjuntura histórica.

Delineado os contornos gerais da época e a relação estabelecida entre C\&T e o Desenvolvimento Econômico, cabe agora analisarmos o lugar do discurso econômico nesse processo. Afinal, como um pacto político-militar-social conseguiu mobilizar corações e mentes em nome do progresso e desenvolvimento da nação ao mesmo tempo em que perpetuava violências e atentados contra liberdades duramente conquistadas? Cremos encontrar parte da resposta na história da Teoria Econômica no Brasil e no uso 
político do Desenvolvimentismo, conceito amplo que foi mobilizado em diferentes contextos históricos.

A ideologia ligada ao Desenvolvimentismo como política de Estado, teorizada e aplicada como Política Econômica em alguns momentos na história do Brasil permitiu a cooptação de diversos setores sociais aos propósitos da industrialização e da modernização. Entendemos que o surgimento de um corpo técnico altamente treinado e com propostas de intervenção na economia serviu de sustentáculo para uma elite golpista que encontrou na doutrina desenvolvimentista e no mote da segurança nacional as bases para manutenção de seu poder. Porém, a estruturação do pensamento desenvolvimentista tem raízes muito mais profundas que a década de 1970. No próximo tópico faremos uma breve exposição desse processo com base na historiografia que procurou analisar o fenômeno desenvolvimentista no Brasil.

1.2 Planejamento e Teoria Econômica Desenvolvimentista no Brasil: A Emergência do Estado Desenvolvimentista e Industrializante

O desenvolvimentismo, como política de Estado foi inaugurado no Brasil durante a chamada "Era Vargas" -1930/1945. Tratava-se da implementação de uma ideologia nacionalista e industrializante amparada no pacto social com a burguesia industrial e levada adiante por uma elite técnico-burocrática responsável pela formulação de políticas econômicas que guiavam a construção do aparelho estatal interventor. Essa elite técnico-burocrática também estava envolvida no debate dos rumos que se delineavam com o desenvolvimento do projeto industrializante. Identificamos como os principais vetores dessa iniciativa a Comissão Nacional de Política Industrial Comercial - CNPIC e a Comissão de Planejamento Econômico.

Algumas das principais concepções sobre os rumos da política econômica e do debate oriundo desses projetos concentravam-se na atuação de Roberto Simonsen e Eugênio Gudin. Simonsen, inspirado pelo ferramental teórico da planificação econômica, vislumbrava a estruturação da sociedade e economia a partir de um corpo técnico-estatal que mobilizaria recursos para a superação das fragilidades produtivas nacionais; creditava ao impulso industrializante, promovido pelo capital estrangeiro e 
encetado pela burguesia industrial nacional, o caminho do desenvolvimento e crescimento econômico. Gudin demonstrava sua insatisfação com os rumos tomados pelo governo intervencionista ao propor um choque de liberalismo ortodoxo. $\mathrm{O}$ desenvolvimento nacional só seria possível a partir do livre-comércio e da valorização das vantagens comparativas nacionais, como o apoio a agricultura, por exemplo (BIELSCHOWSKY, 2000).

No final dos anos 40, o discurso desenvolvimentista recebeu o aporte teórico de um pensamento econômico estruturalista desenvolvido pela CEPAL - Comissão Econômica para a América Latina e o Caribe. Ligada a ONU, a CEPAL foi criada em 1948 com o intuito de conter a ameaça do avanço comunista nas Américas. A teoria econômica cepalina buscava a formulação de uma nova estrutura econômica para os países subdesenvolvidos - o objetivo dessa nova estrutura econômica era o de melhorar o padrão de vida, proporcionar a distribuição de renda e desenvolvimento via industrialização. $\mathrm{O}$ diálogo da teoria cepalina dá-se principalmente com as teorias de $\mathrm{W}$. W. Rostow, P. R. Rodan, R. Nurse, G. Haberler e J. Viner. Nesse diálogo, o trabalho de R. Prebisch se destaca por realizar uma análise crítica sobre a posição particular da economia dos países subdesenvolvidos na dinâmica capitalista.

Para Prebisch, existe uma relação centro-periferia entre as economias mundiais e tal relação condicionaria a forma das trocas econômicas entre os países. Por exemplo, a difusão desigual do progresso técnico e a deteriorização dos termos de troca subordinariam as economias dos países subdesenvolvidos a dos países desenvolvidos. Assim, o economista propõe a integração das economias subdesenvolvidas ao capitalismo a partir de planificação industrializante. As propostas de Prebisch conseguiram considerável repercussão no Brasil, com o destaque para a liderança de Celso Furtado. Inclusive o governo J.K. (1956-1961) desenvolveu uma política desenvolvimentista inspirada nas teorias cepalinas ${ }^{6}$.

\footnotetext{
${ }^{6}$ Breve bibliografia sobre o assunto: BIELSCHOWSKY, R. 2000. Pensamento Econômico Brasileiro: O Ciclo Ideológico do Desenvolvimentismo; RODRIGUES, O. 1981. Teoria do Subdesenvolvimento. FONSECA, P.C.D. 2000. As Origens e as Vertentes Formadoras do Pensamento Cepalino; MORAES, R.C.F. 1995. O Subdesenvolvimento e as Ideias da Cepal.
} 
Cabe lembrar que fora da abordagem plenamente estruturalista, o governo pós45 contou com a participação de economistas de perfil liberal, destacamos aqui a liderança de Gudin e Bulhões, outro nome importante foi o de Roberto Campos, que nos anos 50 caracterizava-se por um sincretismo econômico entre liberalismo/estruturalismo. Os debates econômicos nacionais contavam também com a colaboração marxista, mas essa nunca foi aplicada nas políticas econômicas de Estado devido seu caráter marginal. Podemos citar os trabalhos de N. W. Sodré e C. Prado Jr nessa esfera. Não colocamos no grupo marxista o pensamento de I. Rangel devido sua adaptação e leitura particular da teoria marxista. ${ }^{7}$

O golpe militar de 1964 traz consigo uma mudança das bases sociais que sustentavam as propostas desenvolvimentistas. De acordo com a análise de Bresser Pereira, a construção do Modelo Brasileiro de Desenvolvimento foi possível por intermédio de uma nova aliança entre o capital estrangeiro, a burguesia e os setores rurais de elite. $\mathrm{O}$ fim das ilusões quanto às possibilidades de um nacionalismo burguês industrializante contra o capital internacional abre espaço para o pragmatismo de um modelo de desenvolvimento que imaginava o progresso a partir da industrialização, mas afastava qualquer possibilidade distributivista. Os esforços em prol da doutrina de segurança nacional e a perspectiva da construção de um Brasil Potência tomaram conta do planejamento econômico a partir de então (PEREIRA, 1997).

Esse novo arranjo político, caracterizado pela conciliação da burguesia industrial com o setor agrário-exportador, aliado ao capital internacional e às multinacionais, rompia a relação com os setores trabalhistas que até então deram sustentação ao populismo e ao acordo de classes que regia as políticas de governo desde o Estado Novo. Cabe lembrar que essa mudança estrutural ocorreu com o pano de fundo das tensões e recrudescimento da Guerra Fria, e principalmente da Revolução Cubana, que em 1959 levaram à América Latina a radicalização política, tanto de direita quanto de esquerda, e ao conservadorismo.

\footnotetext{
7 Uma análise aprofundada sobre esse momento pode ser vista em: BIELSCHOWSKY, R. 2000. Pensamento Econômico Brasileiro: O Ciclo Ideológico do Desenvolvimentismo; MANTEGA, G. 1984. A Economia Política Brasileira.
} 
Sobre o Modelo Brasileiro de Desenvolvimento, cabe lembrar que o desenvolvimentismo imaginado e teorizado pelos economistas e tecnocratas aliados ao regime militar devia ocorrer como uma das chaves de manutenção da hegemonia capitalista no país. O período em que tratamos é marcado pela grande polarização política e ideológica entre o comunismo e capitalismo. Nos marcos teóricos da Doutrina de Segurança Nacional ${ }^{8}$ - pensamento elaborado pela Escola Superior de Guerra (ESG) que procurava discriminar e propor maneiras de se combater as eventuais ameaças a defesa nacional - para se conservar a estrutura tradicional da sociedade brasileira, cumpria aliar-se ao grande defensor dos ideais liberais e capitalistas do mundo ocidental, os Estados Unidos da América. A Doutrina de Segurança Nacional, além de ter o caráter defensivo, presumia a implementação de relações de poder e dominação que se estruturariam em todos os níveis da sociedade, inclusive na economia. De acordo com um dos difusores desse ideal, o Secretário de Defesa dos Estados Unidos, Robert McNamara (BRASIL, 1976, p.423):

\begin{abstract}
Numa sociedade que se está modernizando, Segurança significa Desenvolvimento. Segurança não é material militar, embora esse possa ser incluído no conceito; não é força militar, embora possa ser abrangida; não é atividade militar tradicional, embora possa envolvê-la. Segurança é Desenvolvimento e sem Desenvolvimento não pode haver Segurança.
\end{abstract}

O Modelo Brasileiro de Desenvolvimento seguia tais orientações. Para se cumprir o objetivo do desenvolvimento econômico planejava acelerar a industrialização e o crescimento de capital.

Dentro desse processo, alguns nomes se destacaram como mentores do planejamento e consecução da política econômica do governo Castello Branco (19641967). Otávio Gouveia Bulhões, Mário Henrique Simonsen e Roberto Campos elaboraram um documento (PAEG - Programa de Ação Econômica do Governo) no qual realizavam um diagnóstico da economia nacional e planejavam a recuperação

\footnotetext{
${ }^{8}$ Análises críticas sobre a Doutrina de Segurança Nacional e a atuação dos teóricos da Escola Superior de Guerra podem ser vistas em: BORGES, N. 2003. A Doutrina de Segurança Nacional e os Governos Militares; COMBLIN, J. 1978. A Ideologia da Segurança Nacional: O Poder Militar na América Latina; FERNANDES, A.S. 2009. A Reformulação da Doutrina de Segurança Nacional pela Escola Superior de Guerra no Brasil: A Geopolítica de Golbery do Couto e Silva.
} 
econômica para os anos posteriores. A partir de então iniciaram um amplo delineamento e reorganização da estrutura econômica nacional, como, por exemplo, a criação do Banco Central, a organização de uma nova política salarial e o controle das demandas sindicais com vistas a combater a crescente inflação. Além disso, planejaram a reorganização da estrutura fiscal do Estado, a negociação das dívidas externas e o reordenamento da relação entre União e Estados no controle dos gastos, etc ${ }^{9}$.

Tamanha intervenção só pode ser implementada devido aos amplos poderes concedidos a presidência pelo poder Legislativo, ao cerceamento a oposição (inclusive com prisões, torturas, cassação de mandatos políticos e aposentadorias compulsórias de funcionários do Estado ${ }^{10}$ e ao apoio indispensável do governo dos Estados Unidos, que atuou legitimando e garantindo a manutenção do regime militar através de investimentos diretos ao país, que no momento do golpe encontrava-se com suas linhas de crédito suspensas devido a ameaça de insolvência detectada pelos principais agências de crédito internacionais (FMI, Banco Mundial, etc) (SKIDMORE, 1988).

Em síntese, o programa econômico do governo Castello Branco se concentrou em viabilizar investimentos a partir da geração de poupança nacional (via contenção salarial e concentração de renda) e abertura para o capital externo. A melhoria da arrecadação e a redução dos gastos governamentais, aliados ao controle da inflação, pavimentaram o caminho da recuperação econômica do país. Esse ambiente de restauração da ordem econômica aliado ao afastamento do suposto perigo comunista tornou-se o grande fator de legitimação do Golpe de Estado, que então se encontrava institucionalizado.

O governo Médici (1969-1974) colhe dividendos do trabalho de base realizado pelo governo Castello Branco. É a época do "Milagre Econômico", conjuntura onde a

\footnotetext{
${ }^{9}$ Uma análise pormenorizada da Política Econômica do governo Castello Branco pode ser vista em SKIDMORE, 1988, p.69-89.

${ }^{10}$ Breve bibliografia sobre o autoritarismo e a repressão no Regime Militar:

ALVES, M. 2005. Estado e Oposição no Brasil (1964-1984); AQUINO, M. A. 1999. Censura, Imprensa, Estado Autoritário (1968-1978); FERREIRA, J. DELGADO, L. A. N. (orgs.) 2003. O Brasil Republicano: O Tempo da Ditadura: Regime Militar e Movimentos Sociais em Fins do Século XX; FICO, C. 2001. Como Eles Agiam. Os Subterrâneos da Ditadura Militar: Espionagem e Política; REZENDE, M. J 2000. A Ditadura Militar no Brasil: Repressão e Pretensão de Legitimidade (1964-1984).
} 
possibilidade do "Brasil Potência" se tornava cada vez mais nítida em um horizonte de médio prazo. Nesse momento a economia do Brasil era uma das que mais cresciam no mundo, apresentando resultados extremamente satisfatórios, como o crescimento médio do PIB de 10,9 por cento entre 1968 e 1974 (destaque para o poder da indústria nesses números, grande responsável pelo crescimento econômico desse momento).

Tal crescimento era sustentado através de incentivos tributários, manipulação do sistema financeiro para receber investimentos, redução do custo da mão de obra, etc. A equipe econômica do governo conseguiu a proeza de aumentar significativamente a base fiscal e, além disso, manter um relativo controle sobre a inflação. Aliada a essas ações, o governo anunciava contínuos saldos positivos na balança de pagamentos devido a crescente importação subsidiada, e utilizava-se do massivo ingresso de capital especulativo, que atraído pelas altas taxas de juros, sustentava os déficits acumulados por esse processo desenvolvimentista. O controle da política econômica desse momento coube a Delfim Netto, economista que já fazia parte do corpo técnico do governo desde o governo Costa e Silva (1967-1969) ${ }^{11}$.

Simonsen é o ministro responsável pela economia do governo Geisel (19741979), destaca-se nesse momento de declínio da pujança econômica o diálogo com o economista J.P. Reis Veloso. No plano da política econômica desse período vemos uma tentativa inicial de manter as taxas de crescimento do início da década de 1970 e construir o início da distribuição do capital acumulado (esse propósito é demonstrado através da criação de um novo Ministério da Previdência e Assistência Social, criado com o propósito de coordenar os dispersos e fragmentários programas sociais criados nos governos anteriores SKIDMORE, 1988).

Apesar dos planos otimistas, a conjuntura histórica não era favorável a altos voos. A crise do Petróleo vivenciada na economia mundial e existente desde os primeiros dias do novo governo afetou sobremaneira a balança de pagamentos nacional, com a decisão da OPEP (Organização dos Países Produtores de Petróleo) de triplicar o preço do barril de petróleo, o Brasil viu suas divisas rapidamente serem exauridas, pois

\footnotetext{
${ }^{11}$ Uma análise pormenorizada da Política Econômica do governo Médici pode ser vista em SKIDMORE, 1988 , p.276 a 282.
} 
naquele momento o país importava $80 \%$ de seu consumo desse produto. Em um ambiente econômico internacional marcado pela ameaça de recessão, o governo foi obrigado a recorrer a empréstimos cada vez mais elevados para manter seu padrão de crescimento. Inicialmente tal estratégia mostrou-se em parte bem sucedida, o crescimento próximo a $10 \%$ foi mantido no ano de 1974, mas esse estratagema não teria sucesso em um ambiente de persistente recessão.

As taxas de crescimento caiam paulatinamente ano a ano, em 1978, último ano do governo Geisel, o crescimento do PIB foi de aproximadamente 4,8\%. Além da expressiva queda desse indicador, o modelo de crescimento desse momento tinha evidente equivalência a de uma Vitória de Pirro, pois foi feito à custa de permanente endividamento. A dívida externa em 1978 estava na casa dos US\$43,5 bilhões, mais que o dobro do começo do mandato. Além do avanço da dívida, a inflação mostrava-se cada vez mais ameaçadora, estimada em aproximadamente $40,8 \%$ nesse último ano ${ }^{12}$.

O fim do Governo Militar, agora sobre o controle do general Figueiredo (19791985), e o período de maior crise econômica, teve a orientação de Delfim Netto. Ao assumir o comando da política econômica, Delfim Netto utilizou-se do otimismo para desenhar um futuro onde crescimento e controle da inflação se conjugavam com a premente e necessária distribuição de renda (SKIDMORE, 1988), entretanto o pragmatismo da situação real inaugurou a década de 1980 com grandes apreensões quanto às possibilidades econômicas do país.

Nenhuma das expectativas otimistas enunciadas por Delfim Netto foi alcançada no governo Figueiredo. Em 1979, o cartel petroleiro da OPEP novamente operou um choque no preço do petróleo, de maneira que economia mundial foi duramente golpeada. A dívida externa se tornou incontrolável no Brasil, ultrapassando a casa dos US\$100 bilhões. A inflação superou todos os prognósticos da equipe econômica, alcançando $230 \%$ ao longo dos seis anos do governo Figueiredo. Em 1982, em um cenário de profunda recessão, a independência econômica do regime militar capitula, o governo pede ajuda ao FMI. Uma análise esclarecedora desse ambiente de extrema

\footnotetext{
${ }^{12}$ Uma análise pormenorizada da evolução dos indicadores econômicos do governo Geisel pode ser vista em SKIDMORE, 1988, p.401 a 403. A análise sobre o custo da dívida externa para economia do período pode ser vista nas páginas 404 a 407.
} 
restrição econômica pode ser vista a seguir: “... a necessidade de evitar a inadimplência externa suplantou todas as demais metas econômicas. PIB, produção industrial, emprego, bem-estar social, tudo ficou subordinado à descoberta de dólares para pagar os juros da dívida" (SKIDMORE, 1988, p.458).

O FMI concede o financiamento exigindo o comprometimento com um plano de estabilização ortodoxo no qual as pretensões expansionistas são colocadas de lado. Se em 1985 Figueiredo conseguiu entregar o governo, para as mãos do presidente civil José Sarney, com as contas da balança de pagamento em relativa ordem, foi à custa do modelo desenvolvimentista que malogrou a olhos vistos. $\mathrm{O}$ resultado desse processo foi altamente custoso para a sociedade brasileira. O Brasil tornara-se um país com altas taxas de desemprego, a desigualdade social atingia níveis inaceitáveis, o parque industrial sofria o resultado de quase uma década de desaceleração econômica ${ }^{13}$.

Sobre a equipe técnica responsável pela política econômica do regime militar, cabe observar que a relativa continuidade dos quadros técnicos não produz continuidades na política econômica realizada, conforme percebemos, as políticas econômicas oscilaram de acordo com as conjunturas enfrentadas (MANTEGA, 1997). A atuação dos economistas encarregados do planejamento estratégico do governo mudou de maneira considerável nas diferentes circunstâncias enfrentadas, alternando a heterodoxia desenvolvimentista do Modelo Brasileiro de Desenvolvimento, característica dos momentos de bonança econômica, com a ortodoxia liberal pautada por cortes e diminuição do Estado nos períodos de recessão.

Procuramos nessa breve exposição recolocar o processo desenvolvimentista realizado pelos militares dentro do grande corpo histórico da Teoria Econômica Desenvolvimentista. Vimos que existem continuidades nesse processo, o desenvolvimentismo como teoria e ideologia modernizadora buscou em suas diferentes fases um modelo econômico de desenvolvimento baseado na industrialização e no planejamento econômico. Entretanto, esse processo histórico é permeado por descontinuidades particulares a cada contexto, essas descontinuidades são marcantes no

13 Uma análise pormenorizada da Política Econômica do governo Figueiredo pode ser vista em SKIDMORE, T. 1988, p. 415 a 491. 
Regime Militar devido ao novo arranjo político, e principalmente, ao novo pacto social que abriu mão do nacionalismo, vigente na fase de conciliação dos interesses de classe, para adotar os pressupostos da ideologia da segurança nacional como condutores do desenvolvimento brasileiro a partir do então chamado de Modelo Brasileiro de Desenvolvimento ${ }^{14}$.

Nessa fase de aliança ideológica com os Estados Unidos a economia brasileira abriu-se para o capital internacional e para as multinacionais. O país modernizou-se, o parque industrial diversificou-se, inclusive obtendo índices impressionantes na exportação de produtos industrializados e no acúmulo de capital nas mãos dos grandes empresários nacionais; entretanto o preço pago por essa aposta econômica mostrou-se muito caro, a concentração de renda, o desemprego e o endividamento externo alcançaram taxas inéditas.

Podemos agora avançar na análise da relação entre a C\&T e o planejamento econômico governamental, pois, a década de 60/70, além de ser o momento de emergência de um novo arranjo político/social, também viu o despontar de um Estado que agregou ao planejamento econômico outras esferas sociais além dos iniciais arranjos na produção e economia. Os planejadores econômicos do governo brasileiro perceberam que o estágio do desenvolvimento capitalista no Brasil exigia uma relação mais íntima entre a economia e a C\&T. Era preciso colocar o Brasil em contato com os laboratórios científicos e com as inovações que rapidamente transformavam estruturalmente as sociedades desenvolvidas. Analisaremos tal processo a seguir.

\subsection{Ciência e Tecnologia durante o Regime Militar: Possibilidades e Limites}

\section{do Modelo Brasileiro de Desenvolvimento}

Considerando a relação existente entre as políticas de C\&T e o planejamento econômico desenvolvimentista, a década de 1960 é o grande momento de viragem de perspectivas no Brasil. A partir dessa década, é clara a correlação existente entre esses

\footnotetext{
${ }^{14}$ Uma análise aprofundada das relações sociais e econômicas desse momento de transição entre as décadas de 1950 e 1960 pode ser vista em: PEREIRA, L. C. B. 1978. O Colapso de uma Aliança de Classes.
} 
núcleos (ciência e tecnologia e desenvolvimentismo), processos que até então eram elaborados de maneira quase que totalmente desvinculada. Conforme observação de parte da historiografia - “... dadas as características das etapas anteriores do processo brasileiro de desenvolvimento, as necessidades tecnológicas puderam ser atendidas independentemente de iniciativas governamentais mais explícitas." (GUIMARÃES, 1985, P.40). A mudança de patamar da economia do país exige uma nova abordagem do Estado e de criação e incentivo a políticas nacionais direcionadas.

Estabelecida a importância do progresso técnico para o desenvolvimento econômico, um dos debates centrais em questão era o das vantagens da importação e/ou vantagens do desenvolvimento de tecnologia e conhecimento técnico de matriz nacional. Os cientistas e a academia nacional desde pelo menos a década de 1930 insistiam na necessidade premente do desenvolvimento da pesquisa básica no país, universidades e instituições de pesquisa buscaram estruturar esse processo tentando conciliar suas demandas com a industrialização nacional, entretanto o imediatismo e a falta de visão de longo prazo impediram que o Estado desse a atenção necessária a esse campo (MOTOYAMA, 2004).

Junto a essas questões conjunturais, um debate ideológico no campo da economia impediu que as propostas da academia fossem vistas com maior atenção pelo corpo técnico-burocrático responsável pelo planejamento econômico do estado brasileiro.

Tal debate está circunscrito ao desenvolvimento das dinâmicas de produção e troca no capitalismo. Durante o desenrolar histórico, a dinâmica de acumulação capitalista concentrou os saberes técnicos e científicos nos países mais avançados. De acordo com a teoria liberal, os países periféricos obteriam os benefícios de tais conhecimentos através do comércio. Devido a posição hegemônica do campo liberal, por muito tempo a teoria das vantagens comparativas do comércio foi utilizada como resposta as demandas nacionalistas no campo do desenvolvimento da C\&T. Entretanto a própria estrutura do capitalismo e suas relações com a divisão internacional do trabalho condicionavam e perpetuavam uma dependência tecnológica dos países periféricos em relação aos países centrais. Essa análise não nega as vantagens da importação de 
tecnologia para o crescimento econômico, contudo, aliada a importação, faz-se necessário altos investimentos em P\&D. Esse é o entendimento que paulatinamente o Estado brasileiro começou a incorporar na década de 1960. Todavia tal análise nunca chegou a ser hegemônica nas definições das políticas de Estado para C\&T, muito ao contrário, o avanço da P\&D foi fragmentário, preso aos interesses sazonais e influências políticas de grupos ora ligados aos interesses nacionalistas, ora ligados às demandas externas.

Historicamente, ao observamos o processo de desenvolvimento tecnológico brasileiro, vemos que os setores ligados à exportação de tecnologia estrangeira foram as principais vozes na realização da política de C\&T no Brasil:

\footnotetext{
A um nível bastante geral, pode-se dizer que na composição das forças que regem o processo de industrialização brasileiro, o peso dos agentes privados (...) que têm seus interesses identificados com a importação irrestrita de tecnologia, foi dominante e até hoje é hegemônico.
}

Essa é a conclusão formada logo após a queda do regime militar por um grupo de pesquisa que pretendeu fazer um balanço desse período (GUIMARÃES, 1985. p.31) e que nos permite entender a inconstância e fragmentação do grupo nacionalista e das suas demandas na C\&T.

Partindo desses elementos, cabe agora apresentar como tais conteúdos foram mobilizados nos documentos que foram os vetores oficiais do planejamento estruturante do Modelo Brasileiro de Desenvolvimento.

Entendemos que alguns documentos oficiais formaram as linhas mestras da mobilização da C\&T e desenvolvimentismo no regime militar. Assim, nos concentraremos em apresentar as ideias e projetos presentes no Programa de Ação Econômica do Governo (PAEG), no Programa Estratégico de Desenvolvimento (PED), e nos I, II e III Planos Nacionais de Desenvolvimento (I PND, II PND, III PND). Usaremos novamente os resultados do balanço da política de C\&T no regime militar, trabalho publicado por Eduardo Augusto Guimarães, que servirá de guia para nossa 
exposição. Entendemos que esse trabalho sinteticamente conseguir traçar as principais questões que a subsequente historiografia de C\&T sistematizou ${ }^{15}$.

O contexto de crise política e econômica de 1964 impediu que os objetivos expressos no PAEG para C\&T fossem ambiciosos. A prioridade do governo estava no combate à inflação, portanto existia um ambiente economicamente restritivo para investimentos. Quando se volta para a C\&T (GUIMARÃES, 1985. p.42), os enunciados do PAEG:

restringem-se à política educacional voltada para a ampliação das oportunidades de acesso à educação, para a racionalização do emprego dos recursos disponíveis e para a adequação do ensino às necessidades técnicas e culturais da sociedade moderna.

Apesar de não existir espaço para apostas mais ambiciosas na C\&T e P\&D nacionais, fica implícita a aposta no recurso a fontes externas de tecnologia. Procuravase adquirir máquinas e equipamentos, assim como a tecnologia neles incorporada; incentivava-se a instalação de multinacionais e consequentemente a absorção dos conhecimentos presentes nessas unidades produtivas (VARGAS, 1994).

No Governo Costa e Silva, as disposições do Estado em relação à C\&T alteramse fundamentalmente (GUIMARÃES, 1985. p.45), conforme enunciado no PED:

o documento constitui um marco importante: não só as necessidades da economia brasileira na área de ciência e da tecnologia são apontadas e enfatizadas, mas ainda o PED propõe, pela primeira vez de forma explícita e sistematizada uma política científica e tecnológica para o país... tinha-se em vista tanto a necessidade de acelerar o ritmo de incorporação de tecnologia ao sistema produtivo, quanto a importância de empreender esforço próprio de pesquisa, já que, nas palavras do próprio PED, 'a tecnologia importada nem sempre é adequada a constelações de fatores do país importador' e que 'a própria absorção de tecnologia requer, à medida que a indústria se integra, pesquisas e desenvolvimentos locais.

\footnotetext{
15 Uma discussão aprofundada sobre tais questões pode ser verificada em: MOTOYAMA, S. 1999. Fapesp: Uma história da política científica e tecnológica; Idem. 2004. Prelúdio para uma História: Ciência e Tecnologia no Brasil;VARGAS, M. (Org.) 1994. História da Técnica e da Tecnologia no Brasil.
} 
Para realizar tais objetivos o Conselho Nacional de Pesquisas (CNPq) coordenaria o Plano Básico de Pesquisa Científica e Tecnológica, procurando a partir de incentivos, financiamentos e reorganização do sistema de pesquisa nacional, desenvolver programas e projetos prioritários para o regime militar na área de C\&T. O governo planejava também fortalecer financeiramente o $\mathrm{CNPq}$, através da criação de um Fundo Nacional de Desenvolvimento Científico e Tecnológico (FUNTEC) pelo BNDE. Além disso, o PED apontava quais seriam os projetos principais que receberiam apoio do CNPq, da FUNTEC, da Comissão Nacional de Atividades Espaciais (CNAE) e do Conselho Nacional de Energia Nuclear (CNEN). Por sua abrangência e pioneirismo, as linhas de ação do governo em C\&T enunciadas pelo PED reapareceram nos próximos documentos oficiais.

Em um momento de pujança econômica, e com a elaboração de metas ambiciosas para o desenvolvimento nacional, o I PND ao tratar de políticas de C\&T refina os procedimentos expostos no PED - por exemplo, abordando realisticamente em um tom fora do otimismo excessivo exposto no PED quanto às possibilidades do investimento em $C \& T$ e $P \& D$ para o desenvolvimento econômico da nação - além disso, o governo pretende aprofundar as relações produtivas e interações com o campo tecnológico (GUIMARÃES, 1985. p.49-50):

O programa de ciência e tecnologia previsto para o triênio 1972-1974 compreendia: ordenar e acelerar a ação do governo na área, principalmente mediante a operação do sistema financeiro de apoio ao desenvolvimento tecnológico e a coordenação da atuação das principais instituições governamentais de pesquisa através de um Plano Básico de Des envolvimento Científico e Tecnológico; desenvolver áreas tecnológicas prioritárias (energia nuclear, pesquisa espacial, oceanografia, indústrias intensivas em tecnologia, tecnologia de infraestrutura e pesquisa agrícola); fortalecer a infraestrutura tecnológica e a capacidade de inovação da empresa nacional, privada e pública; acelerar a transferência de tecnologia e integrar indústria-pesquisa e universidade.

Devido à ousadia do projeto, fazia-se necessário uma perfeita sintonia entre a equipe econômica e a consecução dos projetos de C\&T. Entretanto, o grande projeto formulado pelo I PND voltava-se para a manutenção das altas taxas de crescimento. 
Buscando-se esse objetivo, e seguindo a tradição de incorporação de tecnologia estrangeira via importação, resolvia-se tal questão. Assim, medidas que dependiam apenas do Ministério do Planejamento e de outras instituições governamentais ligadas a C\&T conseguiam ser implementadas, outras propostas que dependiam da intervenção do Ministério da Fazenda não foram levadas adiante devido à visão pragmática das lideranças no controle da política econômica.

A análise geral do II PND demonstra uma das principais preocupações do governo dos anos 70, trata-se da questão energética no contexto da crise do petróleo. $\mathrm{O}$ governo procura incentivar o programa nuclear, também busca o aumento da produção nacional de petróleo e apoia pesquisas voltadas para o desenvolvimento de combustíveis alternativos. Além dessas medidas conjunturais, o desenvolvimento econômico nacional pedia a prioridade de investimento tecnológico em alguns setores da economia que despontavam, conforme a análise de Guimarães (1985, p.58):

seria conferida prioridade ao desenvolvimento tecnológico de setores industriais básicos e de alto conteúdo tecnológico, notadamente a indústria eletrônica (em particular, a de computadores), de bens de capital, química e petroquímica, siderúrgica e metalúrgica e aeronáutica.

Entretanto, algumas questões estruturais (além da conjuntura internacional de crise) impediam o sucesso efetivo de tais planos, principalmente (GUIMARÃES, 1985. p.59-60):

\footnotetext{
a incapacidade da política governamental em reconhecer que as transformações pretendidas na estrutura produtiva e, em particular, uma maior participação e controle do capital nacional sobre o processo de expansão industrial requeriam modificações significativas nos padrões vigentes de financiamento e dinâmica de acumulação.
}

O período de vigência do III PND corresponde ao momento de desmontagem de qualquer pretensão desenvolvimentista. A crise econômica nacional avançava a passos largos, o governo procurava soluções para questões pragmáticas, de modo que a C\&T novamente foi relegada ao ostracismo nas políticas nacionais. Observamos tal conjuntura quando se verifica que o III PND reserva apenas uma página a ciência e tecnologia (GUIMARÃES, 1985). O lugar da C\&T no regime militar fica claro nesse 
processo, a lógica que mobilizou a agregação das questões científicas aos conteúdos desenvolvimentistas tornou impossível qualquer elaboração mais complexa dessas questões fora dos limites estreitos impostos pelo Modelo Brasileiro de Desenvolvimento e sua busca por crescimento dos índices econômicos.

Quando a historiografia de História da Ciência aborda os anos do regime militar se reconhece que apesar dos desmandos e cerceamentos a que estavam submetidas à comunidade acadêmica nacional alguns períodos podem ser classificados como extremamente profícuos do ponto de vista do fomento a pesquisa tecnológica. A materialização dos planos presentes nos documentos oficiais permitiu o estabelecimento regular da pesquisa científica no Brasil, estrutura que até então era organizada de maneira fragmentária e dispersa no território.

Elencar todo o complexo científico e tecnológico constituído nesse processo seria exaustivo para o espaço que temos disponível, entretanto citaremos algumas áreas e setores para onde a atenção do governo voltou-se.

A pesquisa tecnológica na área de engenharia foi incrementada com o apoio a institutos no Rio de Janeiro e em São Paulo, além da criação, transformação e modernização das instituições tecnológicas de norte a sul do Brasil. Nessa área também se estruturou órgãos burocráticos federais e estaduais de apoio a tais instituições. Para desenvolver os grandes projetos governamentais, criaram-se grandes estatais federais que também se tornaram centros de P\&D. Além disso, instituições de ensino e pesquisa tecnológica foram criadas, tais instituições surgiram tanto de caráter público, quanto privado (Exemplo: as Fatecs, a Ceeteps, a Inatel e diversas outras).

Articulando e estruturando essas diversas iniciativas, o regime militar regulamentou e reordenou os cursos de Pós-Graduação e Ensino Superior, movimento que se deu a partir de 1963 e teve como principal consequência um grande crescimento das universidades brasileiras (MOTOYAMA, 2004).

Quanto aos aspectos referentes ao projeto de organização do modelo educacional brasileiro, parte dos trabalhos de História sobre as reformas no ensino superior e no ensino médio entendem que tais reformas "corresponderam a um esforço dos grupos 
coligados no chamado pacto político autoritário em alinhar o sistema educacional pelo fio condutor da ideologia do desenvolvimento com segurança” (GUIRALDELLI, 1992. p.69).

O resultado de tal esforço pode ser quantificado ao fim do regime militar. Em 1985, o Brasil se tornara o maior sistema de C\&T da América Latina, com 52.863 pesquisadores, 11.000 doutores e 3.5 milhões de pessoas portadoras de diploma superior (MOTOYAMA, 2004).

Entretanto, apesar dos avanços vistos na graduação e pós-graduação, algumas obras que analisam esse processo chegam à conclusão de que o desenvolvimento tecnológico brasileiro assentava-se em bases afastadas de qualquer projeto social minimamente ambicioso. Conforme uma das análises sobre esse tema o (MOTOYAMA, 2004. p.360), o:

\footnotetext{
desenvolvimento tecnológico mais ligado à diversificação de bens de consumo duráveis do que à mudança das estruturas produtivas, propiciava um maior distanciamento entre as classes baixa e alta da população. Em consequência, entre 1960 e 1980 houve um forte processo de concentração de renda no país. Os $50 \%$ mais pobres, que controlavam $17,4 \%$ da renda pessoal no Brasil em 1960, o que já era muito pouco, passaram a controlar 12,6\% em 1980. Em compensação, os $10 \%$ mais ricos, que controlavam $39,6 \%$ da renda em 1960, passaram a controlar 46,7\% em 1970, e 50,9\% em 1980.
}

Cabe agora lembrarmos que o Modelo Brasileiro de Desenvolvimento não se materializou sem oposição. A crítica ao projeto e aos resultados desse processo foi uma constante durante todo o regime militar. Tal pensamento crítico buscou na realidade nacional bases para uma sólida contraposição aos rumos que estavam sendo tomados, diversos intelectuais que analisaram o período demonstraram as contradições existentes entre as propostas colocadas em prática pelos militares e a realidade nacional.

Logo nos primeiros anos do regime militar, em 1966, uma resposta crítica fundada no marxismo buscou reinterpretar as condições nacionais, expondo com clareza quais transformações estruturais eram necessárias no país, transformações das quais o governo instituído se furtava a realizar, estamos falando do livro "A Revolução 
Brasileira", de Caio Prado Jr. (1966). Autor que teve um grande impacto nas interpretações das condições históricas nacionais, seu trabalho tanto abriu novos horizontes de atuação para esquerda brasileira, quanto produziu uma análise que frutificou em novas interpretações históricas do período republicano e colonial ${ }^{16}$.

Ainda no marxismo o campo de análise trotskista/leninista ganhou impulso com a análise de André Gunder Frank, com o artigo "Desenvolvimento do Subdensevolvimento (1966) e uma sequência de livros após a publicação de "Capitalism and Underdevelopment in Latin America" (1969). Pertencentes ao campo do troskismo/leninismo surgem às análises de Ruy Mauro Marini (1969) e Theotônio dos Santos (1967). Não podemos deixar de citar ainda entre os marxistas a obra do professor Florestan Fernandes (1968, 1974), independente, produziu uma obra de fôlego onde procurou retratar a complexa estrutura social brasileira.

Deslocado da análise marxista, um novo campo teórico crítico ficaria conhecido como a "teoria da dependência". Um dos trabalhos fundamentais para esse campo teórico é a obra de Cardoso e Faletto (1970), trabalho que circulou clandestinamente em cópias mimeografadas em 1967, e teria a primeira edição impressa em 1970, trata-se de "Dependência e Desenvolvimento na América Latina". Grosso modo, a teoria da dependência procurou demonstrar como as condições econômicas externas, que condicionam a dependência, estão intimamente relacionadas às estruturas sociais internas. Dentro dessa teoria alguns trabalhos procuraram definir novos modelos de desenvolvimento, por exemplo, a obra de Maria Conceição Tavares e José Serra (1971), às contribuições de Antônio Barros de Castro (1969), ou os trabalhos de Celso Furtado $^{17}$.

\footnotetext{
${ }^{16}$ Inúmeras são análises que partiram de proposições de Caio Prado, citaremos a seguir algumas obras a título de ilustração: João, J.M.C 1975. O Capítalismo Tardio; FAUSTO, B. 1972. A Revolução de 1930: História e Historiografia; OLIVEIRA, F. 1972. Crítica à Razão Dualista ; NOVAES, F. 1979. "Portugal e Brasil na Crise do Antigo Sistema Colonial (1777-1808); MARTINS, L. 1979. Pouvoir et Développement Economique.

17 FURTADO, C. 1966. Subdesenvolvimento e Estagnação na América Latina; Idem, 1967. Teoria e Política do Desenvolvimento Econômico; Idem, 1972. Análise do Modelo Brasileiro; Idem, 1974. O Mito do Desenvolvimento Econômico. Idem, 1981. O Brasil Pós-Milagre.
} 
O campo teórico da "nova dependência" ganharia grande repercussão na década de 1970, o debate e crítica ao modelo desenvolvimentista implementado frutificou tanto no Brasil quanto na América Latina.

Para não fugirmos demasiado de nossos objetivos ${ }^{18}$, vamos nos concentrar em explicitar alguns elementos de uma crítica que, em particular, consideramos como central para a avaliação do padrão de desenvolvimento em curso nesta década em que o ufanismo nacionalista vivia o início da longa ressaca econômica no pós- "milagre brasileiro". Estamos falando de um pequeno livro onde o economista Celso Furtado define os limites e as impossibilidades inerentes à busca pelo desenvolvimento econômico, além demonstrar o caráter de aposta desmedida nos progressos da C\&T. Vemos parte dessa análise a seguir (FURTADO, 1974. p.08):

Com o campo de visão delimitado por essa ideia diretora (o desenvolvimento econômico), os economistas pass aram a dedicar o melhor de sua imaginação a conceber complexos esquemas do processo de acumulação do capital no qual o impulso dinâmico é dado pelo progresso tecnológico, enteléquia concebida fora de qualquer contexto social. Pouca ou nenhuma atenção foi dada às consequências, no plano cultural, de um crescimento exponencial do estoque de capital. As grandes metrópoles modernas, com seu ar irrespirável, crescente criminalidade, deteriorização dos serviços públicos, fuga da juventude na anticultura, surgiram como um pesadelo no sonho de progresso linear em que se embalavam os teóricos do crescimento. Menos atenção ainda se havia dado ao impacto no meio físico de um sistema de decisões cujos objetivos últimos são satisfazer interesses privados.

Em poucas linhas o autor desmonta toda uma concepção de desenvolvimento ancorada no substrato mítico do progresso tecnológico como grande emancipador da humanidade, apresentando os sacrifícios ecológicos e sociais exigidos por essa alternativa.

Recuperando a primeira parte do capítulo no qual vimos à origem das análises sobre o progresso tecnológico e o fortalecimento do poder do Estado e relacionando

\footnotetext{
${ }^{18}$ Uma análise crítica do percurso intelectual de cada uma dessas diferentes interpretações da economia e sociedade brasileira no contexto do Regime Militar pode ser vista em: PEREIRA, L.C.B. 1997. Interpretações sobre o Brasil.
} 
esse contexto com o trecho destacado acima, percebemos que Celso Furtado aponta os desdobramentos da busca desenfreada por esse tipo de desenvolvimento. Sua análise está dialogando intimamente com o momento histórico vivido.

Ou seja, Furtado coloca questões aos economistas desenvolvimentistas, mas também faz a interlocução com o campo teórico que investigou a Revolução da Microeletrônica e indiretamente permitiu a construção de utopias tecnológicas muitas vezes dissociadas da realidade material vivenciada. Esse diálogo pode ser remetido ao trabalho de Daniel Bell e Zbigniew Brzezinski, que produziram obras que tem por abordagem comum a construção de postulados sobre a sociedade pós-industrial, ou tecnectrônica, dissociadas das contradições inerentes à sociedade capitalista. Furtado lembra com sua análise que pensar a construção do desenvolvimento apenas pela via das potencialidades da $\mathrm{P} \& \mathrm{D}$ e $\mathrm{C} \& \mathrm{~T}$, é conceber o progresso tecnológico como um processo autossuficiente desvinculado da história e sociedade no qual ele está inserido.

A partir dessa conjuntura é que Celso Furtado desenvolve sua análise crítica aos resultados da busca do acúmulo de capital dissociada de objetivos culturais, sociais e ecológicos claros. A simples acumulação de capital e a construção de meios tecnológicos avançados não se traduzem no plano social no encaminhamento das demandas da desigualdade, na solução dos problemas culturais e ecológicos da sociedade, que dentro desse contexto, tende a se cindir cada vez mais no conflito entre o capital e o trabalho.

Ao abordar a política de desenvolvimento nacional, Furtado ressalta: "A política de desenvolvimento orientada para satisfazer altos níveis de consumo de uma pequena minoria da população... tende a agravar desigualdades sociais e elevar o custo social de um sistema econômico." (FURTADO, 1974. p.57). Nesse trecho o autor expõe com clareza os limites enfrentados pelo Modelo Brasileiro de Desenvolvimento. O entendimento que priorizava a necessidade de "crescimento do bolo" para posterior distribuição começava a dar sinais de desgaste. Os custos sociais cresciam, trazendo como resultado o aprofundamento da desigualdade social. A distribuição de renda tornava-se cada vez mais um dos grandes problemas estruturais da sociedade brasileira. 
Além da concentração de renda descomedida, o próprio processo de modernização das estruturas científicas e industriais começava a fazer água, pois conforme algumas análises de pesquisadores desse processo, a aderência à "tecnologia de consumo" dos países centrais, além dos custos sociais, produziu também distorções sobre tecnologias importantes para o pleno desenvolvimento econômico do país. Por exemplo, nas tecnologias de produção e de projetamento, a exigência de produtos similares aos de economias avançadas reforçou a dependência tecnológica nacional, pois essa se relegou a fundamentalmente replicar técnicas e padrões de projetamento estrangeiros (GUIMARÃES, 1985. p.34).

Nas horas finais do Modelo Brasileiro de Desenvolvimento, o ideal de modernização e desenvolvimento econômico se apresentava desacreditado e rejeitado por seus apoiadores de primeira hora, a balança apresentava saldos negativos expressivos, seja no campo econômico e social, seja nas áreas complementares às essas esferas. A modernização realmente efetivada na área $C \& T$ e da $P \& D$ deu-se dentro das contradições de um modelo que claramente subordinou a atividade científica e acadêmica às demandas do crescimento econômico.

\section{Capítulo 2 - PRAGMATISMO E UTOPIA: AS BASES HISTÓRICAS DO POLO TECNOLÓGICO DE CAMPINAS}

\subsection{Campinas: Frente Pioneira de expansão colonial, o ciclo do café e a} modemização industrial

O objetivo central desta dissertação é apresentar da maneira mais ampla possível os fatores que estruturalmente e conjunturalmente formataram a materialização do polo tecnológico de Campinas. Partimos do pressuposto de que para avaliar a atuação econômica e social de um polo tecnológico é preciso entender os objetivos históricos que esses empreendimentos buscaram realizar (CASTELLS, 1994). Assim, para cumprir esse propósito, é necessário construir uma narrativa histórica que tenha em seu arcabouço a sobreposição dos diversos elementos formadores desse evento, procurando 
unir a narrativa dos fatos o diálogo constante entre as múltiplas camadas da realidade histórica.

Partindo dessa proposição, aventamos a hipótese de que para compreendermos como as forças sociais e econômicas atuaram na construção e materialização do polo tecnológico de Campinas é preciso ter em perspectiva que esse processo está associado à dinâmica de acumulação capitalista e diversificação econômica da região com a consequente transformação da estrutura social e urbana da cidade. Aliado a esse processo, também entendemos que foi determinante a atuação do governo federal, que ao identificar as potencialidades presentes em Campinas, procurou mobilizar as competências locais no sentido de realizar alguns dos objetivos presentes no Modelo Brasileiro de Desenvolvimento.

Para resgatarmos as origens desses eventos, apresentaremos uma breve análise do desenvolvimento histórico local, procurando apontar as estruturas sociais e econômicas que possibilitaram a acumulação capitalista e a diversificação econômica e social associada ao crescimento urbano e industrial. Apontaremos também como esse processo permitiu o surgimento de instituições de ensino e pesquisa articuladas com as necessidades locais e como a partir dessa estrutura foi possível planejar o desenvolvimento de um polo industrial centrado no uso intensivo da tecnologia.

A história da modernização das forças produtivas da cidade de Campinas tem uma ampla bibliografia que será apresentada adiante, partimos da perspectiva de que a modernização industrial da região só foi possível através do acúmulo de capital e transformação das estruturas locais proporcionadas pela agricultura cafeeira. Os investimentos necessários para o surgimento da industrialização só seria possível "num momento de auge exportador, em que a rentabilidade do capital cafeeiro há de ter alcançado níveis verdadeiramente extraordinários" (MELLO, 1991, p.100).

Portanto, cabe nesse momento descrever como foi possível a instalação do complexo produtivo agrário baseado na cultura cafeeira. A origem dessa forma de exploração econômica está nos primórdios da ocupação colonial dessa região. É a partir da descrição desse processo que iniciaremos nossa análise. 
A colonização da região de Campinas começou por volta de 1722. Em 1774 esse povoado foi reconhecido pelo governo colonial e denominado como Freguesia das Campinas do Mato Grosso de Jundiaí (MATOS, 1988). Essa região passou a atrair a atenção de iniciativas colonizadoras, pois nessa região havia um dos entrepostos do Caminho das Goiases, rota que penetrava no Oeste paulista e se aprofundava no sertão profundo de Goiás (IBGE, 1952).

Frente pioneira do expansionismo bandeirante, identificamos no momento do povoamento de Campinas os elementos mais tradicionais da colonização do planalto paulista. Entre esses elementos podemos citar a iniciativa criadora dos bandeirantes que procuravam superar sua pobreza material embrenhando-se nas selvas em busca das riquezas presentes no interior.

Também é marcante nessa fase a rudeza dos costumes, a precariedade das instalações urbanas e das vias de acesso, que muitas das vezes eram simples picadas quase indistinguíveis no meio da mata. É farta a documentação que demonstra que a ocupação do interior, realizada pela atividade bandeirante, foi em grande parte possível graças à assimilação dos costumes e conhecimentos indígenas. Vilas e povoados desenvolvem-se em relação íntima com os elementos da civilização aborígene, podemos elencar entre esses elementos a alimentação, as trilhas e caminhos percorridos e muito dos usos e costumes sociais. Tais influxos culturais atuaram formatando e remodelando os elementos da cultura europeia transmitida pelo colonizador português (HOLANDA, 1957).

A ocupação do Oeste paulista em grande parte deve-se a iniciativa do bandeirante Bartolomeu Bueno da Silva, o Anhanguera. Nessas áreas pioneiras, a estrutura social e econômica inicial é altamente carregada dos sinais mais típicos das sociedades americanas fronteiriças, ou seja, a miscigenação, a precariedade da vida material e a já citada predominância dos elementos indígenas na cultura e nos hábitos sociais.

Interessante observar que o capital acumulado com as bandeiras paulistas e o comércio encetado pelos tropeiros foi investido nas primeiras atividades econômicas agrícolas desenvolvidas na região de Campinas. Consolidada a produção agrária, o 
grupo de donos de terras ganharia destaque na sociedade paulista nos fins do século XIX como os futuros Barões do Café (SAES, 1986).

A etapa econômica preliminar ligada às atividades de subsistência logo foi superada e as terras da cidade passaram a comportar uma crescente atividade agrícola voltada ao cultivo da cana-de-açúcar, tal produção ocupou um espaço cada vez mais considerável no conjunto das atividades desenvolvidas durante o término do século XVIII e início do século XIX. Além da importância quantitativa, a produção açucareira também é a grande responsável pela interligação da economia local com o grande sistema colonial. Assim, a produção agrícola de Campinas passou a fazer parte das grandes rotas de comércio que tinham por destino a economia europeia. Dessa maneira, a cultura canavieira trouxe consigo elementos de dinamização econômica, de diversificação social associada ao crescimento urbano, e a centralização da cidade como eixo de destaque da rede de caminhos que interligavam o Centro Oeste as rotas que percorrem o planalto paulista, atravessando a cidade de São Paulo e concluindo o percurso no porto de Santos (SEMEGHINI, 1991).

Ainda sobre as vias de comunicação que interligam a capital da província à região de Campinas, é interessante observar que na maior parte dos casos tais caminhos já existiam antes mesmo da colonização europeia. Os grupos indígenas que viviam no interior paulista deixaram uma extensa rede de caminhos que na maior parte das vezes simplesmente passaram a ser utilizadas pelos colonos recém-chegados. Essa é a conclusão das pesquisas que se debruçaram sobre esse tema, inclusive vale a menção de um trecho do livro Caminhos e Fronteiras sobre essa questão:

Da existência efetiva dessas vias, já com caráter mais ou menos permanente antes de iniciar-se a colonização nada autoriza a duvidar. E ainda hoje, o traçado de muitas das estradas de ferro parece concordar, no essencial, com os velhos caminhos de índios e bandeirantes, sinal de que sua localização não seria caprichosa (HOLANDA, 1957, p.56).

Curiosamente, nestas estradas extremamente rústicas talvez esteja uma das estruturas civilizacionais de mais longa duração existente em terras paulistas. Como observa Sérgio Buarque de Holanda, os caminhos percorridos pelos indígenas serviram 
aos primeiros colonizadores europeus da região, posteriormente esses mesmos caminhos serviram de referência geográfica para a instalação das ferrovias, tais ferrovias surgiram em um processo de modernização do transporte que inaugurou a etapa das ferrovias e locomotivas a vapor para escoar a produção cafeeira produzida no interior para os portos no litoral. Ao lado dessas ferrovias, já no século $\mathrm{XX}$, surgiram as modernas estradas paulistas. Um viajante atento consegue perceber que estradas como a Rodovia Anhanguera, a Rodovia dos Bandeirantes, a Rodovia Governador Adhemar Pereira de Barros, etc, seguem o percurso das antigas estradas de ferro paulistas em grande parte de sua extensão. Temos nesse contexto uma longa continuidade histórica. Os caminhos indígenas formaram uma estrutura de longuíssima duração que até hoje norteia a malha viária dessa parte do Estado de São Paulo.

O perfil do trabalho desenvolvido na região não escapa da lógica do escravismo estabelecido desde a colonização e ainda instituído como a principal forma de trabalho durante o Império. Nesse quesito, Campinas se destaca no conjunto das vilas, aldeamentos e cidades do interior paulista devido a grande quantidade de trabalhadores escravizados alocados nos canaviais. Tal disposição trouxe uma importante vantagem econômica para a cidade no momento de restrição ao tráfico negreiro. A acumulação da mão de obra compulsória permitiu consideráveis ganhos na posterior fase econômica do município, a produção cafeeira. O estoque de mão de obra era tão grande que, em 1873, Campinas possuía 13.412 escravos, em um universo de 74.606 trabalhadores compulsórios da província de São Paulo, portanto $18 \%$ dos escravos da província se concentravam nessa região (BADARÓ, 1996). Definitivamente, os Barões do Café campineiros puderam concorrer em termos extremamente favoráveis com outras áreas menos favorecidas do ponto de vista da mão de obra, como o Vale do Paraíba.

A transição da cultura agrícola marcada predominantemente pela produção de cana-de-açúcar para a posterior cultura cafeeira foi determinada principalmente pelo esgotamento econômico das fazendas situadas na região do Vale do Paraíba e o subsequente deslocamento geográfico do cultivo do café para região do Oeste Paulista. 
$\mathrm{Na}$ primeira metade do século XIX, a área denominada como Oeste Paulista correspondia às vizinhanças de Bragança Paulista, Campinas, Piracicaba e Sorocaba ${ }^{19}$.

Já nas primeiras décadas de produção intensiva, a região Oeste mostrou-se extremamente eficiente no cultivo do café. A historiografia que analisou as décadas de 1850 e 1860 identificou que essas novas regiões possuíam clima e topografia favoráveis, além de terras férteis disponíveis para implantação dessa nova lavoura. Soma-se a essas vantagens a transferência de conhecimento do plantio, que em alguma medida migrou para essa nova zona de expansão. Outro fator importante que facilitou a introdução dessa nova cultura agrícola está ligado à disponibilidade de mão de obra, seja através do trabalho servil, conforme já citado, e mesmo do trabalho livre, que se tornava cada vez mais expressivo com o advento da imigração, além da presença numericamente significativa de trabalhadores que se fixavam na região através de movimentos de migração interna (SEMEGUINI, 1991).

A crescente produção cafeeira na cidade de Campinas proporcionou grande desenvolvimento econômico, urbano e social para a cidade. A acanhada povoação agrícola do século XVIII, com a introdução e desenvolvimento da cultura cafeeira, recebeu o prestígio e a importância de principal centro exportador da província de São Paulo. De 1860 a 1870 concorre-se em termos de igualdade com a então estagnada cafeicultura do Vale do Paraíba, e entre os anos de 1870 a 1886, Campinas passou a ser conhecida como a "capital agrícola" da província devido aos crescentes índices de produtividade das fazendas da região (CANO, 1977).

Para fins de comparação, é interessante observar a avaliação de uma das principais obras de análise sobre esse período (SEMEGUINI, 1991, p.51): "O fluxo de renda gerado na lavoura desenvolvera na cidade uma estrutura de serviços e um aparato cultural que em São Paulo só encontrava paralelo na capital". Colégios, teatros,

\footnotetext{
${ }^{19}$ Os motivos do esgotamento econômico da região do Vale do Paraíba, as características das diferentes fases de exploração da cultura cafeeira no Oeste Paulista e os múltiplos resultados desse processo são explorados por uma extensa historiografia, citamos em destaque a obra de CANO, W. 1977. Raízes da concentração industrial em São Paulo; MELLO, J. 1975. O Capitalismo tardio; COSTA E SILVA, S. 1982. Roteiro do Café e outros ensaios; MATOS, O. 1985. Café e ferrovias; OLIVEIRA, M. 1987. Questões demográficas no período cafeeiro em São Paulo; RICCI, M. 1982. Campinas vista por alguns viajantes estrangeiros no século XIX; SAES, F. 1986. A Grande empresa de serviços públicos na economia cafeeira.
} 
bibliotecas públicas, hotéis, restaurantes, centenas de estabelecimentos comerciais davam a cidade um grande destaque no Oeste Paulista. Cabe assinalar que a crescente presença de imigrantes estrangeiros era representada socialmente através de inúmeras associações, hospitais, escolas e sociedades esportivas e culturais (IBGE, 1952).

Os capitais que proporcionaram as feições urbanas citadas acima também foram alocados em outros setores da economia local. Em algumas áreas os investimentos causaram notável impacto, como, por exemplo, com a fundação da Companhia Paulista de Estradas de Ferro, em 1868. Também nesse ano instala-se na cidade a Companhia Lidgerwood, especializada na montagem de máquinas para o beneficiamento do café. (GEBARA, 1987). Ambas as companhias além de aumentarem os capitais acumulados na região por sua atividade fim, também incrementaram a atividade agrícola, pois permitiam um aumento substancial da produtividade, uma drástica redução de custos, além de poupar a mão de obra empregada no transporte e beneficiamento da produção.

Em 1872, foi fundada na cidade a Companhia Mogiana de Estradas de Ferro e Navegação, junto à instalação dessa companhia surgem oficinas voltadas à construção e manutenção de carros, vagões e locomotivas. Essas oficinas contratam centenas de trabalhadores, e se destacam nacionalmente pela qualidade de seus serviços. Outra companhia importante nesse período é a fundição McHardy, que se integrou a cadeia produtiva gerada pelas ferrovias fornecendo seus serviços as oficinas instaladas e propiciando no final do século XIX cerca de trezentos postos de trabalho aos operários da cidade (IBGE, 1952).

Uma das consequências do destaque alcançado pela cidade devido à riqueza acumulada na produção cafeeira e à crescente urbanização pode ser vista quando foi instalada nessa região a sede do atual Instituto Agronômico de Campinas (IAC). Essa instituição de pesquisa, fundada em 1887 com o nome de Imperial Estação Agronômica de Campinas, surgiu como resultante do crescimento do capital investido na cidade, essa é a conclusão da historiografia ${ }^{20}$ que se voltou a analisar a atuação dessa instituição.

\footnotetext{
${ }^{20}$ Algumas das principais obras que procuraram analisar a criação e atuação do IAC são: DANTES, M. A. M.1979. Institutos de Pesquisa Científica no Brasil; IAC. 1987. Instituto Agronômico de Campinas: 1887-1897: Tem História Pra Contar; MELONI, R. A. 1999 Ciência e Produção Agrícola. A Imperial Estação Agronômica de Campinas 1887/1897.
} 
No arcabouço do projeto de fundação da então Imperial Estação Agronômica de Campinas estava a noção do efeito multiplicador da ciência como potencializador do crescimento econômico local (MELONI, R. A. 1999). Tal afirmação pode ser verificada na própria organização das atividades da instituição e no conteúdo das pesquisas realizadas nesse local.

Para organizar a estrutura de pesquisa a ser alocada na cidade e os trabalhos dos pesquisadores contratados, o governo imperial chamou o químico austríaco Franz Josef Wilhelm Dafert para ocupar o cargo de diretor da Imperial Estação Agronômica. Apesar do propósito inicial da instituição desenvolver atividades de ensino e pesquisa, Franz J. W. Dafert concentrou seus esforços principalmente no estabelecimento das atividades de pesquisa, procurando centrar os estudos no entendimento dos fatores que permitissem a manutenção e a fertilidade das terras da região. Para isso foram realizadas pesquisas básicas sobre a química dos solos, sobre as normas de adubação e sobre os principais problemas que acometiam as culturas da região.

Outros diretores do instituto mantiveram a proximidade com as necessidades locais, incentivando a pesquisa sobre o cultivo do algodão, buscando técnicas de melhoria da fibra e sementes dessa cultura que foi explorada em momentos onde a diversificação da produção agrícola local fez-se necessária. Além do algodão e do milho, o café foi prioritariamente pesquisado no intuito de incrementar a produção e a qualidade do cultivo local (MELONI, 1999).

O caso do IAC é paradigmático, uma vez que nos permite entender como a pesquisa científica estruturada através da ação do Estado vai se relacionar com as demandas da região. É interessante observar que desde os primórdios do surgimento de uma estrutura de C\&T na cidade, a correlação entre a pesquisa científica e os objetivos econômicos locais não é fortuita, a essa característica nos reportaremos adiante, pois acreditamos que ela estará presente de maneira determinante na formação de outra etapa econômica da cidade.

Alguns autores enxergam nessa conjuntura de crescimento urbano e ganhos excepcionais na produção agrícola, conforme descrito nas páginas anteriores, o surgimento das estruturas iniciais que posteriormente serviriam de base para a formação 
do setor industrial em terras paulistas. A disponibilidade de grandes somas de capitais para o investimento inicial seria proporcionado pela expansão cafeeira, pelo impacto ferroviário e a crescente utilização do trabalho livre e suas implicações na constituição de uma economia de mercado interno (CANO, 1977).

Tal análise parece-nos a mais acertada para explicar a relação entre as diferentes formas de acumulação capitalista que florescem em São Paulo, e particularmente na região de Campinas, nas décadas finais do século XX.

Entretanto não podemos dizer que a mentalidade capitalista superou a herança escravista, autoritária e tradicionalista que campeava na época. Alguns apontamentos sobre a atuação da elite campineira nos anos finais do Império apontam como forte evidência das contradições locais o contraste existente entre a adesão a causa republicana e a presença de um enorme contingente de escravos que mourejavam nas fazendas e cafezais da zona rural da cidade. Tais discrepâncias revelam um substrato cultural no qual encontramos incorporadas as noções de direito a propriedade e livre iniciativa, propagada pelo liberalismo, escamoteando desse discurso ideológico os conteúdos relativos à liberdade e a autodeterminação dos povos (CAMPINAS, 1992).

No final do século XIX, a produtividade dos cafezais em Campinas é superada pela frente agrícola que avançava em direção ao Oeste. A fronteira da expansão cafeeira avançava em direção a Ribeirão Preto, Jaú, Brotas e Botucatu. Como consequência desse processo, os Barões do Café campineiros adquirem terras nas novas frentes pioneiras e continuam o movimento de diversificar o investimento de seus capitais (MONBEIG, 1984).

O principal motivo da perda de produtividade das terras de Campinas deve-se ao envelhecimento dos cafeeiros plantados entre as décadas de 1850 a 1870 . Mesmo com o plantio de novas mudas no início do século XX, que substituíram a cultura mais antiga com menor rendimento, a produção se estabilizou, apresentando tendência de declínio nas três primeiras décadas do novo século (SEMEGHINI, 1991).

Um ponto a ser ressaltado está no fato de que mesmo com a estabilização da produção agrícola as funções urbanas da cidade continuaram crescendo e atraindo 
considerável número de imigrantes. Tais imigrantes estabelecem-se na cidade induzidos principalmente pelas possibilidades que a vida urbana permitia. O crescimento urbano é tão significativo que em 1890 Campinas e São Paulo possuíam uma estrutura urbana e populacional semelhante. Entretanto tal disposição não se perpetuou, pois uma epidemia de febre amarela assolou a cidade de 1889 a 1897. Tal epidemia causou um grande impacto demográfico, quase metade da população abandonou a cidade nesses anos. Junto ao esvaziamento populacional, estabelecimentos comerciais e companhias industriais transferiram-se para São Paulo (BERGÓ, 1952).

Medidas sanitárias realizadas pela Companhia Campineira de Águas e Esgoto lentamente controlam o agente transmissor, colocando fim aos charcos e pântanos propícios a presença da doença, reurbanizando as áreas ocupadas desenfreadamente devido ao rápido crescimento populacional anterior, canalizando a água e o esgoto da cidade, permitindo dessa maneira o surgimento de uma infraestrutura que possibilitaria uma nova fase de crescimento. Todavia, a partir do surto de febre amarela, Campinas não mais teria condições de acompanhar o dinamismo comercial e industrial da capital paulista, que no início do século XX despontará sem a concorrência direta de qualquer outra cidade do Estado (BADARÓ, 1996).

Ao final da epidemia, Campinas recuperou seus efetivos populacionais e econômicos, entretanto a capacidade de crescimento vista no século XIX não foi restaurada, e o compasso de desenvolvimento da cidade assumiu um ritmo mais cadenciado.

Enquanto a produção cafeeira entrava em declínio nas décadas iniciais do século $\mathrm{XX}$, a estrutura industrial de Campinas se recuperava das perdas vividas entre 1889 a 1897. Inclusive o setor industrial passou por um processo de diversificação de produção interessante.

Como resultado dessas transformações, as estatísticas mostram que no final da década de 1920 a cidade possuía aproximadamente 93 estabelecimentos industriais, que empregavam 2865 operários (SEMEGHINI, 1991). Destacam-se nessas unidades fabris a produção têxtil e as indústrias voltadas à transformação e beneficiamento das culturas agrícolas locais. As grandes companhias do setor metal/mecânico que possuíam grande 
destaque na segunda metade do século XIX, como a Companhia MacHardy e a Companhia Lidgerwood, entraram em declínio, com grande parte de sua produção transferida para a cidade de São Paulo.

Além dessas indústrias mais significativas, a cidade contava com uma crescente oferta de indústrias no setor de bens de consumo (produtos alimentares, madeira, sabão, metalurgia, etc.).

Podemos sintetizar esse processo afirmando que na primeira metade do século $\mathrm{XX}$, a industrialização em Campinas, mesmo em compasso cadenciado, assumiu feições cada vez mais complexas, conferindo a cidade destaque indiscutível no conjunto dos municípios do interior de São Paulo. Podemos confirmar essa interpretação no trecho a seguir:

\footnotetext{
Por último, na década de vinte, acompanhando a expansão cafeeira e a expressiva industrialização do estado, o parque manufatureiro local cresce e diferencia-se, instalando-se alguns grandes estabelecimentos e diversos setores novos começando a operar. Daí para frente, o próximo grande impulso aconteceria a partir dos anos cinquenta. Mas, no intervalo, esse núcleo continuaria se ampliando, e a cidade continuaria sendo um dos maiores polos fabris do estado (SEMEGHINI, 1991, p.79).
}

Assim, nas décadas de 1930 a 1950, a cidade afastou-se cada vez mais de suas origens agrárias, assumindo feições tipicamente urbanas e industriais. O grande atrativo regional passou a ser a potencialidade de desenvolvimento local como polo alternativo à industrialização paulistana. A prefeitura incentivava o setor industrial oferecendo isenções de impostos, facilitando a aquisição de terrenos e oferecendo infraestrutura atraente devido à disponibilidade de água, energia elétrica e transportes.

Em 1950 a população urbana alcançava a expressiva marca de 100.000 habitantes. Durante o período de crescimento, a Seção de Arquitetura e Urbanismo da prefeitura através de uma Comissão criada por decreto-lei em 1935 planejou e lentamente deu início ao processo de modernização e racionalização das estruturas urbanas da cidade. 
Nesse processo as avenidas antigas foram alargadas e reurbanizadas. O zoneamento foi planejado de maneira a distribuir geograficamente as funções urbanas conforme as necessidades locais, surgindo assim espaços voltados ao comércio e serviços, preferencialmente localizados no centro da cidade. Bairros industriais com moradias operárias foram instalados nas zonas periféricas. Essas zonas produtivas foram instaladas preferencialmente próximas a malha ferroviária para otimizar a distribuição e transporte de mercadorias. Nesse Plano de Melhoramentos Urbanos também se planejava a criação de uma universidade secundária voltada ao ensino normal, comercial e técnico. Pretendia-se atender as demandas locais e superar a dependência das instituições de ensino instaladas na capital (BADARÓ, 1996).

Junto ao movimento modernizador, que através da urbanização pretendia inserir a cidade em uma nova etapa econômica ligada aos ganhos industriais, existia um claro processo de hierarquização, controle e segregação dos grupos sociais não alinhados aos objetivos da elite local. Essas questões foram exaustivamente exploradas em uma dissertação sobre as associações operárias e recreativas surgidas em Campinas na primeira etapa do século XX (NOMELINI, 2007). Um dos resultados dessa análise, que se voltou para o ambiente cultural da cidade nesse momento, está na demonstração de como o caráter conservador e elitista da sociedade local mantinha suas características verificadas no séc.XIX, e como tais fatores influenciaram os rumos tomados pela cidade.

Dessa maneira, a cidade de Campinas nas primeiras décadas do século $\mathrm{XX}$ vivia a grande contradição entre os impulsos modernizadores do industrialismo, e o peso da tradição conservadora legada do passado escravista e oligárquico.

Tal estrutura repressora foi vivenciada por um dos grandes cientistas atuantes no Brasil nesse período, o Padre Roberto Landell de Moura, que teve uma breve passagem na cidade e não recebeu boa acolhida por parte dos seus moradores.

Dotado de uma capacidade intelectual ímpar, Landell de Moura tinha múltiplos interesses, realizando estudos em campos aparentemente distantes, como a Teologia, Medicina, Física Quântica, Química e Psicologia. Entretanto se destacou como pioneiro nas pesquisas sobre telegrafia, radiofonia e telefonia sem fio (FORNARI, 1960). 
No momento do surgimento das pesquisas e registro de patentes que posteriormente formariam o campo da telecomunicações, Landell de Moura desenvolvia soluções tecnológicas equiparáveis as pesquisas dos grandes nomes desse campo, como Marconi, H.Hertz, Popov, e outros ${ }^{21}$. A diferença é que produzia com pouquíssimos recursos, muitas vezes enfrentando franca oposição, devido sua filosofia que admitia uma relação de coexistência entre as verdades do universo físico, demonstradas pelo método científico, e as crenças religiosas do campo da Teologia (QUEIROZ, 2007).

Quando Landell de Moura chegou a Campinas, a reputação de louco, bruxo, padre renegado, médium que ouvia vozes, o precedeu, e o modesto laboratório que conseguiu montar em sua casa foi destruído por fiéis desconfiados. Tal suspeição é justificada devido ao inevitável choque entre a natureza conservadora da cidade e as próprias características revolucionárias da tecnologia eletrônica pouco compreendida pela população local.

Landell de Moura, na realidade, pouco antes tinha realizado com sucesso experiências de emissão e recepção sem fio em uma distância de aproximadamente oito quilômetros, o espaço que separa a Avenida Paulista do Alto de Santana, em São Paulo (FORNARI, 1960). Posteriormente conseguiu registrar patentes dessa técnica. No Brasil a patente foi registrada em 1900, e pouco depois registrou três patentes nos Estados Unidos entre 1901 e 1904. A falta de apoio impediu o desenvolvimento dessa tecnologia em terras brasileiras. Vencido o prazo de 17 anos em que se prescreve a posse da patente, o setor produtivo dos Estados Unidos aproveitou o conhecimento desenvolvido por Landell de Moura (ALMEIDA, 1983).

A passagem de um grande nome da história das telecomunicações, como Landell de Moura, na cidade de Campinas no raiar do século XX poderia ser entendida como o prenúncio da futura vocação local para a pesquisa em tecnologia, particularmente em telecomunicações. Entretanto fazer tal extrapolação é ignorar o caráter essencialmente tradicional da economia e sociedade local no início do século.

\footnotetext{
${ }^{21}$ A inventividade e vanguardismo das pesquisas realizadas por Roberto Landell de Moura são citadas em diversas obras, podemos apontar entre elas: ALMEIDA, B. H. 1983. Outro Lado [da História] das Telecomunicações: A Saga do Padre Landell; FORNARI, E. 1960. O Incrível Padre Landell de Moura; QUEIROZ, F. A. 2007. A Revolução Microeletrônica: Pioneirismos Brasileiros e Utopias Tecnotrônicas.
} 
O mundo ao qual Padre Landell de Moura foi apresentado em sua curta estadia é substancialmente diferente da estrutura econômica e social que emerge na segunda metade do século XX, e que permite a instalação de uma pujante infraestrutura em P\&D e C\&T na cidade de Campinas. Curioso observar que um dos mais importantes institutos de pesquisa instalado na cidade homenageia postumamente a presença do ilustre visitante. O Centro de Desenvolvimento e Pesquisas da Telebrás (CPqD) foi merecidamente batizado com o nome do pioneiro pesquisador em telecomunicações, Roberto Landell de Moura.

Ao final da Segunda Guerra Mundial esboça-se uma nova fase nas relações produtivas das indústrias na região de Campinas com a instalação da grande empresa nacional ou estrangeira. Indústrias como a Rhodia, Votorantin, Pirelli, Singer, Bosch, G.E, 3M, IBM, Sharp, Eletrometal, e outras, concentram-se na cidade e adjacências entre os anos de 1945 a 1960. Assistimos um processo de diversificação e complexificação do parque produtivo local. A partir de então é possível observar a atuação das grandes empresas mecânicas, químicas e eletrônicas que caracterizariam as atividades produtivas da cidade na segunda metade do século XX.

Depois da capital, Campinas tornava-se o principal polo fabril do estado, sendo a atividade industrial a mais importante atuação econômica do município já no início da década de 1950. A crescente participação de grandes companhias industriais pode ser explicada como resultado do processo de internacionalização das grandes corporações estrangeiras, ao mesmo tempo em que o esforço do Plano de Metas, planejado pelo governo Juscelino Kubitschek (1956-1961), atraia o grande capital internacional com o incentivo a indústria de base e os investimentos na infraestrutura de transportes e energia (SEMEGHINI, 1991).

A análise dessa nova fase produtiva identifica uma descontinuidade em termos produtivos, técnicos e financeiros, se considerarmos as etapas econômicas pregressas. A produção industrial a partir de então se caracterizou pela concentração dos fatores produtivos, pela especialização da mão de obra e do território. Tal transformação é resultado das mudanças observadas na grande empresa capitalista, que passou a privilegiar territórios com infraestrutura, rede viária adequada, complexo urbano de 
serviços desenvolvidos e trabalhadores qualificados (CARDOSO DE MELO, 1975). Justamente tais condições foram historicamente construídas na região de Campinas, de maneira que o acelerado desenvolvimento industrial pode ser explicado a partir dessa herança histórica.

Campinas ingressou nessa etapa econômica com todas as condições para realizar com sucesso os objetivos dos novos padrões de acumulação da grande empresa capitalista.

Os equipamentos urbanos forneciam o conforto e a comodidade necessária aos trabalhadores especializados deslocados à região, ao mesmo tempo em que a cultura industrial pregressa permitia o pleno funcionamento da fábrica e da sua estrutura produtiva. As tensões sociais tinham se diluído graças à décadas de esforços dos setores conservadores da cidade, seja através da instalação de projetos de aparência modernizadora, conforme planejado pela Comissão de Notáveis responsáveis pela urbanização (BADARÓ, 1996), seja através da tenaz vigiância aos costumes e moral realizada por uma elite e classe média marcadamente tradicionalista e que dispunham do apoio das forças de segurança, que muitas vezes agiam na repressão contra indivíduos que atuavam fora da homogeneidade cultural almejada pelos expoentes locais (NOMELINI, 2007).

Além das comodidades, Campinas contava com uma excelente malha de transportes. Era servida desde o período imperial por um eficiente sistema ferroviário. Nos anos 60 já estava ligada a uma das então consideradas melhores estradas pavimentadas e duplicadas do país, a Rodovia Anhanguera, que passou a unir a cidade a São Paulo. Também nessa década foi instalado um aeroporto internacional localizado no bairro de Viracopos.

As crescentes necessidades técnicas e cientificas que surgiam seriam supridas graças aos investimentos do governo estadual e federal. Tais investimentos são justificados tendo em vista o expressivo crescimento econômico local, e a partir deles foi possível à instalação de uma considerável estrutura de $\mathrm{P} \& \mathrm{D}$ e C\&T na região. Dessa estrutura científica e tecnológica emergiu como conceito realizável nas condições locais a formação do polo tecnológico de Campinas. 
Analisaremos a seguir como os polos tecnológicos aparecem como unidade econômica na estrutura industrial capitalista e como esse conceito pode ser implementado em terras campineiras.

\subsection{Ciência e Economia na Construção do Eldorado Tecnológico: O Caso do}

\section{Vale do Silício}

Na primeira metade da década de 1990, Manuel Castells e Peter Hall realizaram uma abrangente análise sobre os polos tecnológicos, que naquela época estavam em franco processo de crescimento. A partir da análise comparativa entre os diferentes centros produtivos de alta tecnologia estudados, e dos processos que nortearam essas iniciativas, os autores propuseram uma descrição geral que buscava definir o que seria um polo tecnológico e quais seriam seus objetivos. É essa definição que vai nortear nosso entendimento sobre essa unidade técnico-produtiva:

Generally, tecnopoles are planned developments. Some are pure private sector real-estate investments, and these happen to be among the most numerous but least interesting. A significant number, however, have resulted from various kinds of cooperation or partnership between the public and private sectors. They are promoted by central or regional or local governments, often in association with universities, together with the private companies that occupy the resulting spaces. And these technopoles, the more interesting ones, are invariably more than just plots to rent. They also contain significant institutions of a quasi-public or nonprofit type, such as universities or research institutes, which are specifically implanted there in order to help in the generation of new information. For this is the function of the technopole: it is to generate the basic materials of the informational economy (CASTELLS, M.; HALL, P. 1994, p.1).

A descrição citada acima nos interessa na medida em que nos permite perceber as múltiplas configurações assumidas pelos polos tecnológicos, sua relação com as universidades e institutos de pesquisa e a tendência de assumirem um papel cooperativo entre as demandas do setor privado e público.

É preciso ter em mente que cada polo tecnológico tem sua organização estrutural e limites específicos definidos pelo desenvolvimento histórico da região no qual está 
inserido e de dinâmicas amplas de caráter global. Ou seja, é preciso ter clara a noção de que essas unidades são construídas histórica e socialmente. Não podemos avaliar o surgimento e desenvolvimento dos polos tecnológicos como estruturas independentes das relações históricas e sociais determinadas no tempo e no espaço.

Nesse sentido, vamos analisar brevemente as origens históricas desse processo. Para isso consideraremos principalmente os fatores que permitiram o surgimento do primeiro polo tecnológico, que geograficamente teve lugar na região de Santa Clara, Califórnia, e suas adjacências ${ }^{22}$. Essa área posteriormente passou a ser conhecida como Vale do Silício.

O fator mais surpreendente, e que talvez explique a grande empolgação em torno dos polos tecnológicos, é que em sua origem a região de Santa Clara tinha por base econômica, até o ano de 1950, a agricultura. As estatísticas históricas da região apontam que no início dessa década trabalhavam em manufaturas no condado de Santa Clara apenas 800 operários, esses operários em sua grande maioria prestavam serviços às indústrias de beneficiamento da produção alimentar local (BERNSTEIN,1977). Se lembrarmos das condições da indústria instalada na região de Campinas, por exemplo, veremos que na metade da década de XX existia nessa cidade do interior de São Paulo uma estrutura econômica muito mais desenvolvida do que a do Vale do Silício. Esse fator não pode ser subestimado quando pretendemos entender os motivos que levaram países estrangeiros a buscar replicar esse processo em suas economias.

Entretanto, devemos salientar que em Santa Clara existia uma tradição de P\&D na área de eletrônica e telecomunicações que pode ser rastreada desde o ano de 1912. Nessa data, a Federal Telegraph Company, com a liderança do físico Lee De Forest, e apoio da Universidade Stanford, começou a desenvolver pesquisas sobre o uso do tubo de vácuo nas transmissões telegráficas. A presença de pesquisadores vinculados a Universidade de Stanford no setor produtivo será uma constante a partir de então, como, por exemplo, através da atuação do Dr. Harris Ryan, responsável pela formação de

\footnotetext{
${ }^{22}$ Estudos aprofundados sobre o desenvolvimento urbano e industrial do Vale do Silício podem ser vistos em: SAXENIAN, A. L. 1981. Silicon Chips and Spacial Structure: The Industrial Basis of Urbanization in Santa Clara Valley. Idem, 1989. The Political Economy of Industrial Adaptation in Silicon Valley.
} 
inúmeros engenheiros eletrônicos que passaram a desenvolver projetos em engenharia eletrônica na região de Santa Clara (CASTELLS; HALL, 1994).

Todavia, a ligação mais duradoura e propositadamente direcionada entre a pesquisa desenvolvida na universidade e o incipiente setor produtivo em eletrônica que surgia em Santa Clara foi patrocinada pelo professor Frederick Terman.

Terman se doutorou em engenharia elétrica no Instituto de Tecnologia de Massachusetts (MIT), posteriormente assumiu o cargo de professor de Engenharia de Rádio em Stanford, posição que o permitiu chegar a Diretoria do Laboratório de Comunicações e posteriormente Decano do Departamento de Engenharia Elétrica. Na década de 1950, se tornou Reitor da Universidade de Stanford.

Diversas empresas de eletrônica que se instalaram na região de Santa Clara receberam o apoio decisivo de Frederick Terman. Inclusive, em alguns casos, Terman chegou a investir na criação de companhias projetadas por seus alunos, como em 1938 quando emprestou a soma de U\$1.538,00 a William Hewlett e David Packard. Muitas dessas companhias conseguiram grande prosperidade durante a Segunda Guerra Mundial, momento onde as forças armadas patrocinaram o desenvolvimento desse setor devido à procura por equipamentos eletrônicos. Os investimentos militares foram alocados em algumas companhias da região de Santa Clara. Com isso, a empresa formada com modestos capitais por William Hewlett e David Packard no ano de 1942 conseguiu vender U\$1 bilhão de dólares em equipamentos, a maior parte desses valores foi obtida através de contratos com os militares (ROGERS; LARSEN, 1984).

Após a Segunda Guerra Mundial, Terman pode dar continuidade ao seu plano de aproximar a pesquisa acadêmica das necessidades do setor produtivo. Uma das alternativas encontradas que permitiram o aceleramento dessa integração foi com a criação do Stanford Industrial Park, em 1951. Terman aproveitou a disponibilidade de terras em posse da Universidade de Stanford e criou um processo de arrendamento de lotes a alunos e professores dispostos a desenvolver empresas de tecnologia nas imediações da universidade. 
O propósito por trás dessa iniciativa era de aproveitar da melhor maneira possível o conhecimento produzido nos laboratórios de pesquisa acadêmica pelas empresas que surgiriam no entorno do campus universitário.

Tal projeto foi muito bem sucedido, em 1960, já estavam instaladas 32 empresas no Stanford Industrial Park. Dez anos mais tarde, o sucesso era absoluto, mais de 70 empresas voltadas à alta tecnologia se estabeleciam na região do Vale de Santa Clara, que por atrair as maiores empresas de eletrônica do país, a partir de então passou a ser conhecida como Vale do Silício (SAXENIAN, 1990).

Outro nome importante para entendermos o caráter inovador das tecnologias desenvolvidas no Vale do Silício é o de William Shockley. Famoso por seu ativismo e análises pseudocientíficas a favor do racismo nos anos 70, esse físico conseguiu dar uma enorme contribuição para as pesquisas em eletrônica realizada no Vale do Silício. Tal contribuição foi possível graças a sua experiência acumulada como cientista do Bell Laboratories, em Nova Jersey. Em 1947, Shockley fez parte do time laureado com o Nobel de Física pelo desenvolvimento do transistor. Poucos anos mais tarde procurou abrir sua própria empresa no ramo da eletrônica e seu projeto recebeu acolhida em Montain View, próximo ao Vale do Silício (MUTLU, 1979).

Fundada em 1955, a Shockley Semiconductors Laboratory contratou diversos engenheiros recém-formados em Stanford, nessa empresa reúnem-se jovens de uma geração que ficaria posteriormente marcada por desenvolver e comercializar o circuito integrado, inovação que faria muitos desses engenheiros milionários, com participação no surgimento de diversas empresas, como a Intel, a National Semiconductors, a Amelco and Advanced Micro Devices, e outras (SAXENIAN, 1990).

Entre a década de 50 e meados dos anos 70, mais de quarenta companhias de semicondutores se aglomeraram na região do Vale do Silício formando a maior região de indústrias especializadas nessa tecnologia no mundo. Empresas que não eram originárias dessa área instalaram unidades nesse polo tecnológico.

Tal atratividade e sucesso são explicados graças à sinergia formada entre os laboratórios de pesquisa de Standford e as constantes trocas de informação entre as 
empresas instaladas ao redor da universidade. Passou a fazer parte da cultura local a busca empreendedora pela inovação. Nesse ambiente, engenheiros, cientistas e técnicos circulavam pelas diferentes companhias em busca de melhores oportunidades, levando consigo novos conhecimentos, sendo que muitas vezes sentiam-se confiantes a desenvolver seus próprios empreendimentos (CASTELLS; HALL, 1994). A disponibilidade de conhecimento técnico, o ambiente social favorável ao empreendedorismo e inovação tecnológica, a presença de um corpo profissional altamente qualificado que circulava pelas diferentes empresas, esses são alguns dos fatores por trás das grandes companhias de semicondutores que se desenvolveram no Vale do Silício.

Na década de 1970, outra geração de jovens proporcionaria uma nova fase de expansão econômica ao Vale do Silício. Trata-se dos engenheiros eletrônicos e programadores responsáveis pelo desenvolvimento dos computadores pessoais.

O primeiro computador pessoal, nomeado como "Altair", foi desenvolvido pelo engenheiro Henry Edward Roberts, em 1974. Com o surgimento desse equipamento, que se destacava pelo preço relativamente acessível, rapidamente grupos de discussão sobre eletrônica, assim como revistas especializadas, divulgam a novidade e jovens programadores começaram a desenvolver softwares que conquistam a atenção de um crescente público graças às possibilidades de análise e processamento de informação (FREIBERGER; SWAINE, 1984).

$\mathrm{Na}$ região do Vale do Silício, alguns engenheiros e investidores cientes das potencialidades econômicas dessa inovação criam pequenas empresas que rapidamente conseguem fatias cada vez mais expressivas do mercado recém-criado para computadores pessoais; de pequenas empresas locais essas companhias se tornam gigantes multinacionais em questão de anos. Nesse processo é que as surgem algumas das grandes corporações que hoje são extremamente conhecidas, como a Microsoft (1975) e a Apple (1976). Logo no início da década de 1980, a gigante IBM entrou no mercado de desenvolvimento de equipamentos para computadores pessoais, confirmando as potencialidades e lucros desse novo setor da economia. A partir de então, o crescimento de indústrias associadas ao desenvolvimento em Hardware e 
Software para computadores pessoais passou a mobilizar setores inteiros da economia, e o Vale do Silício manteve sua proeminência como centro de inovações da indústria da informação (CASTELLS; HALL, 1994).

Como vimos, se recuperarmos os principais fatores que permitiram o rápido desenvolvimento da indústria eletrônica no Vale do Silício podemos ter uma primeira impressão de que todo o processo se resume na materialização das potencialidades da livre iniciativa. Dentro dessa perspectiva, poderíamos dizer que os agentes econômicos dotados de uma visão empreendedora e possuidores de uma exclusiva cultura para inovação tecnológica construíram um sistema produtivo dinâmico e altamente lucrativo.

Em parte essa explicação é verdadeira. Realmente no Vale do Silício a dinâmica empreendedora e o papel da inovação tecnológica respondem por parte considerável do sucesso econômico local (SAXENIAN, 1990). Entretanto, o crescimento extremamente rápido e os excepcionais ganhos auferidos pelas companhias eletrônicas dessa região só podem ser explicados através da ativa participação de um poderoso financiador externo, nesse caso estamos falando da atuação do Estado (CASTELLS, 1999).

No final da década de 1950, o acirramento das tensões entre os Estados Unidos e a União Soviética levou as forças armadas norte-americanas a um processo de modernização e maciço investimento em armamentos e equipamentos militares. Nesse momento, o Departamento de Defesa dos Estados Unidos passou a ser um dos maiores investidores no desenvolvimento da eletrônica do país. Para se ter uma ideia da importância dos investimentos militares, $70 \%$ das encomendas recebidas pelas empresas de semicondutores atuantes no final dos anos 50 tinham origem em licitações das forças armadas. A partir de 1960, os valores ficam próximos a 50\%; quantidade menor, mas ainda extremamente significativa (SAXENIAN, 1990).

Outro importante financiador da indústria eletrônica foi $\mathrm{o}$ programa aeroespacial. Quando a União Soviética coloca o primeiro satélite de telecomunicações em órbita, o Sputnik, o governo norte-americano se envolveu intensivamente na corrida tecnológica contra os países comunistas, esse processo passou a ser conhecido como "Corrida Espacial", e teve como resultado o crescente fomento a toda cadeia produtiva voltada para a eletrônica nos Estados Unidos (MARKUSEN et al, 1991). 
No vale do Silício, a Fairchild Semiconductor, uma companhia formada por alguns dos jovens engenheiros que deixaram a Shockley Semiconductors Laboratory devido a divergências pessoais e criativas com o controverso físico William Shockley, recebeu, em 1959, U\$1,5 milhões em um contrato para fornecer desenvolver os transistores que seriam utilizados no míssil balístico intercontinental Minuteman. Posteriormente desenvolveram os circuitos integrados utilizados pelos computadores das missões Apollo. Contratos desse porte passaram a ser assinados por diversas empresas, permitindo um grande volume de capital necessário a P\&D das incipientes tecnologias que então seriam comercializadas. Esses investimentos milionários respondem por parte considerável do sucesso da indústria de semicondutores na região do Vale do Silício (MARKUSEN et al, 1991).

Conforme pudemos ver, na formação do primeiro polo tecnológico do mundo diversos fatores foram mobilizados para a construção de uma estrutura produtiva baseada na alta tecnologia.

Porém, alguns desses fatores decisivos são de caráter extremamente singular. $\mathrm{Ou}$ seja, não podem ser replicados em outros espaços devido aos condicionantes históricos particulares da região, do grupo de cientistas e empreendedores e do perfil das demandas promovidas pelo Estado em um contexto extremamente singular.

Vamos citar alguns desses fatores apenas a título de ilustração - a iniciativa do magnata Leland Stanford, em 1882, ao fundar uma universidade em Palo Alto, Califórnia. A localização geográfica da universidade em uma região essencialmente rural permitiria dois aspectos fundamentais para o surgimento de um polo tecnológico, tradição em pesquisa científica e disponibilidade de terras que poderiam ser incorporadas aos investimentos industriais a baixo custo. Também podemos citar a existência de elos que relacionam a pesquisa realizada nas universidades, que nem sempre estava interessada às demandas produtivas no começo do século XX, a um setor industrial disposto a explorar tecnologias pioneiras. Essa dimensão foi ocupada pela atuação dos professores Harris Ryan e Frederick Terman, e seus ousados alunos. O posicionamento dos Estados Unidos em alguns dos grandes acontecimentos desse período também teve considerável impacto para o financiamento das indústrias locais. 
Mesmo o ambiente cultural voltado para a inovação científica e pautado pelo empreendedorismo comercial é altamente exclusivo. Analisando detalhadamente, o desenvolvimento histórico que ocorreu no Vale do Silício é altamente marcado pela individualidade.

Apesar dessa excepcionalidade, tal episódio inspirou a criação de inúmeras réplicas. Cidades tecnológicas, parques tecnológicos, polos tecnológicos proliferam-se nas mais diversas regiões do planeta. E em todas essas regiões procura-se em algumas escala replicar o sucesso verificado no Vale do Silício.

Interessante observar como Manuel Castells e Peter Hall colocam essa questão. Para esses pesquisadores, buscar o objetivo de se alcançar o novo arranjo produtivo baseado na alta tecnologia, é colocar uma meta que parece ultrapassar as fronteiras do planejamento econômico, conforme essa análise:

\footnotetext{
It is somewhere in this twilight zone - of facilitating technological innovation and business entrepreneurialism, without suffocating inter-firm competition and human imagination - that the magic lies: the leadership of a new tecnological era. As Spanish explorers sought untold treasure, regions and cities around the world now seek a similiar goal, now redefined: the twenty-first-century Eldorado. Perhaps, like their sixteenth-century equivalents, they Will find that the ultimate goal, the inovative milieu, will never materialize. But perhaps, like them, they will discover a continent in the process. Or, at least a modest piece of estate that will generate new wealth from information (CASTELLS, M.; HALL,P. 1994, p.237)
}

Conforme vimos no trecho, os pesquisadores identificam que as iniciativas que pretenderam replicar a experiência do Vale do Silício são carregadas de traços utópicos. A busca pelo "Eldorado" do século XXI, e o termo Eldorado encaixa-se perfeitamente na ideia que procuram demonstrar, necessita de apostas convictas nas potencialidades da tecnologia, além da busca de um equilibrio alquímico entre a necessidade de competição do capitalismo, com a exigência de cooperação e criatividade para inovação. Imaginar esse ambiente ideal equivale imaginar um futuro nunca realizável, mas muito sedutor por suas possibilidades. Tais fantasias de alta tecnologia foram encenadas reiteradamente nos anos finais do século XX. 
Cabe ao historiador analisar como é possível um fato singular, como o desenvolvimento da indústria de alta tecnologia no Vale do Silício, ser mobilizado socialmente e perseguido como objetivo de diversos planejamentos econômicos realizados por grandes potências, ou por países que naquele momento histórico eram definidos como subdesenvolvidos.

Partimos do entendimento que tais visões projetivas não são exclusivas do século XX. Pelo contrário, as utopias como tradição de pensamento constituem um corpo discursivo extremamente antigo e tiveram grande impacto na mobilização tanto de imaginação criativa, quanto de recursos produtivos: "A utopia está no horizonte de homens e mulheres que estão pensando o trabalho e a sociedade do século XXI, como estava desde a antiguidade e passando pelos modernos" (QUEIROZ, 2007, p.37).

O historiador F. A. de Queiroz ao analisar as utopias como forma de construção cultural, social, religiosa e econômica, recupera em sua investigação o percurso histórico que aponta como os pensadores utópicos mobilizaram diversos substratos culturais ao projetar o futuro. Podemos usar essa análise para verificar as múltiplas facetas assumidas pela utopia - podemos citar as utopias religiosas, que narram o ancestral Éden do qual a humanidade foi expulsa, ou a escatologia milenarista medieval, que planejava um mundo de graças e benções aos fieis, também pode ser elencada as sociedades utópicas imaginadas por Platão (428/427 - 348/347 a.C), Campanella (1568 - 1639), Morus (1478 - 1535), ou as projeções coletivistas planejadas pelo socialismo utópico de Fourier (1768 - 1830), Owen (1771 - 1858) e Simon (1760 - 1825) (QUEIROZ, 2007). São inúmeras as utopias que poderiam ser aqui citadas.

A utopia como projeção de um horizonte histórico desejável, mas nunca plenamente realizável, estimulou a mentalidade e os conhecimentos de cada época para idealizar o futuro. Dentro dessa lógica, a ciência, como regime discursivo privilegiado na época moderna e na contemporaneidade, logo foi inserida em inúmeras projeções utópicas. Surgem obras onde conteúdos aparentemente equidistantes se sobrepõem, narrativas onde o cálculo e a imaginação, a lógica e o sonho, a razão e a fantasia se complementam para idealizar o futuro: 
Assim, desde as grandes navegações dos séculos XV e XVI, com um alargamento sem precedentes dos horizontes da terra e do imaginário humano, a ciência e a utopia nascem e se desenvolvem como formas de pensar e se dar conta das novas realidades descobertas. Há uma certa tendência a se concebê-las como coisas antagônicas ou contraditórias, como se uma fosse atributo maior e quase exclusivo da "razão" (a ciência) e a outra, da fantasia e "imaginação" (a utopia). O que ocorre é que essa oposição ou negação não existe (QUEIROZ, 2007, p.41-42).

Por seu conteúdo potencialmente transformador, a ciência forneceu subsídios para inúmeras obras de antecipação tecnológica e projeções futurísticas. Visões que por vezes ganham feições otimistas, eutopias nas quais a ciência move o mundo para futuros de positividade ilimitada, por exemplo, conforme a imaginação do empresário Walt Disney (1901 - 1966) esboçada em um brinquedo de seu parque de diversões (Tomorrowland), ou as entrevistas e artigos assinados pelo cientista e inventor Nikola Tesla $^{23}$ (1856 - 1943), textos nos quais imaginava um futuro onde as demandas do meio ambiente, do desenvolvimento econômico e do controle de doenças e crimes seriam superadas graças a sua aposta na tecnologia e em suas controversas defesas a eugenia (TESLA, 1937).

Ademais, a ciência forneceu argumentos para romances e contos que desvelam o futuro e suas potencialidades, um dos percussores dessas narrativas, que mais tarde seriam chamadas de ficção científica, foi Jules Verne (1828 - 1905), que idealizou obras onde personagens visitavam ambientes singulares, como abismos oceânicos ou a Lua, utilizando máquinas poderosas dotadas de forças até então pouco conhecidas como a eletricidade. Além disso, também na literatura surgem textos que retratam o lado negativo da utopia tecnológica, podemos citar George Orwell (1903 - 1950) e Aldous

\footnotetext{
${ }^{23}$ Nos últimos anos assistimos a um renovado interesse sobre a obra e o trabalho de Nikola Tesla no Vale do Silício. Neste local, o inventor foi homenageado com uma estátua no ano de 2013. Também no Vale do Silício está sediada uma montadora de veículos elétricos batizada de Tesla Motors, nome escolhido graças ao pioneirismo das pesquisas em eletricidade e ao entendimento de que o cientista realmente foi um visionário ao enxergar as inúmeras aplicações para essa tecnologia. Elon Musk, dono do conglomerado industrial que abrange entre outras empresas a Tesla Motors, criou um fundo de investimentos que arrecadou algo em torno de U\$2 milhões para construir um museu no antigo laboratório do inventor em Long Island, Nova Iorque. Além disso, filmes e biografias sobre o cientista surgiram nos últimos anos. Esse crescente entusiasmo demonstra o quanto as utopias imaginadas por Tesla ainda são fontes de inspiração para um público cada vez mais identificado com as promessas utópicas da ciência e tecnologia.
} 
Huxley (1894 - 1963) como grandes expoentes da literatura voltada a analisar as distopias tecnológicas ${ }^{24}$.

Ainda em sua análise, Queiroz recorrendo à pesquisa de Kumar identifica:

a utopia científica procura explorar todos os recursos da moderna ciência e tecnologia, não obstante, como já foi dito, o avanço científico nunca seja, em si mesmo, o objetivo da utopia. A ciência foi sempre colocada a serviço de algum ideal ético ou social (QUEIROZ, 2007, p.46).

É exatamente a essa dimensão da utopia que recorremos para entender o súbito e avassalador fenômeno do "Eldorado Tecnológico" identificado por Castells. O Vale do Silício ao surgir como uma poderosa unidade econômica em sintonia com os objetivos e práticas da Revolução Microeletrônica traz em si uma ilimitada potencialidade de inspiração. Os ganhos econômicos expressivos, a nova indústria tecnológica com suas promessas de produção "limpa" e "sustentável", o apelo à modernidade e ao futuro, todos esses são agentes extremamente sedutores que inspiraram réplicas nas mais diversas partes do globo, do Japão a França, da Sibéria a Campinas. A possibilidade de construção do complexo industrial do século XXI incendiou a imaginação de políticos, industriais, cientistas e trabalhadores comuns.

A seguir vamos analisar como as promessas associadas às potencialidades da C\&T se materializaram em terras paulistas, focando essencialmente nas estruturas que permitiram a construção de um polo tecnológico em Campinas e os limites que circunscreveram esse projeto.

\footnotetext{
${ }^{24}$ Pretendemos nessas páginas elencar alguns pensadores/idealizadores que trabalharam com conteúdos voltados à antecipação tecnológica, utopia e futurologia. Não pretendemos com tais citações esboçar uma análise do conteúdo de cada obra ou projeto, ou mesmo esgotar o assunto, pretendemos apenas demonstrar a recorrência histórica de temas ligados à utopia. Citamos como obras de referência que aprofundam a análise sobre esse assunto: COTARELO, R. G 1981. .Las Utopias en el Mundo Occidental; JACOBY, R. 2007. Imagem Imperfeita: Pensamento Utópico Para Uma Época Antiutópica; KUMAR, K. 1997. Utopianism; MANNHEIN, K. 1972. Ideologia e Utopia; MORENTE, J. J. 1984. Lo Utópico y la Utopía; QUEIROZ, F. A. 2007. A Revolução Microeletrônica: Pioneirismos Brasileiros e Utopias Tecnotrônicas; SALIBA, E. T. 1991. As Utopias Românticas; SZACKI, J. 1972. As Utopias.
} 


\subsection{Do Vale do Silício à Campinas: Pesquisa e Desenvolvimento e} Instituições de Ensino Superior a Serviço do Modelo Brasileiro de

\section{Desenvolvimento}

Conforme já vimos, em Campinas, as demandas sociais a favor de uma universidade podem ser resgatadas pelo menos até o ano de 1935. Nesse ano, a Seção de Urbanismo e Arquitetura da prefeitura iniciou o planejamento modernizador das estruturas urbanas da cidade. Dentro desse planejamento estava colocada a demanda por uma universidade voltada ao ensino normal, comercial e técnico (BADARÓ, 1996). Também data desse período o surgimento de reivindicações a favor de uma faculdade voltada ao ensino de medicina. Tal faculdade chegou a ser criada por lei, em 1959, contudo nunca foi instituída conforme planejado (GOMES, 2007).

Em 28 de dezembro de 1962, em um dos últimos atos de seu mandato, o governador Carvalho Pinto criou a Universidade de Campinas, que na prática, até o ano de 1966, era constituída apenas pelo curso de Medicina (GOMES, 2007).

A estruturação da universidade começou a ser efetuada apenas no final do ano de 1965. Nesse ano, o médico Zeferino Vaz foi convidado pelo governador Laudo Natel a assumir os trabalhos de organização da universidade através da Comissão de Organização da Universidade, da qual foi nomeado presidente ${ }^{25}$. Em 1969, Vaz assumiu a reitoria, cargo que manteve até 1978.

Para entendermos a escolha de Zeferino Vaz para essa posição é preciso resgatar a biografia desse acadêmico e administrador universitário. Vaz consolidou uma posição de respeito dentro da academia paulista e conseguiu se cercar de apoiadores influentes durante sua longa trajetória em instituições universitárias. Sua carreira se iniciou no Instituto Biológico (IB), na cidade de São Paulo. Posteriormente ocupou a cadeira de Zoologia Médica e Parasitologia da Faculdade de Medicina Veterinária da Universidade de São Paulo (FMVZ/USP), nessa faculdade chegou a ocupar ocupou o cargo de diretor entre 1936 a 1947. Ao participar do Conselho Universitário por vinte e sete anos, inclusive como diretor, chegou a ter considerável destaque - em depoimento revela ter

\footnotetext{
${ }^{25}$ Entrevista com Zeferino Vaz.
} 
influência a ponto de ser um "fazedor de reitores" ${ }^{26}$ - também atuou na instalação bem sucedida da Faculdade de Medicina na cidade de Ribeirão Preto.

Independentemente do respeito de seus pares na academia, Zeferino Vaz contava com livre trânsito no gabinete de diversos governadores do Estado de São Paulo ${ }^{27}$, como Lucas Nogueira Garcez, que o escolheu para a diretoria da Faculdade de Medicina de Ribeirão Preto, e Laudo Natel, que o chamou para planejar e estruturar a Universidade de Campinas.

Além do bom relacionamento com os dirigentes da política paulista, Zeferino Vaz era visto com simpatia pela cúpula do regime militar. Colaborador desde as vésperas do golpe de 1964 - momento onde atuou garantindo o transporte de tropas através do fornecimento de 250 peruas e depósitos de gasolina - foi convocado pelo presidente Castello Branco a ser interventor federal na Universidade de Brasilia ${ }^{28}$ (UnB), posto que ocupou durante um ano e quatro meses. Nesse episódio se aponta a associação com atividades de repressão a funcionários, professores e alunos dessa instituição (UNIVERSIDADE DE BRASÍLIA, 2015).

Tirante sua orientação ideológica favorável ao ambiente autoritário instalado pelo golpe de 1964, a escolha de Zeferino Vaz também está ligada a sua considerável habilidade de gestor acadêmico e a sua visão arrojada quanto à atuação da universidade no país. O sucesso em Ribeirão Preto, local onde conseguiu atrair cientistas de renome e estruturou um curso de medicina moderno e progressista (RODRIGUES, 2002), abriu as portas para que ele pudesse planejar livremente uma universidade baseada nos ideais de integração do pensamento, racionalização dos espaços e íntima relação com as demandas públicas e privadas (JOIA, 2000). Podemos ver parte desse ideal materializado na própria distribuição territorial das unidades e institutos, conforme planejado no projeto arquitetônico e urbanístico da Unicamp. Ambicioso em suas pretensões, Zeferino Vaz buscava como referência a Ágora da polis grega ${ }^{29}$.

\footnotetext{
${ }^{26}$ Idem.

27 Idem.

${ }^{28}$ Idem.

${ }^{29}$ Idem.
} 
A ousadia de pensamento e habilidade de negociação permitiram que o reitor atraísse intelectuais das mais diversas tendências ideológicas. Em poucos anos, Zeferino Vaz conseguiu formar uma estrutura universitária considerável. Entre esses intelectuais podemos citar desde físicos celebrados na época, como César Lattes, passando por economistas, como Maria da Conceição Tavares e Luiz Gonzaga Belluzo, e diversos outros acadêmicos que despontavam como referência em seus respectivos campos de atuação.

Em um momento de repressão política e ideológica, inclusive com a interferência do SNI (Serviço Nacional de Inteligência) nas universidades, Zeferino Vaz conseguiu abrir espaços de negociação, e em algumas situações, inclusive chegou a barganhar com a linha dura do regime - por exemplo, em troca de imunidade dentro do espaço universitário, Vaz contratou coronéis aposentados do SNI como professores titulares da disciplina Problemas Brasileiros presente em cursos do Instituto de Filosofia e Ciências Humanas (IFCH/Unicamp). Como consequência da boa aceitação que o esse reitor tinha por parte do regime militar, e devido a sua capacidade de manobra e negociação, foi garantido espaços de relativa liberdade intelectual dentro dos muros da UNICAMP $^{30}$ mesmo durante o período de maior repressão ideológica da Ditadura Militar.

As terras escolhidas para receber a estrutura universitária foram recebidas como doação de João Adhemar de Almeida Prado. Essas terras eram parte da fazenda Rio das Pedras, lugar de prestígio no passado histórico campineiro, inclusive por ter recebido em uma oportunidade o então imperador D. Pedro II (GOMES, 2007).

A familia Almeida Prado, doadora das terras nas quais a universidade foi instalada, se notabilizava por sua distinção social e influência na elite paulista. $\mathrm{Na}$ genealogia dessa família encontramos dois capitães-mor e um ouvidor da nobreza imperial. Os Almeida Prado também se distinguiam por sua opulência. Além das terras em Campinas, tinham posses em Sorocaba, Itu, Jaú, etc. Com o crescimento da riqueza proveniente da cafeicultura se tornaram capitães da indústria e banqueiros. Ou seja, essa família representava autenticamente a aristocracia do interior paulista. Elite econômica

\footnotetext{
${ }^{30}$ Entrevista com José Ellis Ripper.
} 
que aproveitou os ganhos da agricultura para diversificar seu patrimônio e manter sua ascendência na alta sociedade.

A doação das terras para a instalação da universidade pela família Almeida Prado conecta o passado aristocrata do interior paulista com a moderna cidade industrial, que na segunda metade do século XX estava pronta para viver mais uma fase de desenvolvimento econômico e social.

Com a disponibilidade de um extenso terreno, iniciada os projetos de construção dos prédios e contratado o primeiro grupo de professores, Zeferino Vaz fez valer seu livre trânsito dentro do regime militar e partiu em busca de financiamento. Ao recorrer ao secretário de planejamento do Estado de São Paulo, Dilson Funaro, conseguiu Cr\$ 5 milhões para equipamentos e edifícios. Também foi colocado em contato com Marcos Viana, do BNDE, e José Pelúcio Ferreira, da Finep. Com a demora do repasse do aporte financeiro, o reitor procurou diretamente o ministro Delfim Netto, com o qual tinha relações desde o período em que esteve no Conselho Universitário da USP. Delfim Netto agilizou o processo de repasses dos recursos e garantiu que as portas da Finep e da Secretaria de Tecnologia Industrial estivessem sempre abertas ${ }^{31}$.

Podemos elencar também as contribuições do CNPQ e da Fapesp nesse processo. Além de disponibilizarem recursos para a construção de laboratórios, essas instituições chegaram, inclusive, a pagar a viagem de volta de diversos professores que até então estavam trabalhando em instituições de ensino e pesquisa no estrangeiro ${ }^{32}$.

Além da boa vontade do Regime em relação a sua pessoa, Zeferino Vaz contou com um ambiente favorável na política de financiamento a $C \& T$ que vigorava naquela conjuntura, pois a partir do governo Costa e Silva (1967 - 1969), o Modelo Brasileiro de Desenvolvimento incorporou o incentivo a $\mathrm{P} \& \mathrm{D}$ e $\mathrm{C} \& \mathrm{~T}$ como fator de estímulo ao crescimento econômico (GUIMARÃES, 1985). Pesquisas que proporcionassem aplicações e inovações tecnológicas passaram a ser largamente subsidiadas, a Unicamp se aproveitou descomedidamente desse ambiente para se estruturar. A partir desse

\footnotetext{
${ }^{31}$ Entrevista com Zeferino Vaz.

${ }^{32}$ Entrevista com Rogério Cezar de Cerqueira Leite.
} 
sistema de apoio e fomento a pesquisa, inclusive, é que surgiu o polo tecnológico de Campinas.

Ainda sobre a contratação de professores, o momento histórico favoreceu a incorporação de pesquisadores e docentes que se encontravam radicados no exterior. $\mathrm{O}$ fim da década de 1960 corresponde ao período onde o governo procurou estancar o que foi nomeado como "fuga de cérebros" pela imprensa da época ${ }^{33}$.

A historiografia que analisou esse período (SKIDMORE, 1988), identifica que ao final dos anos 60 foi criada uma força-tarefa pelo governo federal, esse grupo foi responsável por atrair talentos que pudessem concretizar a aposta do governo em impulsionar as metas desenvolvimentistas com investimentos em C\&T.

O principal objetivo dessa força tarefa formada por diplomatas, políticos e até membros das forças armadas, era o de demonstrar aos cientistas brasileiros que o Brasil pós AI-5 tinha se convertido em um lugar seguro para o pesquisador disposto a colocar o projeto do "Brasil Potência" em curso. Também demonstraram, em inúmeras reuniões e encontros com esses cientistas, que o Estado estava disposto a disponibilizar recursos e investimentos para projetos no âmbito da $\mathrm{P} \& \mathrm{D}$ e C\&T, além de ressaltar os consequentes ganhos pessoais e institucionais presentes nessa oferta (SKIDMORE, 1988).

A intenção do governo, quando promove tal campanha de apoio explícito aos cientistas que se encontravam no exterior, era atrair pesquisadores altamente qualificados que pudessem colocar em marcha uma nova fase do desenvolvimento econômico brasileiro. Nessa nova fase, era impreterível a superação de obstáculos infraestruturais a partir do desenvolvimento da ciência e tecnologia nacionais. Decidido a superar os entraves tecnológicos que dificultavam o projeto desenvolvimentista, o Estado brasileiro passou a investir pesadamente no retorno desses pesquisadores. Planeja-se, com a chegada dessa nova leva de cientistas que estavam em contato direto com a alta tecnologia dos países desenvolvidos, a solução dos diversos problemas de

33 O Estado de São Paulo, 19 nov. 1972. 
infraestrutura, assim como a realização de projetos voltados a tecnologias adaptadas as necessidades nacionais (GUIMARÃES, 1985).

O reflexo dessa conjuntura é claramente percebido no momento de constituição do corpo docente da Unicamp. Conforme pudemos conferir em nossa pesquisa, essas iniciativas foram determinantes para a incorporação de um grupo de engenheiros e físicos, que ao final da década de 1960 trabalhavam nos Estados Unidos, no Bell Laboratories, e que a partir de então passaram a fazer parte do Instituto de Física Gleb Wataghin (IFGW/Unicamp).

Um dos líderes desse grupo, que negociou a vinda desses cientistas para o Brasil, foi o físico Rogério Cezar de Cerqueira Leite. Junto ao seu colega, Sérgio Porto, que além de pesquisador no Bell Laboratories, também era professor na Universidade do Sul da Califórnia (USC), receberam diversas visitas de embaixadores, e até a visita do então senador da ARENA, Arnon de Melo. O objetivo dessas reuniões era o de apresentar toda a estrutura de financiamento e apoio planejada pelo governo federal, abrindo as portas das instituições de pesquisa e universidades a esses pesquisadores ${ }^{34}$.

Instigados pela possibilidade de retornar ao país, e de alguma maneira tocados pelo otimismo nacionalista disseminado pelo regime militar, o grupo de cientistas ligados ao Bell Laboratories procurou em um primeiro momento se inserir no Instituto de Física da USP (IFUSP). O instituto se mobilizava para receber esses pesquisadores graças ao apoio de professores de renome dessa unidade, como Mário Schenberg e Oscar Salla. Entretanto tal proposta não foi levada adiante devido à interferência do então reitor, Alfredo Buzaid ${ }^{35}$, que não via com bons olhos a chegada desses cientistas.

Nesse ínterim, percebendo a janela de oportunidade aberta, Zeferino Vaz abriu negociação com o grupo e conseguiu atrair esses pesquisadores para a Unicamp ${ }^{36}$. Poucos anos depois, das iniciativas promovidas por esse grupo surgiria a espinha dorsal do polo tecnológico de Campinas.

\footnotetext{
${ }^{34}$ Entrevista com Rogério Cezar de Cerqueira Leite.

35 Idem.

${ }^{36}$ Entrevista com Zeferino Vaz.
} 
Entre 1970 e 1971, os professores, Rogério Cezar de Cerqueira Leite, Sérgio Porto, José Ellis Ripper, e outros colegas associados, foram contratados para a universidade. Ingressaram no Instituto de Física, em sua grande maioria atuando no Departamento de Estado Sólido e Ciência dos Materiais. A partir das pesquisas e ações promovidas por esse grupo a estrutura do polo tecnológico começou a se desenvolver.

Com o início dos trabalhos do Departamento de Estado Sólido e Ciências dos Materiais, diversas pesquisas tiveram início dentro da área de especialização de cada um desses cientistas. Foram privilegiadas principalmente projetos na área de semicondutores e lasers. O objetivo desses trabalhos era o de replicar pesquisas e tecnologias que os pesquisadores tiveram contato durante o período em que estiveram no Bell Laboratories ${ }^{37}$.

Um dos primeiros empreendimentos científicos que ganhou destaque nesse momento foi a pesquisa voltada a análise das possibilidades e uso de microlasers para a telecomunicação. Esse trabalho foi liderado por José Ellis Ripper, que contava com a colaboração de pesquisadores ligados a universidades estrangeiras, como Navim Ratel, do Instituto de Tecnologia da Califórnia - Estados Unidos (CalTech) e Philippe Brosson, da Universidade de Grenoble - França (UGA) ${ }^{38}$.

A partir desse grupo de pesquisas, se constituiria o Laboratório de Pesquisas em Dispositivos (LPD) no Instituto de Física da Universidade de Campinas. A equipe liderada pelo professor Ripper começou a desenvolver o equipamento de microlaser, os cristais semicondutores e toda a tecnologia embarcada ainda no ano de $1971^{39}$.

No cerne dessa iniciativa estava o objetivo de tornar o Brasil autossuficiente em uma tecnologia que se mostrava com alto potencial de ser aplicada em um futuro próximo. Em depoimento a imprensa, o então diretor do Instituto de Física, Rogério C. de Cerqueira Leite, afirmou:

O que se pretende fazer, e já se faz na Unicamp, é inicialmente auxiliar o complexo fabril a assimilar a tecnologia que nos permitirá a produção nacional

\footnotetext{
37 O Estado de São Paulo, 19 nov.1972.

${ }^{38}$ O Estado de São Paulo, 26 nov.1971.

${ }^{39}$ Folha de S. Paulo, 27 mar. 1982.
} 
no gênero. Reconhecemos naturalmente que isso não se faz em meses, mas sim em anos, e que outros grupos especializados deverão se formar, com grande sacrifício econômico para a nação ${ }^{40}$.

A ideia geral do programa é definida por Cerqueira Leite como "um meio de defesa para o Brasil, que em desenvolvimento, tem na pesquisa uma boa proteção ${ }^{41 " .}$

Ainda sobre a necessidade de um alto investimento inicial, o cientista justifica:

O desenvolvimento se faz inicialmente por assimilação de tecnologia e, subsequentemente, por produção própria de tecnologia. Na maior parte dos setores tecnológicos o Brasil está na primeira fase. A transição para a segunda é lenta e dispendiosa ${ }^{42}$.

Os depoimentos citados acima são interessantes na medida em que demonstram que logo no início da década de 70 o ideal desenvolvimentista já era mobilizado pela comunidade científica brasileira. Ao enunciar os termos desse processo, o representante desse grupo de cientistas, inclusive, adapta o seu discurso para soar próximo aos termos enunciados pela Doutrina de Segurança Nacional. Afirmar que a P\&D tem um papel a cumprir na defesa e desenvolvimento do país, em uma conjuntura onde a Segurança Nacional era o suporte ideológico de toda estrutura de Estado vigente, não parece arbitrário. Tal discurso aponta como parte da academia procurou mobilizar as engrenagens do poder para conseguir colocar em marcha projetos voltados a C\&T.

O esforço concentrado desses intelectuais era o de produzir um campo de pesquisa científica e tecnológica autenticamente nacional em concorrência com o desenvolvimento tecnológico do exterior. Para fazer isso, a escolha pela comunicação por laser não foi fortuita. O entendimento da época era de que por ser uma tecnologia relativamente nova, a defasagem tecnológica do país naquele momento era mínima, podendo ser superada graças à estrutura de P\&D que estava sendo criada ${ }^{43}$.

Para avaliarmos o engajamento da academia científica brasileira com o processo desenvolvimentista planejado pelo regime militar é preciso cautela. Defender a meta

\footnotetext{
${ }^{40}$ O Estado de São Paulo, 26 nov. 1971.

${ }^{41}$ Idem.

${ }^{42}$ Idem.

${ }^{43}$ Idem.Entrevista com José Ellis Ripper.
} 
desenvolvimentista não significa necessariamente apoiar a ideologia autoritária e conservadora sustentada pelo regime militar. Pelo contrário, muitos dos cientistas e intelectuais que se mobilizam nesse processo estão principalmente voltados ao ideal do desenvolvimento da C\&T nacional, que tinha considerável tradição no Brasil.

Corroboram com essa tese os diversos artigos assinados por Cerqueira Leite em editoriais no jornal Folha de São Paulo. Nesses textos, o autor ataca em inúmeras ocasiões o "entreguismo" de parte do governo perante as investidas das multinacionais estrangeiras e a insuficiente defesa dos interesses nacionais no campo da economia e ciência $^{44}$.

Percebemos que esses intelectuais repudiam enfaticamente a opressiva ideologia autoritária defendida na Doutrina de Segurança Nacional ${ }^{45}$. Entretanto, não se pode negar a ambivalência dessa posição, pois ao mesmo tempo em que rejeitam o caráter conservador do regime militar, se inserem ativamente na cruzada desenvolvimentista. A impressão que nos fica é de que para os intelectuais que conviviam com esse contexto político delicado, a escolha pela ciência e a tecnologia, e a defesa da elevada meta do desenvolvimento econômico, justificariam os eventuais descaminhos percorridos nesse processo.

Cabe também lembrar que o início da década de 1970 corresponde ao período do chamado "Milagre Brasileiro". Nessa conjuntura não foram poucos os que realmente se entusiasmaram com as possibilidades de crescimento do país. O surgimento do Brasil Potência, além de uma aposta do governo militar, era um sentimento quase palpável Cabe citar uma análise que aponta com clareza essa questão:

Até os brasileiros desgostosos com o governo autoritário orgulhavam-se com a evidência de que o país estava realmente em franca ascensão. Quaisquer que fossem suas imperfeições políticas, o Brasil estava se aproximando do status

\footnotetext{
${ }^{44}$ Como membro do conselho editorial do jornal Folha de São Paulo, Rogério C. de Cerqueira Leite produziu quantidade significativa de editoriais e artigos. Sobre o tema em questão citamos as seguintes edições desse veículo de imprensa: Folha de S. Paulo, 08 jul. 1976; Folha de S. Paulo, 19 nov. 1978; Folha de S. Paulo, 12 ago. 1979; Folha de S. Paulo, 06 nov. 1979; Folha de S. Paulo, 02 fev. 1970; Folha de S. Paulo, 05 abr. 1981; Folha de S. Paulo, 21 abr. 1981.

${ }^{45}$ Entrevistas com José Ellis Ripper; Rogério Cezar de Cerqueira Leite; Saul Gonçalves d’Ávila.
} 
internacional em ritmo mais rápido do que muitos ousaram esperar no início dos anos 60. Os sinais eram tranquilizadores (SKIDMORE, 1988, p.282).

Para parte considerável dos intelectuais nacionalistas, viver esse período e não contribuir com os projetos desenvolvimentistas era quase inconcebível. Tais pesquisadores tinham dedicado largos anos de sua formação em prol do aprimoramento da estrutura científica do país. Nesse contexto, o projeto desenvolvimentista passou a representar a oportunidade de uma geração conseguir realizar projetos largamente cultivados $^{46}$.

O Estado, ciente da oferta de uma mão de obra qualificada e imersa na ideologia nacionalista, incluiu tal material humano em sua estrutura desenvolvimentista. Ao mesmo tempo em que os veículos de comunicação, que naquela conjuntura estavam intimamente ligados aos interesses da ditadura militar (SKIDMORE, 1988), garantiram a divulgação positiva de tais iniciativas.

A construção social da ideia do cientista aliado ao desenvolvimento nacional vai ser formada ao se enfatizar que a competência e alta tecnologia estavam a serviço das necessidades do país. Em nossa pesquisa identificamos que a imprensa teve um papel de destaque na vulgarização desse conceito, publicando semanalmente artigos sobre tais questões.

$\mathrm{Na}$ matéria de jornal na qual se descreve os trabalhos realizados no laboratório do Departamento de Estado Sólido e Ciências de Materiais ${ }^{47}$, José Ellis Ripper, o coordenador da pesquisa em microlaser, futuro responsável pelo desenvolvimento da tecnologia em transmissões em fibras óticas, é apresentado como um cientista que, além da competência e erudição inquestionáveis, também se mostrava capaz de usar da criatividade e improvisação necessárias as condições do desenvolvimento de pesquisas em alta tecnologia no território nacional.

Para ilustrar essa proposição, o repórter descreve o ambiente do laboratório e a atuação do cientista. Ao apresentar os procedimentos de realização de uma complexa experiência com raio laser, relata como uma solução inusitada foi encontrada para

\footnotetext{
${ }^{46}$ Entrevista com Saul Gonçalves d'Ávila.

${ }^{47}$ O Estado de São Paulo, 26 nov. 1971.
} 
resolver um intricado problema que atrapalhava o andamento dos trabalhos, o uso de um simples secador de cabelos. O título da reportagem também transmite esse ideal de autossuficiência e adaptabilidade própria do brasileiro -"Dificil é o ar condicionado" na frase temos uma referência espirituosa ao fato de que o pesquisador carregava para todos os lados o manual de instruções do ar condicionado do laboratório, equipamento que se recusava a funcionar corretamente. Essa era a grande preocupação do cientista diligente, conforme o repórter ${ }^{48}$. A pesquisa e desenvolvimento da mais alta tecnologia em comunicações da época era algo relativamente fácil para a equipe.

Podemos propor algumas explicações para o uso de tais inferências. Em um país que ainda não tinha formado uma tradição de pesquisa em alta tecnologia - e ao propormos essa premissa não estamos ignorando os enormes esforços empreendidos pelos cientistas precursores das décadas anteriores, e sim assinalando ao fato reconhecido pela historiografia de que o campo da C\&T nas décadas anteriores aos anos 60 era fragmentário (MOTOYAMA, 2004) - e devido aos altos custos envolvidos, era preciso preparar o público para as potencialidades e particularidades da atividade científica.

Apresentar a competência inquestionável de um pesquisador brasileiro com experiência na maior instituição de pesquisa do mundo, o Bell Laboratories, e descrever a maneira segura e confiante com que adapta seus conhecimentos às particularidades nacionais, é uma forma inteligente de se colocar essa questão. A construção do Brasil Potência forçosamente não poderia prescindir da habilidade e sofisticação que o cientista em questão apresentava. Essa é a conclusão inevitável do resultado da reportagem $^{49}$.

Ao mesmo tempo em que o conteúdo tecnológico é utilizado para seduzir a imaginação do leitor, também serve como argumento justificador para o público, que em última instância estava financiando essa custosa aposta. Conforme lembrava Cerqueira Leite em sua fala, a população inevitavelmente sofreria com esse sacrifício econômico. Apresentando a aposta do desenvolvimentismo tecnológico, ressalta-se que,

\footnotetext{
48 Idem.

${ }^{49}$ O Estado de São Paulo, 26 nov. 1971.
} 
apesar dos sacrifícios, ao menos a população poderia se sentir despreocupada quanto aos resultados do empreendimento, pois a tarefa tinha sido entregue em boas mãos.

De fato, o resultado desse investimento logo começou a aparecer. O Departamento de Estado Sólido e Ciência dos Materiais aprofundava consistentemente suas pesquisas teóricas e experimentais sobre os fenômenos ópticos e sobre materiais semicondutores. Nesse meio tempo, os cientistas envolvidos nessas pesquisas cogitavam como os resultados dos trabalhos poderiam ser utilizados no desenvolvimento de equipamentos de telecomunicações. Tais descobertas receberam divulgação da grande mídia, que ao anunciar os constantes avanços das pesquisas, resgatava a origem do processo na decisão do reitor Zeferino Vaz em repatriar os cientistas brasileiros no exterior ${ }^{50}$.

Em 18 de julho de 1973, graças às iniciativas do professor Ripper, a Unicamp assinou um convênio com a Telebrás no qual se procurou realizar um dos objetivos do Plano Básico de Desenvolvimento Científico e Tecnológico, o aprimoramento da tecnologia em telecomunicações.

A contribuição do Laboratório de Pesquisas em Dispositivos seria aprofundar as investigações que estavam em andamento sobre o uso de lasers e semicondutores. Além de transferir o resultado dessas pesquisas para a Telebrás desenvolver industrialmente equipamentos de telecomunicações baseados nessas tecnologias. Conforme anunciado na época, a equipe de pesquisadores desenvolveria a tecnologia que tornaria viável economicamente a comunicação por fibras óticas no país ${ }^{51}$.

A partir de 1974, o Ministério das Telecomunicações e a Telebrás começaram a planejar a criação de uma instituição voltada a P\&D em telecomunicações. A cidade de Campinas tornou-se atrativa graças ao bom andamento do convênio assinado no ano anterior e às gestões junto aos órgãos decisórios promovidas pelo professor Ripper e o reitor Zeferino Vaz. Dispostos a atrair essa instituição de pesquisa para a cidade, esses acadêmicos procuraram o então Ministro das Comunicações, Euclides Quandt de

\footnotetext{
${ }^{50}$ O Estado de São Paulo, 18 nov. 1972; Folha de S. Paulo, 06 dez. 1980; Folha de S. Paulo, 03 jul. 1982; Folha de S. Paulo, 27 mar. 1982

${ }^{51}$ O Estado de São Paulo, 18 jul. 1973.
} 
Oliveira, e o presidente da Telebrás, o general José Antônio de Alencastro e Silva, convencendo-os da viabilidade da instalação do centro de pesquisa em Campinas ${ }^{52}$.

A argumentação utilizada tanto enfatizou a qualidade das instituições de pesquisa atuantes na cidade, em especial o êxito alcançado pelo convênio da Telebrás com a Unicamp, quanto a estrutura urbana e industrial favorável ${ }^{53}$. Tal argumentação fazia muito sentido, pois a cidade, nesse momento, favorecia-se da crescente capacidade do setor de C\&T e P\&D, ao mesmo tempo em que herdara de seu legado histórico, conforme vimos na primeira parte desse capítulo, o processo de ordenação urbana e estruturação da indústria. Tais atributos despontavam como predicados inegáveis.

Em 1976, a Telebrás instalou em Campinas o Centro de Pesquisa e Desenvolvimento Padre Roberto Landell de Moura (CPqD). A partir de 1977, a pesquisa que vinha sendo realizada na Unicamp sobre o uso de fibras de vidro na transmissão da comunicação com laser começou a ser transferida para o CPqD. Doravante, a instituição deveria desenvolver o processo industrial de produção dessa tecnologia e transmitir esse conhecimento para empresas do setor tecnológico. Em 1979, a universidade começou o processo de transferência da tecnologia de produção dos lasers ${ }^{54}$.

Os resultados do convênio com a Telebrás não ficaram restritos as contribuições do Instituto de Física. Podemos citar também a atuação do Departamento de Engenharia Elétrica, que graças às equipes coordenadas pelos professores Rege Scarabucci e Dalton Soares Arantes, produziram diversos sistemas de transmissão de comunicação, tanto sistemas analógicos, quanto sistemas digitais, inclusive desenvolveram equipamentos para a transmissão de comunicação por fibras óticas ${ }^{55}$.

Na Faculdade de Engenharia Civil, Arquitetura e Urbanismo (FEC/Unicamp), a área de materiais, coordenada pelo professor Maurício Prates de Campos Filho, desenvolveu pesquisas no âmbito da química dos silanos. Uma das necessidades da Telebrás era a de absorver a tecnologia de fabricação desse componente químico para

\footnotetext{
${ }^{52}$ Entrevistas com José Ellis Ripper; Zeferino Vaz.

${ }^{53}$ Entrevista com Saul Gonçalves d'Ávila.

${ }^{54}$ Folha de S. Paulo, 25 ago. 1979.

${ }^{55}$ Folha de S. Paulo, 06 dez. 1980.
} 
realizar a produção industrial de equipamentos eletrônicos. A equipe liderada pelo professor Campos Filho encaminhou o desenvolvimento dessa tecnologia ${ }^{56}$.

Além dos inúmeros desenvolvimentos tecnológicos, dos quais citamos alguns, o convênio com a Telebrás também foi responsável pela formação de muitos mestres e doutores graças aos programas de pesquisa que se iniciaram. Até o ano de 1980, já se contava trinta dissertações de mestrado e três teses de doutorado defendidas graças a essas pesquisas ${ }^{57}$. Esses números eram consideráveis para a época, principalmente tendo em conta a urgente necessidade de expansão da pesquisa em C\&T, especialmente nos setores de infraestrutura e tecnologia (MOTOYAMA, 2004).

Ainda sobre a estrutura de formação científico/acadêmica, é preciso ressaltar o papel da Pontifícia Universidade Católica de Campinas (PUC-Campinas), que principalmente com os cursos de engenharia, formou profissionais que tiveram atuação nas instituições de pesquisa tecnológica e desenvolvimento do polo da cidade.

Além do $\mathrm{CPqD}$, a cidade de Campinas incorporou outras instituições voltadas a pesquisa. Em 1963, graças à iniciativa do governo do Estado de São Paulo, instalou-se na cidade o CPTA (Centro Tropical de Pesquisas e Tecnologia de Alimentos), atual ITAL (Instituto de Tecnologia de Alimentos). O objetivo do trabalho dessa instituição era promover atividades de $\mathrm{P} \& \mathrm{D}$ e assistência tecnológica para empresas do setor alimentício.

Também se destacou entre as instituições de pesquisa da cidade o Centro de Tecnologia da Informação Renato Archer (CTI). Tal instituição começou a ser planejada no início dos anos 80. A escolha da cidade novamente se deu graças ao andamento das pesquisas em semicondutores, promovida pelo Instituto de Física, e a presença de profissionais capacitados formados nessa instituição.

José Ellis Ripper, com apoio da UNICAMP, conseguiu atrair investimentos para a criação de uma instituição voltada a P\&D e fabricação de circuitos integrados em

\footnotetext{
${ }_{56}^{56}$ Entrevista com Saul Gonçalves d'Ávila.

${ }^{57}$ Folha de S. Paulo, 06 dez. 1980.
} 
Campinas $^{58}$. As primeiras atividades da instituição começaram em 1983, e na estreia dos trabalhos da fábrica de circuitos integrados do CTI, em depoimento para a imprensa, o então diretor geral da instituição, José Rubens Dória Porto, e o diretor do Instituto de Microeletrônica, Carlos Inácio Mammana, projetavam a fabricação de circuitos integrados de alta confiabilidade. Imaginavam em pouco tempo ter condições de produzir esse componente eletrônico em larga escala, inclusive fornecendo essa tecnologia para o uso em computadores de grande porte e equipame ntos militares ${ }^{59}$.

Até agora pudemos perceber o surgimento de uma estrutura voltada a P\&D graças à presença ostensiva do Estado. Ou seja, todas as instituições voltadas a P\&D e C\&T apresentadas até esse momento surgiram como iniciativa do Governo Federal, e no caso do ITAL, por intermédio do governo do Estado de São Paulo.

Entretanto sabemos que para se configurar um polo tecnológico, além do necessário ambiente de pesquisa, condição suprida pelas universidades e instituições de P\&D atuantes da cidade de Campinas, é necessária a interação com o setor produtivo. Essa interação era facilitada pelo $\mathrm{CPqD}$ e pelo CTI, conforme vimos, e também por estruturas de apoio e incentivo ao desenvolvimento de indústrias tecnológicas que começam a surgir no final da década de 70 graças a iniciativa individual de alguns professores da UNICAMP. Nesses casos, não vemos a presença do Estado, e sim a ação particular de sujeitos ligados a C\&T na cidade de Campinas.

Sobre essas estruturas de apoio às indústrias tecnológicas estamos nos referindo ao surgimento da CODETEC (Companhia de Desenvolvimento Tecnológico) e da CIATEC (Companhia de Desenvolvimento do Polo de Alta Tecnologia de Campinas). Ambas as instituições surgem a partir da avaliação feita por alguns pesquisadores e professores da Unicamp da necessidade de espaços que permitissem a consolidação de algumas iniciativas individuais que estavam proporcionando o surgimento de pequenas indústrias de tecnologia na cidade ${ }^{60}$. A ideia por trás da criação dessas instituições era garantir o desenvolvimento dessas pequenas empresas, mais ou menos como o Stanford Industrial Park atuou no início das indústrias do Vale do Silício.

\footnotetext{
${ }^{58}$ Entrevista com José Ellis Ripper.

${ }^{59}$ Folha de S. Paulo, 15 out. 1983.

${ }^{60}$ Entrevista com Rogério Cezar de Cerqueira Leite.
} 
Inicialmente, a meta de consolidação da indústria tecnológica na cidade foi elaborada a partir da ideia da construção de uma incubadora de projetos industriais. Tal conceito, empregado largamente na atualidade, nos anos finais da década de 70 era uma ideia nova que precisava ser experimentada. O professor, Rogério C. Cerqueira Leite, do Instituto de Física, e Aldo Viera da Rosa, então professor da Universidade de Stanford, começaram a elaborar o projeto no qual imaginavam uma estrutura dentro do Campus da Unicamp capaz de absorver e desenvolver projetos tecnológicos que estavam na fase de pesquisa dentro das unidades da universidade, transformando tais projetos em potenciais empresas ${ }^{61}$.

A partir de 1977, Cerqueira Leite começou as tratativas no sentido de instituir essa incubadora de indústrias, que foi nomeada como Companhia de Desenvolvimento Tecnológico (CODETEC). Nesse momento, negociava-se com a Finep, que entraria como uma das financiadoras do projeto, e naquele momento o professor Cerqueira Leite entendia ter boas perspectivas de conseguir esse apoio financeiro, já que José Pelúcio Ferreira, presidente da instituição, se mostrava empolgado com a ideia.

Nessa época, em depoimento ao CPDOC, Cerqueira Leite afirmou: "Eu não posso dizer que a Codetec foi feita para criar indústrias, parece muito pretensioso. Mas ela vai criar uma indústria, eu garanto. Vai ajudar a criar algumas indústrias para o país, vai acelerar o processo ${ }^{62 "}$.

Para presidência da CODETEC escolheram Aldo Viera da Rosa, e para o conselho de administração, convidaram diretores de grandes empresas brasileiras de capital nacional, como a Eletrometal e a Vilares, assim como alguns bancos ${ }^{63}$.

Os primeiros projetos que começaram a ser desenvolvidos pela CODETEC eram frutos dos trabalhos de um grupo de pesquisa que recebia financiamento da Finep para desenvolver estudos sobre energia alternativa na Unicamp. Cabe lembrar que a partir de 1973, uma das grandes preocupações do planejamento econômico do Brasil, era encontrar maneiras de impedir a fuga de divisas para o exterior. A alta do preço do

\footnotetext{
${ }^{61}$ Entrevista com Saul Gonçalves d'Ávila.

${ }_{63}^{62}$ Entrevista com Rogério Cezar de Cerqueira Leite..

${ }^{63}$ Entrevista com Saul Gonçalves d'Ávila.
} 
barril do petróleo consumia os recursos do país. Nessa conjuntura de crise, uma das respostas do governo foi apoiar a $\mathrm{P} \& \mathrm{D}$ de tecnologias voltadas a produção de energia alternativa no Brasil. Um dos órgãos financiadores dessa empreitada foi a Finep, e graças a disponibilidade de investimentos para esse setor, as universidades começaram a desenvolveram projetos dentro dessa linha de pesquisa (MOTOYAMA, 2004).

$\mathrm{Na}$ Unicamp, em resposta a demanda por pesquisas na área de energia, João Alberto Meyer, formou e passou a coordenar o Grupo de Energia, que se destacou na produção de pesquisas sobre energias renováveis e temas correlatos. Participavam desse grupo professores e alunos de diversas unidades da Unicamp.

Parte das pesquisas desenvolvidas pelo Grupo de Energia foi utilizada como base para projetos de desenvolvimento de produtos industriais pela CODETEC. Podemos citar as pesquisas sobre energia solar, que proporcionaram o desenvolvimento de coletores de energia solar para o aquecimento de água. Também as pesquisas sobre biomassa, que encontraram aplicações práticas no desenvolvimento de grandes secadores de grãos baseados no sistema de bioconversão. Outro exemplo que pode ser citado está nas pesquisas que investigavam o fenômeno de eletrólise da água. $\mathrm{Na}$ CODETEC, com a coordenação do professor Saul Gonçalvez d'Ávila, baseando-se nos resultados dos estudos sobre eletrólise, desenvolveram um módulo industrial utilizando essa tecnologia. Graças às potencialidades apresentadas naquele momento, o desenvolvimento desse equipamento atraiu uma linha de crédito financiada pela CESP (Companhia Energética de São Paulo), que se mostrou interessada em aprimorar essa tecnologia. Para concluir, imaginava-se também a aplicação de eletrolisadores para a fabricação de amônia. Tal projeto concebia a criação de grandes usinas que utilizariam hidrogênio eletrolítico para a fabricação desse composto. Esse projeto, imaginado por Aldo Viera da Rosa, nunca avançou além da fase de planejamento devido aos enormes custos com a usina e com a infraestrutura necessária ${ }^{64}$.

Estamos citando algumas das diversas tentativas de desenvolvimento de produtos voltados à substituição de energia. Desses projetos, algumas tecnologias foram materializadas no desenvolvimento de produtos industriais. Tais produtos, inclusive,

\footnotetext{
${ }^{64}$ Entrevista com Saul Gonçalvez d’Ávila.
} 
proporcionaram o aparecimento de algumas pequenas empresas, como, por exemplo, a Codesol, empresa especializada na produção de coletores de energia solar para aquecimento. Também podemos citar a Termoquip, empresa que se especializou na produção de grandes gaseificadores industriais. O elemento comum a essas indústrias é a produção de equipamentos simples, baseados em tecnologias que não exigissem grandes investimentos.

Além das pesquisas voltadas ao desenvolvimento de produtos na área de energia, na primeira metade da década de 1980, a CODETEC tentou incubar grandes projetos para áreas estratégicas da economia nacional. Podemos citar um projeto de uma fábrica de fibras óticas que seria construída na cidade, ou a investida no setor farmacêutico, projeto no qual se pretendia fabricar os fármacos utilizados na produção de medicamentos. A tentativa de se criar uma fábrica de fibras óticas não foi adiante devido à falta de investimentos privados e a concorrência de grandes companhias que se instalaram na cidade ${ }^{65}$. A produção de fármacos não avançou além do início da década de 1990, em parte devido à abertura de mercado promovida pelo governo Collor (1990 1992) e a concorrência com as grandes empresas farmacêuticas internacionais ${ }^{66}$.

A segunda iniciativa que tentou apoiar e estruturar o desenvolvimento de empresas de tecnologia na cidade foi o movimento de criação de um parque tecnológico planejado para ser instalado na área de intersecção entre a Unicamp e o CPqD.

Nos anos finais da década de 1970, e início dos anos 80, a área entre a universidade e a instituição de pesquisa da Telebrás ainda não estava ocupada. Graças à experiência de Aldo Viera da Rosa, em Stanford, Rogério C. Cerqueira Leite começou a elaborar um projeto de instalação de um parque tecnológico nas imediações da Unicamp inspirado no desenvolvimento das atividades do Stanford Science Park. Nessas primeiras elucubrações, imaginava-se um local para acolher as empresas de tecnologia que surgiriam como resultado das pesquisas que estavam sendo desenvolvidas pelo CPqD e Unicamp. Planejava-se uma situação onde o apoio da prefeitura permitiria que empreendedores e investidores pudessem implementar empresas de tecnologia. Essas

\footnotetext{
${ }^{65}$ Folha de S. Paulo, 15 ago. 1984.

${ }^{66}$ Entrevista com Rogério Cezar de Cerqueira Leite; Entrevista com Saul Gonçalvez d'Á vila.
} 
empresas se desenvolveriam graças à disponibilidade de terras a baixo custo subsidiadas pelo governo local - e a presença próxima das instituições de $P \& D$ que atuariam em colaboração com a indústria $\operatorname{local}^{67}$.

Esse projeto foi apresentado ao reitor Zeferino Vaz que apoiou a iniciativa junto à administração municipal ainda no ano de $1976^{68}$. Entretanto as conversas só conseguiram avançar na gestão do prefeito José Roberto Magalhães Teixeira.

Em 1981, o prefeito Magalhães Teixeira assinou o decreto 6619 delimitando o zoneamento da área no entorno da universidade para as indústrias tecnológicas. Conforme a justificativa apresentada no decreto, à presença próxima as instituições de pesquisa e universidades era uma condição fundamental para o bom encaminhamento de projetos que procurassem integrar as pesquisas desenvolvidas no âmbito da universidade e instituições de $\mathrm{P} \& \mathrm{D}$, com o setor produtivo. $\mathrm{O}$ projeto que está em questão era o de replicar a estrutura desenvolvida no Vale do Silício:

O Prefeito do Município de Campinas, usando das atribuições que the são conferidas pelo Decreto Lei Complementar $N^{\circ}$ 9, de 31 de dezembro de 1969, artigo $3^{\circ}$, inciso IX e artigo 39, incisos V e XX, a com fundamento no artigo 8.7.2.03 da Lei $\mathrm{N}^{\mathrm{o}}$ 1993, de 29 de janeiro de 1959 - Código de Obras e Urbanismo do Município de Campinas, e CONSIDERANDO que constitui atribuição do Município disciplinar o uso e ocupação do solo, através do zoneamento; CONSIDERANDO a necessidade de se adequar corretamente a localização das zonas comerciais, industriais e residenciais; CONSIDERANDO ser indispensável a reserva de uma região destinada a industria de tecnologia avançada, procedimento este adotado nos Estados Unidos, onde as sobressai o parque industrial da Universidade de Stanford, e nos países europeus; CONSIDERANDO que as industrias de alta tecnologia, como, por exemplo, de instrumentação, microeletrônica, informática, telecomunicações, etc., somente os desenvolvem satisfatoriamente nas proximidades dos centros de estudos e pesquisas;CONSIDERANDO que existe em Campinas uma área ideal à finalidade almejada, especialmente face à sua localização, vizinha da Universidade de Campinas - UNICAMP e da Pontifica Universidade Católica de Campinas - PUCC, DECRETA:

Art. $1^{\mathrm{o}}$ :A área abrangida pela linha perimétrica a seguir descrita e caracterizada passa a ser classificada como Zona Industrial: (...)

Art. $2^{\circ}$ :As construções situadas na área delimitada no artigo anterior somente poderão ser destinadas a industrias de avançada tecnologia.

Este decreto entra em vigor na data de sua publicação, revogadas as disposições em contrário.

Art. $3^{\circ}$ :Este decreto entra em vigor na data de sua publicação, revogadas as disposições em contrário.

Campinas, 19 de agosto de 1981.

\footnotetext{
${ }^{67}$ Entrevista com Rogério Cezar Cerqueira Leite.

${ }^{68}$ Folha de S. Paulo, 03 out. 1981; Entrevista com Rogério Cerqueira Leite.
} 
Além da lógica de concentração espacial dos meios de produção e conhecimento, conforme vemos no próprio texto da lei de zoneamento exposto acima, também se justifica o projeto recorrendo-se a argumentos que mobilizam a ideia do desenvolvimento econômico local e as pretensas vantagens ecológicas desse arranjo produtivo. Em depoimento a um veículo de comunicação, o prefeito Magalhães Texeira afirmou:

O município está interessado no projeto porque paralelamente aos benefícios às indústrias a cidade também ganharia com a criação de mais empregos e mais arrecadação, evitando-se também problemas ecológicos, pois as firmas não são poluentes ${ }^{69}$.

Com esse depoimento vemos a conjunção do pragmatismo planejador, que avalia o desenvolvimento da indústria local como fonte de arrecadação e emprego, com a utopia ligada ao desenvolvimento tecnológico. Imagina-se que a indústria eletrônica representava uma alternativa econômica altamente recomendável, pois essa indústria conciliaria as demandas do desenvolvimento com as necessidades ecológicas.

A partir desse depoimento, a conjunção dos motivos ecológicos e econômicos passou a ser utilizado como principal fio condutor das explicações em torno da criação dessa unidade produtiva. Nas reportagens veiculadas pela imprensa sobre desenvolvimento do parque tecnológico, que em 1981 era nomeado como Intercamp, recorreu-se a justificativas que utilizavam conteúdos centrados na aposta tecnológica, na busca por uma nova indústria não poluente e nos potenciais ganhos locais previstos nesse processo $^{70}$.

Apesar da inicial empolgação em torno do desenvolvimento de mais uma unidade produtiva voltada à alta tecnologia na cidade, o processo de instalação desse parque tecnológico se mostrou bem mais complicado que o imaginado.

Somente dois anos após o decreto da prefeitura zoneando a área urbana destinada a indústria tecnológica é que se estruturou a uma instituição responsável por

\footnotetext{
${ }^{69}$ Folha de S. Paulo, 14 jun. 1981.

70 Folha de S. Paulo, 14 jun. 1981; Folha de S. Paulo, 03 out. 1981; Folha de S. Paulo, 19 ag o. 1983; Folha de S. Paulo. 12 ago. 1985.
} 
coordenar a implementação das empresas no parque tecnológico imaginado. Criou-se assim, em 1983, o Centro de Indústrias de Alta Tecnologia. Esse projeto continuou em desenvolvimento até 1985, quando o CPqD, o CTI e a CPFL (Companhia Paulista de Força e Luz) ingressaram no planejamento do parque tecnológico, formando a Companhia de Desenvolvimento do Polo de Alta Tecnologia de Campinas (CIATEC). A CIATEC passou a ser gerida funcionalmente por uma empresa de sociedade anônima de economia mista (municipal e particular), a IMA (Informática dos Municípios Associados S/A), e a CODETEC (JOIA, 2000).

A nossa pesquisa identifica que muito da demora em se estruturar o projeto do parque tecnológico deveu-se a burocracia e interesses divergentes dentro do governo municipal ${ }^{71}$.

Ficou evidente a existência de antagonismos quanto aos rumos do projetado parque tecnológico no momento em que essa unidade econômica começou a se configurar em 1986. Comparando o projeto inicial com a estrutura instalada, percebe-se um contraste evidente. Ao invés de um espaço onde a pequena e média indústria poderiam se inserir, a unidade nomeada Polo I colocou a venda uma área que permitia a instalação de 49 grandes empresas, disponibilizando lotes de no mínimo $10.000 \mathrm{~m}^{2}$. Esses lotes foram vendidos a preço de mercado (JOIA, 2000).

Ou seja, a ideia de apoiar as iniciativas locais voltadas a projetos pioneiros de P\&D abriu espaço a um conceito articulado as necessidades das grandes empresas de tecnologia já consolidadas. O caráter especulativo desse empreendimento também foi detectado, pois os preços eram pouco acessíveis ao pequeno empreendedor ${ }^{72}$.

Mesmo a localização do Polo I fugiu da inicial configuração imaginada próxima a universidade. A área de instalação desse primeiro parque tecnológico se situou próximo ao CTI, que geograficamente encontrava-se a uma distância de aproximadamente 10 quilômetros da região inicialmente projetada. A área próxima à universidade só foi ocupada nos anos 90, quando a CIATEC abriu o empreendimento que foi nomeado como Polo II.

\footnotetext{
${ }^{71}$ Entrevista com Rogério Cezar Cerqueira Leite.

${ }^{72}$ Entrevista com Rogério Cezar de Cerqueira Leite.
} 
Do ponto de vista quantitativo, conforme extensa pesquisa realizada pelo pesquisador Paulo Roberto Joia, considerando as indústrias instaladas nas unidades Polo I e Polo II, a CIATEC, até o final da década de 1990, não conseguiu atrair mais de 20 empresas para os parques tecnológicos sobre sua administração (JOIA, 2000).

As dificuldades em desenvolver os parques tecnológicos geridos pela CIATEC podem ser relacionadas principalmente a dois fatores. Em primeiro lugar, as grandes indústrias de eletrônica consideraram mais proveitoso, do ponto de vista econômico, se instalar em outras áreas da cidade. Por trás disso está o fato de que o padrão de interação dessas empresas com a UNICAMP se transformou substancialmente na década de 1990. Estar próximo à universidade deixou de ser uma vantagem. Veja a análise de Joia (2000, p.179) sobre essa questão:

Pelo que pôde ser analisado, constatou-se que, na atualidade, os institutos de pesquisa estabelecem um relacionamento muito mais constante e estreito com as empresas industriais, do que aquele que estas mantêm com as universidades. (...) A partir de 1990, com a nova política industrial e do comércio exterior voltada para a inserção competitiva internacional do país, tanto os centros de pesquisa e desenvolvimento das telecomunicações $(\mathrm{CPqD})$ quanto os da informática (CTI) passaram por uma nova forma de atuação, visando a geração de tecnologias diretamente transferíveis ao mercado. Como a produção de equipamentos e os serviços de telecomunicações foram privatizados e desnacionalizados, diminuiu, principalmente, a demanda do setor de pesquis a de novos produtos e processos, restando, para os institutos, a prestação de serviços tecnológicos à indústria e ao reformulado sistema de telecomunicações brasileiro.

Em segundo lugar, os preços pouco atrativos dos lotes impediram a instalação de empreendedores dispostos a desenvolver novas indústrias tecnológicas na área. Soma-se a falta de investimento de risco para projetos tecnológicos no país (LIMA, 1997), e temos boa parte da explicação dos fatores que levou ao insucesso dessa iniciativa.

Se o desenvolvimento da CIATEC foi prejudicado pela desarticulação entre planejadores, burocracia municipal e o setor produtivo vemos que a própria estrutura de C\&T, que surgiu graças as ações do governo federal na cidade, viu-se debilitada nos anos em que o Modelo Brasileiro de Desenvolvimento, e o próprio regime militar, entraram em decadência. 
Os sinais de esgarçamento do apoio federal as iniciativas locais já eram percebidos, mesmo que de uma maneira indireta, ainda no fim da década de 1970. A percepção de uma crise estrutural pode ser notada em um depoimento dado a imprensa por Rogério C. Cerqueira Leite, em setembro de 1979. Ao participar de uma mesa de debates sobre a crise na UNICAMP causada por cortes orçamentários promovidos pelo governador Paulo Maluf, Cerqueira Leite ponderou que a excessiva dependência do governo estava condicionando limites estreitos às possibilidades da Universidade. Também citou a inexistência de uma iniciativa privada vigorosa como um entrave a avanços mais significativos na relação entre as universidades e o setor produtivo. Descrevendo esse contexto, o intelectual apresenta as dificuldades que estava enfrentando para consolidar a CODETEC:

\footnotetext{
Isso não funcionou (referindo-se à CODETEC) porque os empresários estão mais ligados ao governo, de quem dependem, do que às universidades. Quando a universidade surgiu no mundo servia apenas a uma elite de intelectuais. Atualmente, apesar de suas novas funções, ela tem sempre um pacto com o poder não explícito, mas que existe ${ }^{73}$.
}

Se retomarmos a análise desse capítulo, veremos que o pacto não explícito com o poder permitiu o surgimento de uma considerável estrutura de P\&D na cidade de Campinas. Conforme vimos, essa estrutura foi criada graças à articulação dos projetos da universidade com a política desenvolvimentista do regime militar. Entretanto, quando o ufanismo propagador da ideia do "Brasil Potência" viveu seu crepúsculo, e o planejamento econômico do governo precisou lidar com uma situação de grave crise econômica, nesse momento, o governo abriu mão de qualquer pretensão desenvolvimentista. A partir de então, o pacto não explícito com o poder começou demonstrar suas facetas negativas.

Em uma situação de grave crise econômica, o regime militar precisou abandonar as pretensões desenvolvimentistas e se voltar para o pragmatismo de uma realidade pouco favorável. O objetivo do planejamento econômico passou a ser modesto, garantir um término de governo estável. Para cumprir essa meta, o regime militar submeteu-se

\footnotetext{
${ }^{73}$ Folha de S. Paulo, 20 set. 1979.
} 
aos ditames do FMI, desmobilizando toda a estrutura desenvolvimentista que estava em curso (SKIDMORE,1988).

Campinas ainda colheu dividendos de um momento anterior, quando inaugurou projetos que tinham começado em uma conjuntura econômica mais favorável. A inauguração do CPQd e do CTI aconteceu nesse contexto. Mas esses foram os últimos lampejos do projeto desenvolvimentista que mobilizou grande parte da imaginação e sonhos da década anterior.

O próprio presidente Figueiredo confirmou esse prognóstico quando visitou CPQd, em 1980, nessa visita confidenciou aos repórteres presentes:

\footnotetext{
"O que falta para o Brasil são os recursos, pois dentro de três anos essa rapaziada da Telebrás estará dominando a tecnologia, mas não temos recursos para implementar as necessidades da telecomunicações ${ }^{74 ”}$.
}

Ao ser questionado se era viável aumentar o grau de prioridade para a $\mathrm{P} \& \mathrm{D}$, o então presidente se esquivou: 'Não é possível porque todos os setores são prioritários $" 75$.

A inconstância de investimentos, que começava a transparecer no início da década de 1980, a partir de então, aos poucos, se tornou uma norma. A desmobilização do sistema de C\&T foi tão significativa que meses após o fim do regime militar, uma das principais instituições de $\mathrm{P} \& \mathrm{D}$ da cidade de Campinas, o CTI, não tinha nem confirmação da dotação orçamentária que dispunha para concluir o ano de 1985. Naquele momento, essa instituição empregava mais de trezentas pessoas. Entre esses funcionários estavam presentes vinte doutores, trinta e seis mestres, e diversos técnicos de nível médio e superior. Além de pagar seus funcionários, a instituição estava responsável por dar andamento a vinte projetos voltados a $\mathrm{C} \& \mathrm{~T}^{76}$.

Vivendo tal situação de precarização, a atividade $\mathrm{P} \& \mathrm{D}$, que nos anos anteriores podia ter se inspirado no pensamento utópico, a partir de então passou a viver as agruras

\footnotetext{
${ }^{74}$ Folha de S. Paulo, 28 nov. 1980.

75 Idem.

${ }^{76}$ Folha de S. Paulo, 18 set. 1985.
} 
da restrição de gastos. Simplesmente não havia recursos para a realização das atividades científicas no país.

A Finep, uma das grandes fomentadoras dos projetos desenvolvidos em Campinas, nessa conjuntura, restringiu grande parte dos investimentos destinados a P\&D. Em conversa com o um membro da administração dessa instituição, o diretorgeral do CTI, Miguel Teixeira de Carvalho, ouviu o seguinte pensamento: "Se der muito dinheiro a um órgão de pesquisa, ele acaba pesquisando máquina de desentortar banana $^{77}$. Essa frase é mais do que exemplar de um novo momento onde se abandonou completamente a perspectiva de apoio às potencialidades transformadoras da C\&T.

A obrigatória mudança de curso pela qual passaram as instituições de $P \& D$ da cidade no início da década de 1990, conforme aponta a pesquisa de Paulo Roberto Joia (JOIA, 2000), já era percebida nessa circunstância. Em depoimento sobre as condições do CTI, nesse ambiente de restrição econômica, o diretor-geral dessa instituição, afirmou:

Com pouco dinheiro só se pode fazer uma solução se alguém precis a dela. Então o CTI vai precisar trabalhar em conjunto com outros órgãos e empresas. Se o trabalho proposto interessa aos outros aparecem recursos ${ }^{78}$.

Outro indicador que podemos usar como referência do grau de desmobilização que a estrutura de C\&T estava enfrentando, está na formação de um sindicato de trabalhadores prestadores de serviços para instituições de C\&T.

Em 1990, a cidade de Campinas funda e torna-se sede do Sindicato de Trabalhadores de Pesquisa, Ciência e Tecnologia do Estado de São Paulo (SINTPq). Nesse momento, a principal preocupação da categoria era o temor de possíveis ameaças de desemprego e desestruturação das instituições de P\&D públicas. No horizonte de curto prazo, algumas das instituições de pesquisa da cidade foram privatizadas ou passaram por rigorosos processos de contensão de gastos e consequentes demissões (JOIA, 2000).

\footnotetext{
${ }^{77}$ Folha de S. Paulo, 18 set. 1985.

${ }^{78}$ Idem.
} 
No final desse processo vemos que a pesquisa em C\&T passou a ser planejada longe das pretensões desenvolvimentistas. A partir de então, um novo arranjo econômico passou a impor suas demandas e compromissos. Nesse contexto, o polo tecnológico de Campinas se reconfigurou para atuar dentro dessa nova lógica.

\section{Capítulo 3 - DA TOTALIDADE AO PARTICULAR: VISÕES SOBRE O POLO TECNOLÓGICO DE CAMPINAS ATRAVÉS DAS LENTES DA HISTÓRIA ORAL}

\subsection{A História Oral e a Análise Historiográfica}

Devido à particularidade do objeto de estudo dessa dissertação, um dos procedimentos de pesquisa que utilizamos em nosso trabalho foi o uso da técnica da entrevista. Utilizamos a história oral principalmente com o objetivo de registrar informações que podemos qualificar como tocante à experiência humana, experiência essa, que por sua singularidade, muitas vezes escapa de outros tipos de registros (FREITAS, 2006). Junto à técnica da entrevista, articulamos outros procedimentos de pesquisa, conforme parte da historiografia sobre o uso do método da história oral propõe:

Escrever um livro que utiliza evidência oral, quer sozinha quer junto com outras fontes, não requer, em princípio, muitas habilidades especiais além das necessárias para qualquer texto histórico. A evidência oral pode ser avaliada, julgada, comparada e citada paralelamente ao material de outras fontes (THOMPSON. 1992, p.305).

Quando definimos que um dos objetivos da análise realizada nessa dissertação era o de entender a atuação dos intelectuais/pesquisadores que ajudaram a desenvolver o polo tecnológico localizado em Campinas, percebemos que caso nos concentrássemos apenas nos resultados desse processo, através da análise da estrutura de $\mathrm{P} \& \mathrm{D}$ e indústria da região, não conseguiríamos entender elementos mais profundos que atuaram na formação dessa unidade técnico-produtiva; tal procedimento impediria principalmente 
de percebemos as características das visões e projetos individuais colocados na região. Dessa maneira, a fonte oral se mostrou extremamente elucidadora das particularidades e atuações particulares no evento em questão:

A maior potencialidade deste tipo de fonte é a possibilidade de resgatar o indivíduo como sujeito no processo histórico. Consequentemente, reativa o conflito entre liberdade e determinismo ou entre estrutura social e ação humana (FREITAS. 2006, p.50).

A comunidade acadêmica de Campinas, vivendo sobre os ditames do desenvolvimentismo conservador planejado pelo Estado, precisou responder às inúmeras demandas do governo, da estrutura acadêmica da universidade, da sociedade, e de seus próprios projetos profissionais e pessoais. Dessa maneira, o depoimento oral nos permitiu a observação de como esses inúmeros vetores se articularam em um projeto comum. Tal análise já foi descrita nos manuais de História Oral, nossa metodologia apenas adaptou essa técnica às nossas necessidades particulares:

Entrevistas de história oral podem ser usadas no estudo da forma como pessoas ou grupos efetuaram e elaboraram experiências, incluindo situações de aprendizado e decisões estratégicas. Essa noção é particularmente desenvolvida em textos alemães, onde recebe o nome de Erfahrybgsgeschichte (história de experiência), e aparece em combinação com a ideia de mudança de perspectiva (Perspektivenwechsel). Em linhas gerais, essas noções significam o seguinte: entender como pessoas e grupos experimentaram o passado torna possível questionar interpretações generalizantes de determinados acontecimentos e conjunturas (VERENA. 1990, p.25-26).

Ao mesmo tempo em que conseguimos aprender mais sobre as decisões e escolhas estratégicas realizadas, o depoimento oral também nos permitiu analisar particularidades que por vezes não eram expostas em nenhuma outra fonte documental, e principalmente nos ajudou a entender como demandas que eventualmente poderiam ser antagônicas puderam ser equalizadas dentro de um objetivo comum. Tal arranjo contraditório só pode ser explicado se considerarmos a própria dinâmica da experiência humana, que precisa adaptar sonhos e necessidades às condições econômicas, sociais e culturais que muitas vezes fogem da capacidade humana de transformação imediata. A demonstração desse processo de conformação de expectativas e projetos pode ser 
muitas vezes exposto através da técnica da entrevista, conforme a análise da historiografia sobre essa questão:

Acreditamos que a principal característica do documento de história oral não consiste no ineditismo de alguma informação, nem tampouco no preenchimento de lacunas de que se ressentem os arquivos de documentos escritos e iconográficos, por exemplo. Sua peculiaridade - e da história oral como um todo - decorre de toda uma postura com relação à história e as configurações sócio culturais, que privilegia a recuperação do vivido conforme concebido por quem viveu (VERENA. 1990, p.16).

Compete também a esse espaço discutir brevemente uma concepção antiquada quanto ao uso da fonte oral, que em alguns momentos pode ser tratada como inferior ao documento escrito, por conter uma parcela de subjetividade e parcialidade própria da memória do entrevistado. Sobre tal crítica citamos a análise a seguir:

\footnotetext{
Para alguns historiadores tradicionais, os depoimentos orais são tidos como fontes subjetivas por nutrirem-se da memória individual que, às vezes, pode ser falível e fantasiosa. No entanto, em História Oral o entrevistado é considerado, ele próprio, um agente histórico. Nesse sentido, é importante resgatar sua visão acerca de sua própria experiência e dos acontecimentos sociais dos quais participou. Por outro lado, a subjetividade está presente em todas as fontes históricas, sejam elas orais, escritas ou visuais. O que interessa em História Oral é saber por que o entrevistado foi seletivo ou omisso, pois esta seletividade temo seu significado. Além disso, a noção de que o documento escrito possui um valor hierárquico superior a outros tipos de fonte vem sendo sistematicamente contestada (FREITAS. 2006, p.69).
}

Percebemos nessa concepção de uso da fonte oral a pertinência de nosso projeto de entender como a comunidade acadêmica de Campinas se inseriu no Modelo Brasileiro de Desenvolvimento ao mobilizar as potencialidades da C\&T. O uso dessa técnica de análise histórica nos permitiu entender os pesquisadores envolvidos nesse projeto como sujeitos históricos que expressam suas intenções e visões de mundo através de seu trabalho e da emissão de opiniões (sejam escritas ou orais). Tais conteúdos podem ser analisados e qualificados, abrindo espaços para que a análise sobre essa conjuntura particular possa ser aprofundada. 
Ao mesmo tempo em que investigamos o conhecimento sobre as iniciativas que levaram ao surgimento de um polo tecnológico em Campinas, também conseguimos avaliar a pertinência do discurso historiográfico que abordou essa questão. Tal projeto historiográfico proposto por Michel de Certeau, que em sua extensiva análise sobre o discurso histórico concluiu que o desenvolvimento da historiografia contemporânea ocorre na medida em que é possível "testar os modelos explicativos" (CERTEAU. 1982, p. 114) que norteiam as análises sobre o passado, pode ser parcialmente realizado nessa pesquisa, visto que temos fontes históricas que permitem relacionar os grandes modelos historiográficos que analisaram a relação da C\&T com os projetos econômicos/sociais promovidos pelo regime militar e destes com a experiência individual de sujeitos que participaram desse contexto.

Propomos desenvolver essa tarefa de análise histórica nos próximos itens, quando abordaremos os depoimentos proferidos por alguns intelectuais/pesquisadores atuantes em Campinas, correlacionando a perspectiva individual do entrevistado com a historiografia que contempla tais temas. Esperamos que esses depoimentos também permitam aprofundar o entendimento de como diferentes sujeitos históricos reagem às circunstâncias conjunturais, se adaptando às demandas de sua época, ao mesmo tempo em que abrem espaços de realização de projetos e visões de mundo.

\subsection{A Política de C\&T Brasileira após o Golpe de 1964}

A historiografia que aborda as condições estruturais do apoio à pesquisa científica no Brasil após o início do regime militar $^{79}$ demonstra que nos anos imediatos à consolidação do sistema autoritário e conservador de poder não existia espaço para grandes investimentos no setor de C\&T. O governo Castello Branco voltou seus esforços para a implementação de uma política econômica restritiva, preocupada com a melhoria da arrecadação fiscal, redução de gastos governamentais e controle da inflação (SKIDMORE, 1988). Nessa perspectiva, o governo trabalhava em modestas iniciativas

\footnotetext{
79 Uma discussão aprofundada sobre tais questões pode ser verificada em: MOTOYAMA, S. 1999. Fapesp: Uma história da política científica e tecnológica; Idem. 2004. Prelúdio para uma História: Ciência e Tecnologia no Brasil; VARGAS, M. (Org.) 1994. História da Técnica e da Tecnologia no Brasil.
} 
para o campo da ciência e pesquisa, tais iniciativas eram voltadas principalmente à ampliação do acesso à educação e à racionalização do emprego dos equipamentos de C\&T e laboratórios de P\&D disponíveis (GUIMARÃES, 1985).

Fica implícito nessa primeira etapa da política de C\&T idealizada pelo regime militar que a incorporação de máquinas e equipamentos de alta tecnologia ocorreria apenas, ou principalmente, através do comércio com fontes externas (VARGAS, 1994). Dessa maneira, durante o período de 1964 a 1967, universidades e institutos de pesquisa brasileiros precisam se adaptar a uma conjuntura pouco favorável.

Nesse contexto enquadra-se o depoimento que será analisado a seguir. Em 1965, Rogério C. Cerqueira Leite retorna ao Brasil depois de passar um longo período trabalhando em instituições de pesquisa no exterior. No trecho transcrito abaixo, referente a um depoimento concedido ao CPDOC/FGV, em 1977, o intelectual descreve como encontrou a estrutura de apoio à $\mathrm{P} \& \mathrm{D}$ e $\mathrm{C} \& \mathrm{~T}$ no país:

Nos Estados Unidos, na Universidade, eu era tratado como cientista. Era mesmo. Se ia a uma Universidade dar uma conferência, o reitor ia me esperar, o vicereitor ia me buscar, me levavam para almoçar, jantar. Eu cheguei lá no ITA depois de todo esse auge, fui tratado como um garoto que voltou pra casa. $\mathrm{O}$ natural era isso mesmo. Não me davam bola nem nada, eu não conseguia nem falar com o chefe de departamento, quanto mais com o reitor. O ressentimento inicial foi grande. A minha vingança foi tentar montar um laboratório com a sucata de outro professor. Foi bom, mas o diabo é que não resolveu nada. $\mathrm{O}$ fato de saber que no Brasil ninguém dava importância, ninguém dava bola, ninguém dava bola para a pesquisa, a pesquisa era considerada um certo... Eu me lembro que fui conversar com o presidente do Conselho Nacional de Pesquisa, que era um cara decente, bacana, etc (...) O que me chocou, ele me recebeu, está certo, mas achava que era um favor que ele e o CNPq faziam e, claro que ele era um homem educado, evoluído, mas isso era uma atitude geral. Ele é que estava fazendo um favor pra mim em custear minhas pesquisas, ou ele, ou o CNPq, seja lá quem for. Quer dizer, eu estava certo de que vim para o Brasil fazer um favor para o Brasil, fazer pesquisas, desenvolver, ensinar os outros. Chego aqui e não, sou o pedinte, eu tenho que esmolar, eu é que tinha que pedir. Também se eu não quisesse, eu ia me acomodar na posição de professor, ninguém ia dar bola, não ia fazer a mínima diferença. (...) Eu era um indivíduo que ia lá, "Pelo amor de 
Deus, me dá um dinheirinho aí". Quer dizer, o dinheiro não veio de qualquer maneira. Havia boa intenção, um dia viria. Havia outras coisas mais importantes. Eu não achava, naquela época, que pudesse haver coisa mais importante que fazer física do Estado Sólido. Essas coisas me aborreciam profundamente, eu era sempre o pedinte. (...) Ainda hoje, quando vou pedir alguma coisa ao Pelúcio, estou pedindo a ele me fazer um favor. Apesar de ele ser um indivíduo mais alerta que a média brasileira, mas a atitude continua a mesma. Somos nós que pedimos. Quer dizer que é um favor que se faz ao pesquisador dar meios de fazer sua pesquisa, meio de ensinar, de formar gente, etc... (ROGÉRIO CEZAR DE CERQUEIRA LEITE, 19 Dez. 1977, p.44-46)

Conforme vimos no fragmento transcrito, é clara a insatisfação do cientista, que ao voltar para sua pátria, não encontra a estrutura de apoio à pesquisa científica esperada. Também percebemos como essa insatisfação causava tensões administrativas dentro da universidade na qual o pesquisador estava inserido.

A atitude de se montar um laboratório com "sucatas" alheias, além de uma resistência ao estado das coisas, também pode ser lida como uma provocação à estrutura de C\&T do país. Percebemos dois movimentos nesse processo. Por um lado o pesquisador conseguiu a satisfação de se mostrar como parte ativa na realização de seus anseios profissionais e pessoais. O outro lado da moeda dessa opção estava no inevitável desapontamento gerado pelo baixo engajamento a essa sua iniciativa individual. A conclusão retrospectiva do pesquisador aponta tal resultado, apesar dos esforços, o saldo dessa empreitada não foi positivo. Cerqueira Leite, em uma fala curta, informal, mas extremamente descritiva, apresenta o desfecho de suas ações ao afirmar "Foi bom, mas o diabo é que não resolveu nada".

Parte da frustração e mesmo a "rebeldia" profissional pode ser entendida como resultantes do percurso percorrido por Cerqueira Leite naquela conjuntura. Em 1965, o então pesquisador voltava ao Brasil depois de conhecer uma das melhores estruturas de P\&D do mundo. Cerqueira Leite tinha se doutorado em física de sólidos pela universidade de Paris (Sorbonne) no ano de 1962. A partir de então, se estabeleceu no Bell Laboratories, como pesquisador. Após esse período, retornou ao Brasil, mas sua permanência profissional em instituições de ensino e pesquisa se mostrou reduzida. A falta de receptividade nacional aos projetos de $\mathrm{P} \& \mathrm{D}$ provavelmente explica o rápido 
retorno do pesquisador à estrutura do Bell Laboratories, instituição da qual sairia para voltar ao Brasil apenas em 1970, momento onde o pesquisador foi convencido de que o regime militar havia transformado a estrutura de apoio à pesquisa no país abrindo espaços para iniciativas voltadas à $\mathrm{P} \& \mathrm{D}$.

Também percebemos nesse depoimento o desconcerto demonstrado pelo intelectual em relação ao modo como a academia científica brasileira se relacionava com o sistema de apoio à pesquisa do país. Nessa entrevista, concedida em 1977, é exemplar a maneira como Cerqueira Leite demonstra em suas colocações o ambiente de questionamentos e críticas que começava a surgir no horizonte político brasileiro.

A partir de então, parte dos intelectuais e pesquisadores passam a reagir de maneira aberta às iniciativas mal sucedidas do governo, que não conseguia colocar em prática soluções que resolvessem os problemas estruturais que afetavam a economia brasileira abalada pela crise do petróleo.

Se no final dos anos 70, o regime militar procurava priorizar investimentos aos setores da indústria eletrônica, bens de capital, química, petroquímica, siderúrgica, metalúrgica e aeronáutica. Por outro lado, via tais iniciativas não progredirem, principalmente devido à dificuldade de encontrar maneiras de transformar substancialmente essa estrutura produtiva, principalmente no sentido de garantir $o$ controle do capital nacional no processo de modernização em curso e modificar os padrões de financiamento e as dinâmicas de acumulação (GUIMARÃES, 1985).

O depoimento de Cerqueira Leite enquadra-se nesse contexto, onde a discordância com as ações do regime militar ganham tons cada vez mais fortes e definidos. Inclusive, no mesmo ano em que a entrevista foi realizada (1977), nossa pesquisa identificou a participação desse pesquisador em uma conferência sobre o estado da C\&T do país na conjuntura de crise. O encontro, nomeado como Seminário de Ciência, Tecnologia e Estratégia Para a Independência, ocorreu na Unicamp e teve a participação de Carlos Lessa, Miguel Wlonczek, Maria Conceição Tavares, e outros. 
Como resultado do debate e das discussões realizadas, percebemos conteúdos altamente questionadores aos rumos que estavam sendo tomados pelo governo instituído ${ }^{80}$.

Nesse momento de crise, Cerqueira Leite claramente advogava a necessidade de uma estrutura de apoio mais efetiva às demandas da C\&T. Conforme já discutimos nessa dissertação, na visão desse intelectual, o pacto que a universidade fez com o poder para usufruir da estrutura desenvolvimentista fragilizava a posição das instituições de ensino e pesquisa em uma conjuntura de crise e consequente desmonte de tal estrutura ${ }^{81}$. Essa conclusão, emitida em entrevista à imprensa em 1979, pode ser resgatada no depoimento concedido ao CPDOC transcrito acima.

Percebemos que a narrativa escolhida pelo intelectual, que acentua o caráter precário da atuação profissional do pesquisador, parte de uma condição existente no passado, ou seja, no início do regime militar, para descrever uma situação que ainda não tinha se resolvido. Na visão de Cerqueira Leite, mesmo sujeitos ilustrados, como José Pelúcio, ainda demonstravam com suas ações o caráter insuficiente das iniciativas de apoio a P\&D e C\&T. Fica evidente no depoimento um incômodo com a posição subserviente que os pesquisadores precisavam manter em sua relação com os órgãos de apoio a pesquisa. Constatamos também que esse desconforto tinha origens antigas, datadas pelo menos desde o ingresso mal sucedido no ITA, em 1965.

Concluímos que o desenvolvimento de uma situação de crise estrutural do regime militar abriu espaços a questionamentos há muito sufocados. Fato já observado pela historiografia de história da ciência que analisa esse período (MOTOYAMA, 2004).

Para além da política econômica e suas relações com a organização de um sistema de apoio à C\&T e $\mathrm{P} \& \mathrm{D}$, a instalação do regime militar trouxe como um dos seus resultados a instalação de um amplo aparelho repressivo voltado ao controle e eliminação de potenciais opositores ao regime.

\footnotetext{
${ }^{80}$ Estado de S. Paulo, 13 dez. 1977.

${ }^{81}$ Folha de S. Paulo, 20 set. 1979.
} 
A historiografia que analisa a atuação das forças repressivas durante a ditadura militar é extensa ${ }^{82}$, entretanto é ponto comum na análise dessas obras que o período pós o A.I 5 corresponde ao momento de maior violência e intolerância do Estado com indivíduos ou instituições classificadas como portadoras de ameaças à segurança nacional. O ufanismo ideológico propagado pelo governo Geisel (1969-1974), e a defesa da unidade nacional sintetizada no lema "Brasil, ame-o ou deixe-o", marcam ideologicamente esse período.

Saul Gonçalves d'Ávila comenta como os pesquisadores na Coppe (Instituto Alberto Luiz Coimbra de Pós-Graduação e Pesquisa de Engenharia) vivenciaram essa atmosfera nos anos de 1968 e 1969. Também descreve a postura dos intelectuais dessa instituição quanto aos rumos políticos do país nessa conjuntura:

Vou te dizer o seguinte, a totalidade da turma que estava na COPPE, quase noventa e nove por cento dessas pessoas simplesmente ignoravamo que estava acontecendo. Nós estávamos preocupados em construir o país. Ignorávamos o ambiente político porque acreditávamos estar mudando as coisas do nosso jeito. A nossa maneira de mudar era construir, não destruir a estrutura que estava lá.

Existia um clima, sabíamos que não era possível fazer qualquer coisa, batia sim um certo medo. Mas não era terror. Se você pegar o Pasquim, jornal da época, todo mundo ridicularizava os militares. Chamando de gorilas, aquele negócio todo. O Stanislaw Ponte Preta estava publicando o famoso FEBEAPÁ, o Festival de Besteiras que Assola o País. Porque se a Dilma fala bobagem, os milicos falam também, pô. A turma tirava sarro mesmo e ninguém ia preso por isso. (...) Não havia interferência ideológica nenhuma.

O único momento que eu senti que havia algum controle de governo foi quando eu quis apresentar a minha primeira tese de mestrado, ou segunda, antes de ir para o pós-doutorado, já tinha umas cinco teses prontas, porque meu laboratório estava crescendo e fui usando os alunos que trabalharam na montagem do laboratório de termodinâmica. Mas senti um controle federal quando quis ir à Venezuela, que não é a Venezuela de hoje, quando quis ir apresentar meu trabalho em um congresso internacional de engenharia química. Eu nunca tinha saído do país antes e precisei sair. O meu passaporte, que era um passaporte

${ }^{82}$ Segue algumas obras de referência sobre a repressão durante o regime militar: ALVES, M. 2005. Estado e Oposição no Brasil (1964-1984); AQUINO, M. A. 1999. Censura, Imprensa, Estado Autoritário (1968-1978); FICO, C. 2001. Como Eles Agiam. Os Subterrâneos da Ditadura Militar: Espionageme Política; REZENDE, M. J 2000. A Ditadura Militar no Brasil: Repressão e Pretensão de Legitimidade (1964-1984). 
especial, por ser funcionário da universidade, era um passaporte azul, pois eu era vinculado ao governo. Para conseguir o visto de saída eu tive que ir à Brasília. Mandei o meu passaporte para o MEC e foi providenciado o visto.

Nunca tive nenhum problema com perseguição política ou interferências. Ao contrário, me deixaram trabalhar em paz, me deram dinheiro. As condições de pesquisa eram as melhores que você poderia esperar para o Brasil. Como no ITA deveria ser, e como na USP também.

\section{Pergunta}

Percebemos certa saudade de alguns pesquisadores quanto a essas condições.

\section{Saul Gonçalves d'Ávila}

Com certeza. Alguns chamam dos melhores anos de suas vidas. Não é meu caso, os melhores anos da minha vida foram sempre (rindo). Mas eu não tive esse problema.

Uma vez, para não dizer que nunca aconteceu nada, e nesse caso eu tive medo, percebi que algo estava errado desde o momento que entrei pra trabalhar. Meu trajeto para trabalhar todo dia era da Zona Sul até o Fundão. Depois eu fui morar na Ilha do Governador. Vinha com um ônibus da COPPE, porque não tinha carro na época. Então estávamos entrando na Ilha do Fundão e tinha um destacamento da PM, não com toda essa parafernália de hoje, mas era uma tropa de choque estacionada. A gente logo suspeitou que alguma cois a tinha acontecido, pois a presença deles era ostensiva. Esse fato quebrou a paz do campus, a gente sabia que não tinha que fazer demonstrações, nem cois a nenhuma, mas existia algumas coisas de vez em quando. O dia seguiu normalmente até a hora do almoço, almoçava no restaurante universitário, nesse dia a polícia invadiu para pegar alguém, eu não lembro quem foi. Todo mundo saiu correndo para suas salas e eu também, meu laboratório ficava longe, uns quinhentos metros, mais ou menos. Ao chegar a COPPE fui avisado que a polícia estava atrás da gente, continuamos correndo, entramos no prédio, que tinha uma porta de vidro. O Coimbra estava na COPPE nesse dia, soube do que estava acontecendo e saiu para o lado de fora da porta. Chegou um tenente da PM querendo invadir pra pegar um sujeito de camisa vermelha que tinha ofendido o militar, depois a gente soube que era um funcionário. O Coimbra peitou os policiais, falou que ali era uma instituição de pesquisa, que eles não tinham o direito de estar ali e iriam causar uma crise internacional, pois ali existiam professores de todas as nacionalidades. Você sabe como é, um sujeito que está embalado com o cassetete na mão, não para pra ver quem é quem, apanha todo mundo. Esse foi um dos acontecimentos. 
Outra vez me disseram que a polícia estava dando uma batida no bloco A. A Coppe ficava no bloco $\mathrm{G}$, onde eu te descrevi, e o meu laboratório ficava no bloco A, a meio caminho entre a COPPE e o restaurante. Meu laboratório ficava no sexto andar, e o trabalho de três, quatro anos, estava naquela sala. Na hora eu pensei que iam entrar lá e quebrar tudo, corri para o laboratório e me fechei na sala. Fiquei esperando o que eles iam fazer. Mas eles não foram até lá e nem quebraram nada nos outros laboratórios. Eu que fiquei com medo.

Essas são passagens mostram fatos excepcionais. Tudo aquilo que eu pedi de bolsa, de projeto de pesquisa, depois os auxílios que eu tive quando voltei do pós-doutorado, tudo is so foi concedido. Nunca houve barganha, tudo foi feito por mérito, inclusive as promoções dentro da COPPE. Não havia aparelhamento, não existiam questionamentos ideológicos. Lá se convivia, discutíamos, falávamos a favor e contra o governo numa boa. Essa coisa que a turma fala de anos de chumbo, se houve, eu não vi. Não foi para nós. Até porque não existia razão nenhuma para isso. Nós estávamos em consonância com aquela visão maior de país, estávamos voltados para o desenvolvimento científico e tecnológico. Estávamos lá para construir, não estávamos para mudar o regime.

Obviamente, se me perguntar se eu gostava dos militares, é óbvio que não. Se me perguntar se eu gostaria de ter eleições, é óbvio que eu gostaria. Mas isso não estava nas prioridades. Lógico que mais tarde no governo Figueiredo, quando eu já estava de volta ao Brasil, esse negócio estava se estendendo demais (SAUL GONÇALVES D’Á VILA, 22 Jul. 2015, p. 16 a 19.).

Acreditamos que esse depoimento é fundamental para o entendimento da conduta de parte considerável dos cientistas e pesquisadores envolvidos com a C\&T durante o regime militar.

$\mathrm{Na}$ própria estrutura narrativa escolhida demonstra-se a grande contradição social existente na época, contradição essa que permeava todas as atividades, e que gerava, por sua existência, uma atmosfera de permanente incerteza e tensão.

Vemos esse processo no momento que Saul Gonçalvez d'Ávila reconhece a atmosfera de medo que circundava a sociedade. O entrevistado também expõe em sua fala o quanto dessa atmosfera era camuflada pelo evidente apoio que o Estado dava aos pesquisadores voltados as iniciativas de $\mathrm{P} \& \mathrm{D}$ em tecnologia. 
O medo circunstancial da violência desmedida da ação repressiva - já que "um sujeito que está embalado com um cassetete na mão não para pra ver quem é quem, apanha todo mundo" - não era o suficiente para um rompimento efetivo com as estruturas de poder, nesse contexto, esses indivíduos preferem se concentrar nos resultados benéficos prometidos pelo desenvolvimento científico e tecnológico.

Para parte dos pesquisadores envolvidos com a P\&D e C\&T durante o regime militar, responder as tensões cotidianas vivenciadas por uma sociedade marcada pelo signo do autoritarismo era fazer uma aposta consciente nos resultados positivos da construção de uma sociedade desenvolvida. Nesse sentido, esses intelectuais e cientistas buscavam responder as dúvidas do presente com a disposição individual fundamentada na força do trabalho construtivo. Dentro dessa perspectiva, nega-se a possibilidade de mudanças através da oposição e/ou críticas. Como diz D’Ávila em determinado ponto de seu depoimento "A nossa maneira de mudar era construir, não destruir a estrutura que estava lá".

Outra questão evidente no trecho transcrito é o grau de cuidado dispensado pelo regime militar às instituições de $\mathrm{P} \& \mathrm{D}$. Se a violência podia irromper em breves e episódicas quebras da rotina - mas de caráter marcante devido à vulnerabilidade experimentada nesses efêmeros embates - a média do cotidiano desse grupo de pesquisadores era a do espaço da liberdade de iniciativa e criação.

Inclusive o espaço do direito ao diálogo era experimentado dentro de alguns desses centros de pesquisa científica. Esses pesquisadores usufruíam do apoio afiançado pela associação realizada entre o campo da C\&T e o planejamento econômico do governo. Essa relação de interdependência, além de proporcionar subvenção aos projetos de $\mathrm{P} \& \mathrm{D}$, também garantia uma relativa autonomia a alguns espaços universitários. A atitude do professor Alberto Luiz Coimbra de desafiar a tropa de choque da polícia seria duramente penalizada caso esse intelectual estivesse em qualquer outro grupo marcado pelo estigma da intolerância política e repressão policial. A cautela assumida pelas forças repressivas nesse episódio ilustra como o governo estava ciente da importância de preservar uma relativa liberdade a alguns espaços 
especiais, algumas instituições de P\&D estavam contempladas por essa salvaguarda, a COPPE era um desses lugares.

\subsection{O Modelo Brasileiro de Desenvolvimento Incorpora a Ciência e}

\section{Tecnologia}

Conforme já analisamos extensivamente nessa dissertação, a partir do governo Costa e Silva, o regime militar passou a incorporar em seu planejamento econômico consideráveis investimentos ao campo da C\&T. A historiografia que avalia esse processo considera que a partir da elaboração do Programa Estratégico de Desenvolvimento (PED), em 1968 , o Estado brasileiro sistematicamente abriu espaços de sustentação para a P\&D. Por trás dessa iniciativa estava o entendimento de que existiam setores estratégicos da economia que poderiam se beneficiar de uma relação mais próxima com a C\&T (GUIMARÃES, 1985).

O reitor Zeferino Vaz, em depoimento dado ao CPDOC/FGV, descreve como aproveitou essa conjuntura para conseguir abrir linhas de financiamento para pesquisa:

Isso foi em 1967, 1968 e essa gente veio falar comigo, e eu disse: "Olha aqui, minha gente, o projeto é esse. Quando vocês vierem, vocês não terão sequer mesa para sentar, não tenho nada para oferecer, mas eu garanto que quando vocês estiverem aqui eu vou conseguir dinheiro”. E foi assim. (...) Quando chegaram aqui, eu fui ao Dilson Funaro, que era o Secretário de Planejamento, grande empresário - é o presidente da Trol, essa empresa de plásticos - ele era o Secretário de Planejamento, engenheiro, inteligente como o diabo e eu disse: "Dilson, olha aqui, está vendo essa gente? Olha o currículo deles! Olha o passado! Olha os projetos! Essa gente não tem nada, não tem mesa, não tem cadeira, não tem edifício, não tem nada. Eu preciso de dinheiro. Me dá dinheiro aí." Eu devo dizer-lhes que nunca o governo me negou dinheiro. Ele me deu logo 5 milhões, de cara. Naquela época era um bocado de dinheiro - isso equivale hoje a 20 milhões ou 30 milhões de cruzeiros - para começar a comprar equipamentos e conseguir edifícios. Logo depois, eles me colocaram em contato com o Marcos Viana, do BNDE, e o Pelúcio Ferreira, da Finep. (...) Mas estava demorando, aquele negócio não saia. Um dia veio o Rogério desanimado. (...) Mas eu tinha um trunfo muito grande, que era o Ministro da Fazenda, o Delfim 
Netto. O Delfim Netto é um talento matemático, grande matemático, aplicado a Econometria e muito amigo meu... (...) Fui ao Delfim, pedi uma entrevista a ele, e disse: "Delfim, olha, está acontecendo isto: Nós pedimos lá para o Pelúcio, mas o Pelúcio está encontrando dificuldade. O Marcos Viana está fazendo não sei o quê.” Hoje o Marcos Viana é amicíssimo meu. Esteve lá, comigo, agora, em Ribeirão, nesse último seminário, onde ele fez uma palestra brilhante. -“Como é essa história, Delfim? Você é quem dá o dinheiro." - Ele disse: "Ele está negando dinheiro? Pega esse telefone que eu vou falar com ele. Ô, Marcos Viana, está aqui o seu mestre e patrão. - Quem é? - É o Zeferino Vaz. Você prometeu a ele 5 milhões. Ou você dá o dinheiro pra ele ou muda de país. Porque eu devo obrigações e você tem que dar esse dinheiro para ele. Eu sei que ele sabe aplicar bem." E, realmente, saíram os 5 milhões. Mas depois as portas se abriram, e então a Finep, depois a Secretaria de Tecnologia Industrial, quando começamos a desenvolver os planos de desenvolvimento tecnológico. (ZEFERINO VAZ, 12 Jan. 1977 e 13 Jan. 1977, p. 137 a 140)

Conseguimos identificar no discurso do reitor e fundador da Unicamp elementos que nos permitem aprofundar a reflexão sobre como a estrutura de apoio a P\&D e C\&T estava sendo constituída. A historiografia que analisa esse processo procura demonstrar que as ações do Ministério da Fazenda eram marcadas por um viés pragmático na gestão dos investimentos para a C\&T. Conforme essa análise, o excesso de pragmatismo na gestão dos investimentos era um fator limitador das ações desse ministério (GUIMARÃES, 1985).

Recuperando os fatos ocorridos na Unicamp pela perspectiva do reitor Zeferino Vaz, vemos que o processo de investimento na construção de laboratórios e desenvolvimento de projetos teve início em grande medida graças às relações pessoais cultivadas pelo gestor da universidade. Particularmente nesse caso, a demora de repasse de recursos tinha origem no Secretaria de Planejamento do Estado de São Paulo. Zeferino Vaz utilizou-se da proximidade com o ministro Delfim Netto e conseguiu agilizar a abertura da linha de financiamento para os projetos da universidade.

A partir das informações disponíveis no depoimento de Zeferino Vaz, temos dados para propor que a estrutura de financiamento a $P \& D$, e a participação dos diversos ministérios federais e estaduais no sistema de apoio a C\&T, era marcada por 
um padrão de interação, no qual elementos externos ao planejamento poderiam influir decisivamente no andamento de projetos.

Dentro dessa interação entre os elementos participantes da estrutura de C\&T e $\mathrm{P} \& \mathrm{D}$, a especificidade histórica das instituições e os relacionamentos entre os diferentes gestores podiam proporcionar novos arranjos e possibilidades de investimento. Em Campinas, o ministério da Fazenda não se abstém de intervir a favor dos investimentos para a Unicamp. Nesse caso, a postura conservadora e pragmática assumida pelo ministério da Fazenda foi contornada pela boa relação que o reitor da universidade mantinha com a cúpula do regime militar.

O reitor Zeferino Vaz explicita em seu depoimento que, a partir do momento que o Ministério da Fazenda viabilizou os primeiros investimentos para a construção dos laboratórios solicitados pelos professores contratados, outras instituições de apoio à pesquisa passaram a financiar de maneira mais estruturada as iniciativas da Unicamp.

Além da elaboração de uma política específica para a C\&T, o regime militar também procurou garantir que os espaços de P\&D do país fossem ocupados por indivíduos competentes e dispostos a desenvolver a estrutura de pesquisa do país. Dentro dessa iniciativa se enquadra o movimento de retorno de intelectuais que se encontravam radicados no exterior (SKIDMORE, 1988).

Rogério C. Cerqueira Leite descreve os esforços patrocinados pelo regime militar em "repatriar" os pesquisadores brasileiros que estavam em países estrangeiros, e o apoio fornecido às atividades de C\&T pelo regime militar a partir da década de 1970:

Eu me lembro que recebi várias visitas de embaixadores, que nos Estados Unidos fizeram reuniões para vir procurar brasileiros que tinham saído por causa da Revolução, o que não era o meu caso, pois não saí por causa da Revolução, saí do Brasil antes. Mas procuraram os brasileiros para falar que as coisas estavam melhores, etc e tal. Lembro também que o Senado teve uma iniciativa, o Senador Arnon de Melo, pai do Fernando Collor de Melo, esteve lá no Bell Laboratories por duas ou três vezes para conversar conosco, comigo e com o Sérgio Porto principalmente. Ele não chegou a visitar o Bell, mas nos encontramos na região 
algumas vezes e ele realmente estava decidido a trazer os brasileiros, como incumbência do Senado.

Pergunta:

Dentro da Universidade, o governo militar nessa época está reformando todo o Ensino Superior, inclusive está disponibilizando verbas para pesquis a na área de Engenharia e mesmo para a P\&D...

Professor Rogério Cezar de Cerqueira Leite:

Quando eu vim pela primeira vez eu não consegui verba nenhuma, não havia chance. Isso foi em 65, logo depois do golpe. Quando eu cheguei em 70 havia uma disponibilidade no BNDES. Quando eu cheguei já havia verba assegurada pelo CNPQ e pela FAPESP, as duas instituições foram muito generosas, pagaram minha viagem, fizeram o diabo. Deram dinheiro o suficiente para montar pelo menos três laboratórios independentes. Mas como eu, que não sou muito modesto, fui atrás de dinheiro do BNDES e no BNDES estava o Pelúcio Ferreira, que foi uma pessoa extremamente importante para o desenvolvimento da Ciência e Tecnologia no Brasil. Ele imediatamente aceitou o projeto que eu tinha para a Unicamp, que era um projeto na área de semicondutores, mas que envolvia desde a produção de semicondutores até a produção inclusive de dispositivos. Então eu fiz um projeto grande, e quando o Pelúcio saiu do BNDES e foi para a Finep, e a Finep começou a crescer e ter bastante dinheiro, também conseguimos apoio. Além disso, eu tinha apoio do Ministro do Planejamento, João Paulo dos Reis Velloso, e a Finep recebeu muito dinheiro.

Para você ter uma ideia, o Instituto de Física conseguiu, durante o período em que estava como Diretor do Instituto de Física, até recursos externos, como o do BID, por exemplo. Recursos no montante de até três vezes o valor do orçamento da Universidade, tudo is so só para equipar o Instituto de Física. Mas foi durante um momento de investimento, de criação de laboratórios. (ROGÉRIO CEZAR DE CERQUEIRA LEITE, 02 Jul. 2015, p. 5 a 7)

Em seu depoimento, Cerqueira Leite nos transmite como vivenciou a influência do Estado brasileiro nos anos finais da década de 60. Percebemos que o movimento da atração aos cientistas e pesquisadores no exterior perpassou diversas instituições governamentais, tanto na esfera federal, quanto na estadual. Para esse objetivo mobilizaram-se membros do Senado e instituições de apoio a pesquisa, como Fapesp e CNPq. 
Também percebemos o lugar privilegiado da pesquisa em tecnologia, vide o vulto dos investimentos realizados para a estruturação do Instituto de Física da Unicamp. Com uma narrativa fundamentalmente descritiva, Cerqueira Leite nos permite comprovar boa parte das hipóteses aventadas pelas análises históricas sobre esse momento. Quando a historiografia define o governo Costa e Silva como o período de transição no status da C\&T dentro do planejamento de governo, verificamos nessa entrevista que para a Unicamp tal afirmação não é um exagero retórico. O depoimento de Cerqueira Leite ilustra como boa parte dos cientistas e pesquisadores envolvidos com a P\&D dentro dessa universidade receberam um grande amparo para suas iniciativas a partir do final da década de 1960.

Ainda sobre essa questão, José Ellis Ripper comenta em seu depoimento a coincidência positiva entre o momento de surgimento de inovações em laboratórios que potencialmente revolucionariam as telecomunicações e a conjuntura positiva no ambiente político brasileiro, conforme encontrou ao ser contratado pela Unicamp:

Quando vim para Física, por coincidência, em nível de laboratório, duas descobertas surgiram. A primeira era um laser semicondutor que conseguiu superar continuamente a temperatura ambiente, descoberta essa que foi feita onde eu trabalhava, a Bell. A outra foi o anúncio da Corning Glass do desenvolvimento da primeira fibra ótica com atenuação da ordem de $20 \mathrm{~dB}$ por quilômetro, chamaram-na de Guia de Fibra Ótica. Isso para quem trabalhava no campo tornava a comunicação ótica praticamente irreversível. Por outro lado, a gente está acostumado a achar que o progresso tecnológico é muito rápido, mas não é. Colocando o progresso tecnológico em preto e branco, desconsiderando os matizes cinzentos do processo, ou o progresso tecnológico acontece em uma evolução, aos poucos você vai criando incrementos, ou você tem uma quebra tecnológica. Quando ele ocorre por uma evolução, as empres as que controlam o mercado tendem a controlar cada vez mais. (...) Por outro lado, quando você tem uma quebra tecnológica, muitas das vezes em nível de laboratório is so é feito nas grandes empresas, mas isso ameaça o mercado dessas grandes empresas. Normalmente o processo termina com a criação de novas empresas que começam do zero. Na parte de componentes, por exemplo, isso aconteceu. Você primeiro teve a invenção do transistor, depois do circuito integrado, depois circuitos de alta integração e em cada uma dessas quebras o mercado mudou completamente. Analisando quando você tem essa quebra, entre você demonstrar 
a viabilidade em laboratório e aquilo virar economicamente importante, em geral leva na ordem de quinze anos. Então quando eu vim ao Brasil comecei a defender que essa era uma área que a gente deveria entrar, pois apenas em quinze anos essa área seria explorada economicamente, teríamos tempo para formar gente. De fato isso aconteceu. Terminamos criando um polo industrial nessa área.

Pergunta:

Lendo jornais dos anos 70 percebemos que jornais, como o Estado de São Paulo, chegaram a dar uma página inteira para o senhor falar dessa questão.

Profes sor José Ellis Ripper:

É justamente nessa época que eu voltei. Eo assunto da fuga de cérebros tinha se tornado politicamente incômodo. O governo militar inclusive realizou uma reunião em Washington, pegou todo esse pessoal que estava fazendo pesquisa nos Estados Unidos e ofereceu mundos e fundos. Então claramente a nossa volta virou notícia de jornal, pois o governo estava conseguindo trazer esse pessoal de volta. E eu tinha essa ideia, estava convencido que a gente tinha tempo para desenvolver essa tecnologia. De fato is so aconteceu. Tambémé interessante para esse processo a criação da Telebrás.

Pergunta:

Lembrando que o momento econômico era muito propício. Estava-se vivendo o milagre. Como o senhor percebeu a disponibilidade de investimentos?

Profes sor José Ellis Ripper:

Basicamente a gente voltou ao Brasil com a promessa de grandes investimentos para a pesquisa. Desde a época dessa reunião em Washington. Soma-se o fato de que a Unicamp era uma universidade nova e o Zeferino era um excelente marqueteiro (JOSÉ ELLIS RIPPER, 28 Jul. 2015, p. 6 e 7.).

Para contextualizarmos a descrição do professor Ripper sobre as possibilidades presentes no início da década de 1970, precisamos recuperar a análise do I PND efetuada por Guimarães (GUIMARÃES, 1985). Ao abordar os planos do regime militar para a C\&T nos primeiros anos da década de 70, o historiador demonstra que o apoio ao desenvolvimento tecnológico concentrar-se-ia em algumas áreas prioritárias - energia 
nuclear, pesquisa espacial, oceanografia, indústrias intensivas em tecnologia, tecnologia de infraestrutura e pesquisa agrícola - dentro desse planejamento buscava-se também agilizar o processo de transferência tecnológica e integrar a pesquisa universitária com a indústria em busca da inovação.

Nessa perspectiva, o grande acerto do trabalho liderado pelo professor Ripper estava na capacidade de integração de seu projeto com os objetivos do planejamento estratégico do governo.

$\mathrm{Na}$ entrevista percebemos que a escolha por desenvolver pesquisas em comunicação ótica e semicondutores ocorreu devido a considerações sobre alguns fatores estruturais existentes naquela conjuntura. Foi levado em conta o momento tecnológico, que permitia o desenvolvimento de pesquisas competitivas no cenário internacional, e o contexto favorável dentro do sistema de apoio a C\&T, pois o desenvolvimento tecnológico projetado realizaria alguns dos objetivos colocados pelo Estado na elaboração de suas metas desenvolvimentistas. Tais alicerces permitiram o bom andamento dos trabalhos do Laboratório de Pesquisas em Dispositivos, liderados pela atuação do professor Ripper.

Dessa maneira, percebemos que a sintonia entre as possibilidades tecnológicas e a disponibilidade de uma estrutura de apoio a P\&D foram os grandes elementos mobilizados no desenvolvimento de um setor tecnológico que se sobressaiu na estrutura do Polo de Campinas, a telecomunicações.

\subsection{Campinas como Polo Tecnológico}

Uma das principais questões abordadas nas análises sobre os resultados do polo tecnológico de Campinas nos anos 90 está na avaliação de como o avanço das políticas neoliberais desarticularam os projetos que durante a década de 1980 permitiram o crescimento dessa unidade tecnoprodutiva; também entram nessas análises considerações sobre a falta de efetividade das iniciativas locais que surgem no sentido de aprimorar a relação entre as instituições de pesquisa e o setor produtivo (JOIA, 2000). 
Tais assuntos foram abordados nos depoimentos de história oral com intelectuais que participaram da construção desse polo tecnológico. Analisaremos a seguir duas entrevistas que abordaram essas questões.

Rogério Cezar de Cerqueira Leite comenta como a dificuldade de interação entre a Ciatec, CPQD e Universidade de Campinas, e outras instituições de P\&D da região, dificultou o estabelecimento de um polo tecnológico vigoroso em Campinas:

A Ciatec foi criada, mas um novo prefeito removeu essa legislação, o Chico Amaral. Acho que só por volta de 1980 esse projeto realmente teve início. Eu fiquei como presidente da Ciatec, a despeito de não estar funcionando, porque todos os prefeitos que sucederam o Magalhães Teixeira sempre foram contrários, já que dá mais dinheiro se submeter aos interesses da especulação. Então eu tenho a impressão que a Ciatec teve uma sobrevida de uns vinte anos. Depois foi entregue a um malabarista do grupo do José Dirceu, não vou lembrar o nome dele, mas que era submisso ao José Dirceu e conseguiu vender uma parte do terreno para o Santander. Isso tudo foi rupturas.

Hoje a Ciatec já não é mais tão promissora quanto foi. Ainda existe espaço lá, o preço dos terrenos é muito caro, pois são especulações individuais. A Unicamp comprou uma parte dessa área para se expandir. Isso devia ter sido organizado pela própria prefeitura e a Ciatec. Mas não ocorreu, o acordo foi feito através de um entendimento direto que a universidade fez com o proprietário. Mas ela está lá, tem muitos terrenos para pequenas e médias empresas, mas não há interesse por causa dos custos.

Pergunta:

Voltando para os anos 70. Aqui tem o CPQD que na pesquisa em telecomunicações deu uma força para a cidade...

Professor Rogério Cezar de Cerqueira Leite:

É. Mas eles se desviaram. Hoje são quase intermediários. Hoje é uma pensão (comentário em tom de brincadeira/ironia). Alugam o prédio para outras pessoas. Mas no CPQD em si, fazem poucas coisas. Não existe mais a pretensão que existia de realizarem projetos de grande porte, como, por exemplo, fibras óticas. Isso acabou.

Pergunta: 
Enquanto existia um ambiente e condições favoráveis, dava pra sentir o impacto dessas demandas na economia?

Professor Rogério Cezar de Cerqueira Leite:

Eu acho que não.

Pergunta:

O impacto foi muito local, setorizado?

Professor Rogério Cezar de Cerqueira Leite:

Sim. Acho que não ajudou muito não. Veja, bem no começo trouxe um certo estímulo. Até por existir uma proximidade com a Unicamp. Hoje em dia elas não podem nem se comunicar, muito menos fisicamente. Havia uma estrada que ligava a Ciatec à universidade, mas essa estrada foi fechada por ordem da Unicamp. Um absurdo completo. Hoje o parque tecnológico está isolado da Unicamp porque fecharam os meios de comunicação, inclusive físicos. É claro que todo prefeito diz que vai abrir uma estrada, mas essa negociação é quase eterna. Há muitos anos que estão negociando uma estrada maior, só que nem a prefeitura, nem a universidade, consideram is so uma prioridade.

Pergunta:

O senhor acha que talvez faltou, entre outras cois as, entender o que estava sendo construído aqui?

Professor Rogério Cezar de Cerqueira Leite:

É, porque São Carlos e São José dos Campos são muito mais polos tecnológicos que Campinas. Aqui em Campinas existem algumas pessoas que falam que produzem nessa área, mas elas não fazem pesquisa. São multinacionais que trazem tudo pronto da Coréia, ou do Japão e dos Estados Unidos. Mas, realmente fazer pesquisa, em Campinas não existe empresa que faça e designe isso aqui como um polo tecnológico real. Muito mais sério é São José dos Campos e São Carlos e outros que estão surgindo por aí (ROGÉRIO CEZAR DE CERQUEIRA LEITE, 02 Jul. 2015, p. 11 a 13).

Comparado com toda a bibliografia que analisa o desenvolvimento do polo de Campinas, veremos que depoimento de um dos principais responsáveis pela formação 
dessa unidade tecnoprodutiva é um dos mais críticos em relação aos resultados e condições atuais.

Conforme vimos, em sua análise, Cerqueira Leite expôs parte dos resultados das pesquisas sobre a estrutura do polo tecnológico em Campinas. Para esse intelectual, a falta de interação efetiva entre a universidade e as empresas de tecnologia instaladas na cidade foi um ponto determinante na limitação dos resultados obtidos. Interessante observar que, o próprio isolamento físico da universidade em relação ao parque tecnológico é considerado como um indício da desagregação entre as demandas universitárias e os projetos industriais em curso.

Também vemos que a situação de desarticulação de um dos principais centros de pesquisa da cidade, o $\mathrm{CPqD}$, trouxe consequências danosas ao andamento dos trabalhos de P\&D realizados pelas empresas de tecnologia e telecomunicações. Nesse ponto, Cerqueira Leite reconhece que o desmonte da estrutura construída nas décadas de 70 e 80 foi determinante para limitar as empresas de tecnologia locais como simples montadoras dos projetos tecnológicos desenvolvidos nos grandes centros de P\&D do mundo. Nesse quesito o entrevistado entende que outros polos tecnológicos brasileiros conseguiram um sucesso muito mais significativo. Observamos que tais resultados são compartilhados na perspectiva de diversos trabalhos acadêmicos que se voltaram a analisar as condições do polo de Campinas (Conforme as análises de JOIA, 2000; DE MATTOS, 1990; GOMES, 1998).

Um ponto que foge das pesquisas sobre os resultados desse polo tecnológico está na negação de uma contribuição econômica efetiva dessa unidade tecnoprodutiva.

Para Cerqueira Leite, as repercussões iniciais podem ser qualificadas no máximo como geradoras de "um certo estímulo" para as relações econômicas do país. Entretanto, conforme vimos na análise de Paulo Joia, o Polo de Campinas proporcionou o desenvolvimento de tecnologia nacional para a fabricação de mais de uma centena de produtos (JOIA, 2000), resultado esse que podemos qualificar como significativo.

Entretanto é preciso situar as razões por trás da negatividade na hora de se avaliar os resultados desse polo. A perspectiva desfavorável é compreensível na medida 
em que verificamos que Cerqueira Leite esteve envolvido no nascimento desse projeto. Podemos especular que ao ver os descaminhos sofridos durante o andamento dos trabalhos de construção do polo o entrevistado não reconhece suas pretensões iniciais materializadas na estrutura constituída. Nossa pesquisa demonstrou no Capítulo 2 dessa dissertação que o grupo liderado por Cerqueira Leite partia de uma visão muito menos ligada às demandas especulativas e imobiliárias.

Além disso, soma-se as mudanças históricas vivenciadas na passagem dos anos 80 para a década de 1990, os impactos das transformações políticas também são determinantes nessa questão, e conforme já analisamos tais transformações não podiam ser contidas pelo ato de vontade de uma pessoa ou instituição. A estrutura política e econômica do país se transformou profundamente, junto a isso iniciativas locais sofreram inevitavelmente tal influxo histórico marcado principalmente pelo avanço do modelo neoliberal.

Ainda sobre esse tema, Saul Gonçalves D’Ávila comenta o processo de desestruturação das iniciativas promovidas pela Ciatec e Codetec:

Quando a Termoquip saiu da Codetec, eu disse que devia sair junto. Apenas lembrando que a Codetec foi acionista da Termoquip, possuíam dois por cento da empresa, e nós pagamos os royalties direitinho. Com a nossa saída a Codetec se esvaziou, mas essa era a ideia. Por exemplo, o coletor solar, era o produto que rendia dinheiro, no momento que a empresa saiu o que a Codetec recebia era o valor da licença, mas não dá pra viver só disso. E o funcionamento era exatamente esse. As equipes técnicas ficavam na Codetec enquanto existia um produto para se desenvolver. Essa era a ideia da incubadora.

Depois que saímos deixamos dinheiro em caixa, tudo direitinho. O Rogério nessa época vendeu um outro grande projeto de desenvolvimento de fármacos. Porque o Instituto de Química tinha um projeto de desenvolvimento de fármacos e o Brasil naquela época começou a investir em química fina. Mas esse projeto não era desenvolvido pelo nosso pessoal, era do Instituto de Química. O Jerez saiu da Rhodia e veio desenvolver esse projeto com o pessoal do Instituto de Química, eu não estava nesse meio.

Começaram a desenvolver fármacos com financiamento do governo. Compraram um prédio perto da Unicamp, prédio que ainda existe, a Codetec está sediada lá hoje. Nesse prédio construíram usinas piloto onde começaram a desenvolver os 
fármacos. Is so começou a mexer em outros interesses, porque eles começaram a quebrar patentes. Esses detalhes o Rogério pode esclarecer melhor, eu não conheço bem, mas parece que houve grande oposição.

Pergunta

O professor Rogério chegou a explicar um pouco do processo e pelo que contou a oposição acontecia até fora do país.

\section{Saul Gonçalves d'Ávila}

Exatamente, houve implicações políticas nessa história. Até ai tudo bem, sabíamos disso, era pra brigar mesmo. Mas nesse meio tempo infelizmente o Jerez pegou um câncer, o processo foi muito rápido e ele morreu. Ele era o cérebro do negócio. Nessa, a Codetec praticamente fechou porque as implicações políticas acabaram fechando a linha de financiamento.

Nesse processo, a Codetec terminou sendo desativada e vendida. Existe uma briga em torno desse assunto, inclusive tramitando na justiça, mas sobre esse as sunto o Rogério pode explicar melhor.

Pergunta

O senhor concorda que talvez esse fim melancólico da Codetec está ligado às mudanças pelas quais o país passou?

\section{Saul Gonçalves d'Ávila}

Não existe mais aquele clima. O país se desenvolveu, o assunto sobre inovação está aí, as universidades, hoje em dia, possuem incubadoras, já existe capital de risco. Naquela época não existia capital de risco.

Pra você entender um pouco mais minha participação. Depois dessa aventura em 1984, fui convidado para participar do governo Montoro e presidi a PROMOCET, a Companhia de Promoção Científica e Tecnológica do Estado de São Paulo, que hoje em dia já não existe mais. Pegando a experiência da Codetec a ideia era espalhar a ideia das incubadoras no Estado. Nós montamos uma incubadora em São Carlos que ainda existe. Essa empresa de São Carlos deu origem a mais de sessenta empresas até agora. Mas a ideia vem de antes. Como dizem, tudo começa com uma ideia, depois as coisas vão longe, não acabam. Hoje você está resgatando um pouco disso.

Pergunta 
Tentamos pelo menos identificar essas raízes. Esse é um processo bastante complexo.

Saul Gonçalves d'Ávila

Com certeza. O Rogério também pode dizer sobre a Ciatec, ele é o pai da ideia da Ciatec.

Pergunta

Mas parece que hoje em dia ele não vê a Ciatec caminhando para o que ele imaginava.

Saul Gonçalves d'Ávila

Lógico que não, esse é um outro momento. Se você olhar o setor público brasileiro vai perceber que ele não se conscientizou sobre a importância da tecnologia. Além disso, tudo se politizou demais, se perdeu a vis ão estratégica. $O$ pessoal se preocupa, demagogicamente, no meu entender, com o dito social. Pra mim o social é tudo, inclusive tecnologia. Mas qual é o papel da tecnologia no social? A tecnologia pra dar fruto demora dez, vinte anos. Enquanto ao fazer um programa de distribuição de benesses você recebe os frutos na próxima eleição. Em síntese é isso que está acontecendo no Brasil. Não existe uma visão estratégica de longo prazo, estamos vivendo para próxima eleição. Isso não traz consequência nenhuma. Você começa um programa que não termina. Às vezes o programa até é bom, merecia continuar, mas você distorce o programa, pois foi feito pelo outro. Um bom exemplo são os programas na área educacional, esses programas estão todos desarticulados. Não estou entran do nem em mais detalhes políticos para não contaminar o nosso discurso (SAUL GONÇALVES D’ÁVILA, 22 Jul. 2015, p. 36 a 38).

Duas questões se sobressaem na análise de D’Ávila sobre o resultado das iniciativas promovidas pela Ciatec e Codetec.

Em primeiro lugar vemos a alusão a cojuntura desfavorável vivenciada na década de 1990. Esse assunto, que já mapeamos em outras entrevistas, e que é pertinente a pesquisa acadêmica sobre o polo tecnológico de Campinas, é resgatado no depoimento de D'Ávila. Conforme a análise realizada pelo entrevistado, o avanço do projeto neoliberal e a fatalidade da morte do principal químico responsável pelo projeto de produção de fármacos colocou fim as principais iniciativas de colaboração entre a Codetec e Unicamp. 
O segundo ponto a ser ressaltado, e talvez o elemento mais importante dessa análise, está na relação que o professor D'Ávila entende existir entre o fracasso das iniciativas da Ciatec com o andamento das políticas de C\&T contemporâneas. Como é nítido nas ideias expostas pela entrevista, existe uma crítica endereçada às políticas sociais e tecnológicas realizadas nas últimas décadas. Entende-se que razões políticas e eleitoreiras solaparam projetos que exigiam investimentos constantes por uma longa extensão de tempo.

Essa perspectiva de alguma forma se adéqua a biografia de um pesquisador que vivenciou um período de estabilidade de investimentos para a C\&T. Inclusive conseguimos em um depoimento anterior perceber certo grau de saudosismo desse sistema de amparo à pesquisa que foi criado e desestruturado ainda durante o regime militar. A constatação de que os governos democráticos subsequentes não conseguiram manter a visão estratégica em ciência e tecnologia determina $o$ andamento dessa avaliação pessoal.

Podemos observar que a relação entre os resultados apresentados a partir da década de 1990 e as condições atuais é comum tanto ao depoimento de Cerqueira Leite, quanto à entrevista com D’Ávila.

A divergência entre as duas visões está no local onde a análise é colocada. Cerqueira Leite concentra sua crítica nas relações locais do polo tecnológico. Dentro dessa visão, os fatores que prejudicaram o subsequente desenvolvimento da estrutura tecnológica de Campinas são relacionados à insuficiente interação entre os elementos constituintes dessa unidade tecnoprodutiva. Na perspectiva de D’Ávila, a estrutura de apoio a C\&T das últimas décadas se caracterizou por uma atuação errática e fragmentária, impedindo a construção de projetos mais ambiciosos. Ambos intelectuais partem do principio de que o entendimento das atuais condições do polo tecnológico de Campinas só pode ser efetivamente dimensionado caso se leve em conta as estruturas de amparo e os interesses que atualmente mobilizam as relações entre a sociedade, política, economia e C\&T. 


\section{CONSIDERAÇÕES FINAIS}

Fazer o balanço do processo desenvolvimentista para a C\&T durante o regime militar é uma tarefa complexa. Dada às múltiplas repercussões e inúmeros descaminhos percorridos nessa marcha modernizante, torna-se necessária uma análise crítica do resultado desse episódio. Analisar criticamente tais resultados é uma condição, dado que os fatores colocados em questão estão entremeados pelos diversos vetores históricos que contingenciavam o momento.

Nessas considerações finais buscaremos retomar algumas das discussões tratadas na dissertação de maneira a poder elaborar uma síntese do processo. Também vamos propor algumas reflexões sobre os objetivos e consequências da estrutura desenvolvimentista colocada em marcha pelo regime ditatorial.

Partimos do entendimento de que o planejamento econômico empreendido pelos militares e o pacto de classes que sustentava tal estrutura foi determinante nos rumos e limites desse processo. O sentido histórico assumido pelas iniciativas promovidas pela busca do desenvolvimento com segurança impediu qualquer projeto ou visão que destoassem do horizonte autoritário que cercou o Brasil a partir do golpe militar.

Conforme observamos no primeiro capítulo dessa dissertação, a questão do desenvolvimento econômico era um termo em disputa entre os grupos e as classes sociais que compunham as forças políticas da sociedade brasileira. Sabemos que esse enfrentamento não ocorreu apenas no campo da teoria, grandes tensões e violências decidiram os rumos para os quais o país se encaminharia.

O direcionamento autoritário das demandas desenvolvimentistas circunscreveu as possíveis interlocuções admissíveis à elite técnico-burocrática que planejou as políticas colocadas em prática nas décadas seguintes. Ou seja, aos planejadores da política econômica, científica e tecnológica do regime militar eram aceitas teorias e influências que não conflitassem com a Doutrina de Segurança Nacional. Em um mundo regido pela bipolaridade capitalismo/comunismo, as tensões ideológicas e sociais enevoavam as discussões sobre termos supostamente regidos pela fria racionalidade técnica e científica. 
Sabemos que a intransigência ideológica é uma constante na História das Ideias. O específico da situação brasileira, a partir de 1964, talvez esteja no quão limitado era o campo de reconhecimento e diálogo possível com o Estado. O regime militar adotou posturas acentuadamente intransigentes em nome da Doutrina de Segurança Nacional. $\mathrm{O}$ isolacionismo dessa atitude afetou até aliados e parceiros próximos, que muitas vezes denunciaram tais posturas em documentos públicos, videm os inúmeros comentários oficiais do governo dos Estados Unidos, de documentos do FMI ou do Banco Mundial, de relatórios e denúncias da Anistia Internacional, Cruz Vermelha, ONU e muitas outras $^{83}$.

A construção da estrutura científica e tecnológica era amparada pelo Modelo Brasileiro de Desenvolvimento, ou seja, enquanto o sistema econômico planejado pelo regime militar foi bem sucedido, o apoio à área da pesquisa e da ciência era garantido por parte do Estado.

Entretanto tal disponibilidade de investimentos além de episódica estava assentada em bases frágeis. A década de 1980 viu o desmonte gradual dessa estrutura. O reflexo desse processo para a C\&T nacionais foram sentidos nos enormes cortes orçamentários e restrições de verbas para os setores envolvidos em P\&D no país.

Processo contraditório e complexo, pois ao mesmo tempo em que a construção da estrutura de apoio às demandas da $\mathrm{C} \& \mathrm{~T}$ formou profissionais engajados na ideologia modernizadora, também se formou um substrato crítico capaz de avaliar objetivamente os caminhos e descaminhos tomados pelo regime militar. $\mathrm{Na}$ hora em que as perdas tornaram-se insustentáveis, esses profissionais não aceitaram passivamente tais circunstâncias, a partir desse momento abriu-se uma frente organizada responsável por pressionar social e politicamente o Estado em busca de alternativas (MOTOYAMA, 2004). A postura desse grupo e da sociedade brasileira encaminharam os espaços de sustentação para a C\&T nacionais nas décadas seguintes, mesmo que as perspectivas nunca mais fossem tão radiantes quanto às imaginadas nas décadas anteriores.

\footnotetext{
${ }^{83}$ Uma análise sobre as tensões entre os EUA, instituições internacionais e o Brasil, pode ser vista em: SKIDMORE, 1988, p.179-180, 184.
} 
Contudo, ao observarmos o desenvolvimento desses eventos, faz-se claro o entendimento de que o momento em que as demandas científicas e tecnológicas se subordinaram aos desígnios do planejamento econômico desenvolvimentista é o instante onde a sorte da C\&T foi lançada. Os resultados desse jogar de dados já estava determinado em sua própria origem, e não foi necessária capacidades divinatórias para a leitura desse destino, as análises criteriosas de diversos pesquisadores apresentavam a provável fortuna da estrutura sociopolítica colocada em marcha. Repetiu-se uma velha ironia histórica, as vozes hegemônicas normalmente ditam os caminhos a serem percorridos, mesmo quando tais vozes estão em franca contradição com a realidade. $\mathrm{O}$ conservadorismo e autoritarismo pagaram o preço de sua aposta intransigente na Doutrina de Segurança Nacional.

Para entender as circunstâncias e debates que contingenciavam a formação do polo tecnológico de Campinas é preciso recuperar esse ambiente complexo no qual os interesses pragmáticos das forças políticas e econômicas encontravam a iniciativa criadora de pesquisadores e cientistas que também tinham seus projetos e visões de desenvolvimento social.

Entretanto nossa análise não se limita ao momento de vigência do Modelo Brasileiro de Desenvolvimento para entender a formação da estrutura do polo tecnológico em Campinas. Ao abordarmos o surgimento desse polo, privilegiamos avaliar como as dinâmicas históricas locais criaram condições para que projetos e ideias exteriores as dinâmicas da região fossem acolhidos e estruturassem uma nova etapa econômica na cidade.

Entendemos que a região de Campinas, por sua particularidade histórica, mobilizou demandas específicas que foram fundamentais para o surgimento de uma grande universidade voltada à pesquisa e o consequente surgimento de um polo associado a essa instituição.

Nesse processo, verificamos que a produção agrícola cafeeira foi determinante para o aparecimento de uma estrutura fabril, e que o desenvolvimento industrial condicionou o crescimento urbano, assim como uma infraestrutura atraente na cidade de Campinas. Junto a isso devemos considerar todas as demandas próprias de um universo 
que compartimentava em si as necessidades agrícolas, e também as instâncias próprias de um caráter urbano cada vez mais acentuado.

O processo de crescimento econômico local permitiu que as necessidades da emergente elite campineira fossem atendidas pelo governo estadual e federal. No tocante ao campo da C\&T, área determinante para o surgimento de um polo tecnológico, verificamos em nossa análise que, desde a etapa agrícola, a relação entre a estrutura de $P \& D$ e o setor produtivo sempre foi próxima. Tal articulação inicialmente foi proporcionada pelas atividades do IAC, posteriormente a Unicamp assumiu esse mesmo perfil ao determinar que um dos seus objetivos fundamentais era o de buscar soluções às demandas sociais através do ensino e pesquisa científica ${ }^{84}$. Nesse momento de formação, a universidade voltou-se aos grandes problemas nacionais e dessa iniciativa as estruturas de P\&D do polo tecnológico foram constituídas.

Cabe também ressaltar que a ideia de criação de uma unidade produtiva baseada no conhecimento técnico científico foi implementada em Campinas graças à atuação de alguns professores da Unicamp.

Tais professores ao se fixarem na cidade trouxeram, junto de sua bagagem intelectual, um modelo de produção ainda não implantado na região, mas muito bem sucedido em algumas áreas dos Estados Unidos. Da tentativa de transplantar tal estrutura produtiva para a região, criou-se um polo tecnológico.

É importante novamente ressaltar que a existência da estrutura de P\&D mobilizada na construção do polo tecnológico só foi possível graças a uma conjuntura política singular. $\mathrm{O}$ regime militar incorporou ao planejamento econômico a necessidade de aproximação com a C\&T. A partir de então, disponibilizou-se recursos para projetos de pesquisa que se voltassem ao desenvolvimento de tecnologias necessárias ao crescimento econômico do país.

Conforme nossa pesquisa demonstrou, o Estado, aproveitando-se da infraestrutura desenvolvida nas décadas anteriores, instalou na região de Campinas uma grande estrutura de P\&D para apoiar o seu projeto desenvolvimentista. Também

\footnotetext{
${ }^{84}$ Entrevista com Zeferino Vaz.
} 
demonstramos que a participação ativa de pesquisadores/professores da Unicamp foi fundamental para a criação e desenvolvimento dessa estrutura.

Avaliando em sua origem, podemos dizer que o a formação e desdobramento do polo tecnológico de Campinas é resultante das circunstâncias enfrentadas pelo Modelo Brasileiro de Desenvolvimento. Tal afirmativa se justifica ao observamos que o setor de P\&D se constituiu em torno dos projetos desenvolvimentistas do regime militar. Outro ponto que demonstra essa questão é a constatação de que a ligação com as demandas governistas se mostrou extremamente limitadora em um momento de desarticulação da estrutura desenvolvimentista.

A crise de financiamento enfrentada pelas instituições de pesquisa da cidade reduziu em muito as expectativas em torno do polo tecnológico. Em sua análise sobre o polo tecnológico de Campinas, Paulo Roberto Joia (2000, p. 241), identificou o seguinte cenário nos anos 90:

Com a retirada do governo (ou retração de sua atuação), as características de cada componente teriam se modificado, criando uma combinação de elementos ou um conjunto final - diversa daquela encontrada em polos tecnológicos de países centrais. Hoje, o destino do polo tecnológico está a mercê das diretrizes tomadas pelas multinacionais que, num país periférico em relação ao capitalismo mundial, são bastante volúveis.

Acreditamos que se compararmos o projeto de Campinas com o modelo mundial de polo tecnológico, o Vale do Silício, veremos que a estrutura desenvolvida nessa região nunca se assemelhou a sua fonte inspiradora. Principalmente devido à pequena participação da iniciativa privada, limitado alcance do empreendedorismo, e claro, a inexistência de massivos investimentos públicos nas pesquisas desenvolvidas pelas instituições de C\&T locais.

Por outro lado, não é exagerado afirmar que, em sua origem, existiam elementos muito interessantes sendo conjugados nesse polo tecnológico. Especialmente se considerarmos que, da estrutura de $\mathrm{P} \& \mathrm{D}$ desenvolvida na cidade, o país passou a possuir tecnologia própria para a fabricação de mais de uma centena de produtos nas áreas de telecomunicações, microeletrônica, medicamentos, química e setor metal 
mecânico. Produtos esses que inclusive eram fabricados nas indústrias de alta tecnologia da cidade (JOIA, 2000).

A crítica elaborada pela bibliografia que analisa a estrutura desse polo tecnológico se concentra em observar que essa capacidade industrial não pode ser plenamente aproveitada pela indústria nacional. $\mathrm{O}$ fim da reserva de mercado e da lei de informática abriu espaço para o avanço das multinacionais. Essas indústrias não desenvolviam suas principais tecnologias na região por contarem com laboratórios de P\&D instalados nos grandes polos tecnológicos dos países centrais. Nesse meio tempo, as indústrias locais de tecnologia passaram a ser simples produtoras de equipamentos e/ou softwares terceirizados pelas grandes companhias internacionais, ou então ocuparam o mercado montando produtos tecnológicos fabricados no exterior. Tais empresas nacionais instaladas em Campinas apresentaram uma tendência de se afastar cada vez mais da estrutura de P\&D presentes na cidade, concomitantemente, a estrutura voltada a amparar as empresas de base tecnológica não conseguiu recuperar o ambiente voltado à inovação e pesquisa tecnológica ${ }^{85}$.

Do ponto de vista social, observamos que a inicial expectativa em torno da nascente indústria tecnológica se mostrou exageradamente otimista quanto às possibilidades de crescimento econômico, geração de emprego e distribuição de renda para os habitantes desse polo tecnológico.

Em 1995, a Fundação SEADE (Fundação Sistema Estadual de Análise de Dados) publicou um levantamento estatístico das condições de vida, saúde, educação e emprego da população campineira, esses dados refletem as condições existentes na cidade no ano de $1994^{86}$. Os resultados desse estudo confirmam algumas das hipóteses críticas quanto aos resultados econômicos e sociais de um polo tecnológico. Tal unidade produtiva, ao contrário da propagada noção de que eventualmente ajudaria a equilibrar

\footnotetext{
85 Bibliografia sobre o polo de Campinas: DE MATTOS, M. 1990. Polos Tecnológicos: Um Estudo de Caso; GOMES, E. J. 1995. A Experiência Brasileira de Polos Tecnológicos: Uma Abordagem Político Institucional. GOMES, E. J. 1998. Imaginário e Realidade em Torno dos Parques e Polos Tecnológicos: Elementos Para Reflexão; JOIA, P. R. 2000. Novas Trajetórias da Alta Tecnologia no Brasil, Sob Influência da Ação do Estado: Uma Análise do Polo Tecnológico Regional de Campinas-SP; LIMA, L. C. 1997. Tecnopolo: A Formação de Uma Nova Territorialidade; SANTOS, R. C. B. 2005. Campinas Como Polo Tecnológico na Reestruturação do Espaço Urbano Regional; TAVARES, H. M. 1997. Complexos de Alta Tecnologia e Reestruturação do Espaço.

${ }^{86}$ O resultado desse estudo foi publicado em: SEADE. 1995. Pesquisa de Condição de Vida: Campinas, Primeiros Resultados.
} 
as demandas sociais de um território, na verdade, em sua atuação, percebemos a tendência a acentuar o desenvolvimento desigual, pois as estruturas mobilizadas na constituição de um polo diferenciam e hierarquizam o espaço, até mesmo gerando um crescente distanciamento entre os trabalhadores possuidores de conhecimento científico dos que não o possuem (TAVARES, 1997). Ou seja, pretender que com a simples instalação de um polo tecnológico resolveria parte dos problemas associados à desigualdade social implica-se em um erro de entendimento do funcionamento das estruturas hierarquizantes que condicionam as iniciativas econômicas e sociais dadas em ambientes caracterizados pelo desenvolvimento desigual.

No estudo promovido pelo SEADE fica evidente que após uma década de atuação do polo tecnológico a população da cidade ainda enfrentava os graves problemas de desigualdade social típicos da sociedade brasileira. Podemos citar alguns dados dessa pesquisa para comprovar tal afirmativa:

Considerando o acesso à educação, $40 \%$ das familias da cidade eram carentes de instrução - e nas familias de situação econômica mais precária, 75\% desse grupo, não tinham concluído sequer os quatro primeiros anos do atual ensino fundamental. A presença de famílias negras era minoritária nos grupos sociais mais abastados $(4,7 \%)$, sendo proporcionalmente predominante nos grupos extremamente empobrecidos e em situação de miséria $(37,1 \%$ e $52,4 \%$, respectivamente). A distribuição de renda apresentava altos índices de concentração, uma família empobrecida dispunha de apenas $14 \%$ da renda de uma família abastada. Se considerarmos nas estatísticas a renda familiar per capita, as diferenças entre os grupos se amplificam, dado o fato das famílias empobrecidas, na média, possuírem mais membros. Se continuarmos esmiuçando os dados verificaremos uma sociedade onde crianças de famílias empobrecidas ainda eram responsáveis por parte significativa da renda familiar, onde mulheres negras e pardas recebiam rendimentos significativamente menores que mulheres brancas e amarelas, onde pais de família empobrecidos enfrentavam grandes dificuldades de inserção no mercado de trabalho e o emprego, quando conquistado, era caracterizado pela baixa renda e alta rotatividade, outro dado ilustrativo mostra que a infraestrutura dos bairros periféricos era consideravelmente inferior a dos bairros abastados, pois a população 
convivia com dificuldade em conseguir do poder público estruturas básicas, como asfalto e saneamento (SEADE, 1995).

Analisando o estudo realizado pela SEADE, veremos que inúmeros são os dados que representam uma sociedade com altas taxas de desigualdade. Entretanto, nos chamou a atenção uma informação que em nossa perspectiva analítica demonstra o grau de cisão entre os trabalhadores que possuem o conhecimento científico, dos que não o possuem:

No grupo A (grupo que pode ser definido como o extremo superior da escala econômica elaborada pelo SEADE, este grupo agregava 32,5\% das famílias de Campinas em 1994. Comparadas às demais, estas famílias possuem maior nível de instrução, condições habitacionais mais satisfatórias, menor vulnerabilidade de inserção no mercado de trabalho e renda per capita mais elevada) é bem mais expressiva a proporção de assalariados do setor público e de empregadores (incluídos os donos de negócio familiar e os professores universitários autônomos) e onde se observa a menor proporção de assalariados do setor privado, que não chega a 50\% (SEADE, 1995, p.70).

Esses trabalhadores do grupo A, que ocupam lugar nas universidades, que realizam as atividades produtivas do polo tecnológico com suas empresas de médio e pequeno porte, que trabalham nas enfraquecidas, mas ainda existentes instituições de P\&D da cidade, socialmente se encontravam em uma situação de singularidade em relação ao seu entorno. Pois, apesar de enfrentarem os problemas do avanço das medidas neoliberais, ainda conseguiam se preservar das dinâmicas mais agressivas dessa nova etapa econômica. Viviam e trabalhavam em locais privilegiadas em relação à atenção do Estado, usufruindo de modo de vida pouco semelhante ao dos outros grupos sociais da cidade.

Dessa maneira, consideramos que a análise efetuada por Tavares, que avalia os polos tecnológicos a partir do enfoque da reestruturação do espaço e do processo de concentração dos fatores de produção (TAVARES, 1997), extremamente ilustrativa para o entendimento dessa unidade na cidade de Campinas.

Se buscarmos as discussões e projetos expostos no início da história dessa unidade produtiva, e se considerarmos os discursos que procuravam legitimar a 
construção do polo tecnológico, ou seja, se pensarmos no alcance desse projeto, que inicialmente foi concebido com muitos dos elementos de uma utopia técnico-científica, veremos que os custos sociais não retornaram os dividendos imaginados, nem para a indústria nacional de alta tecnologia, que se desmobilizou com o avanço do capital internacional, nem para a população local, que em sua maioria ficou alheia aos resultados positivos desse processo.

Tal desfecho, que pode ser enunciando como decepcionante, na verdade nos fornece a oportunidade de perceber dinâmicas históricas que passariam despercebidas caso a estrutura montada na região se configurasse um desmedido sucesso.

Talvez uma das questões centrais desse processo esteja no próprio alcance das ideias e empreendimentos colocados em movimento na cidade de Campinas. Ver o fracasso do Modelo Brasileiro de Desenvolvimento, e a consequente crise que se instalou no campo da C\&T, nos permite perceber como a marcha desenvolvimentista encetada no Brasil desse período estava em descompassado com as dinâmicas múltiplas e imprevistas das forças históricas. O planejamento estruturante, usando da planificação econômica, não conseguiu antever, ou mesmo responder pertinentemente às crises que abalaram a estrutura construída. Sobre essa questão o historiador E. Hobsbawm comenta:

\footnotetext{
A ciência social moderna, a política e o planejamento adotaram um modelo de cientificismo e manipulação técnica que, sistemática e deliberadamente negligencia o humano e, acima de tudo, a experiência histórica (HOBSBAWM, 2013, p. 48).
}

Em Campinas fatores como a estrutura política local e seus conflituosos interesses, a dinâmica econômica nacional e suas limitações, a dependência universitária de um enfraquecido sistema de patrocínio a C\&T, são todos elementos que corroeram o processo desenvolvimentista tecnológico. Tais elementos, quando não insuspeitos, não foram superados pela iniciativas locais e federais.

Entretanto precisamos discutir o lugar da Utopia, que nos anos finais do século $\mathrm{XX}$, momento onde a perspectiva de superação das condições estruturais do capitalismo entrava em profunda crise, passou a ser vista, não apenas como infundada, mas também 
perigosa. Ponderando sobre os limites do pensamento utópico, R. Jacoby resgata Hegel para encaminhar essa questão:

\begin{abstract}
"Mesmo ao se compreender a história como o altar de sacrifícios em que foram vitimadas a felicidade dos povos, a sabedoria dos Estados e a virtude dos indivíduos - a questão surge involuntariamente - a que princípios, a que objetivo final esses enormes sacrifícios foram oferecidos?" Podemos hoje dizer que os utopistas são os responsáveis? (JACOBY. 2007, p. 46)
\end{abstract}

A esse desafio acreditamos ter fornecido algumas respostas em nossa pesquisa quando demonstramos a quais propósitos o planejamento econômico do regime militar e a Doutrina de Segurança Nacional se voltavam, e como essa estrutura incorporou a C\&T em seus projetos. Se sintetizarmos os objetivos desses projetos de ordenamento social veremos que em sua raiz está a repressão política ideológica, a manutenção de uma estrutura de poder conservadora, o uso da ideologia nacionalista como legitimadora de violências e quebra de liberdades. Não podemos imputar a nenhum desses objetivos valores utópicos.

Também consideramos o alerta proferido por R. Jacoby em seu ensaio sobre o pensamento utópico, como pertinente para a manutenção dessa corrente de pensamento nos anos vindouros. Para Jacoby, a tradição majoritária do pensamento utópico se destaca por seu caráter projetista, ou seja, uma longa tradição de pensadores se esforçou em estipular em mínimos detalhes os seus projetos futuros. Ao descrever o desgaste desse pensamento, o autor procura na história da utopia um modesto grupo de eruditos que ao se voltar ao futuro evitaram cair na armadilha de projetar suas aspirações em modelos completos e fechados. Tais pensadores preferiam preservar seus princípios fundamentais - princípios comunitários, estéticos, morais, filosóficos, religiosos - a cair na armadilha da predição e projetamento. O ensaio se esforça em demonstrar como essa alternativa pode reconciliar nossa necessidade de buscar um devir melhor, ao mesmo tempo em que evita as frustrações e sofrimentos causados por projetos preconcebidos, sempre em defasagem com a história e sua constante transformação. Para Jacoby:

Se o futuro desafia a representação, não desafia, no entanto, a esperança. Os utopistas iconoclastas eram utopistas contra a corrente. Não se renderam ao toque do tambor das emergências cotidianas, também não pintaram uma utopia 
em cores reluzentes. Eles mantiveram seus ouvidos atentos a longínquos sons de paz e alegria, de um tempo em que, como disse o profeta Isaías, "o leão comerá palha como o boi” (Isaías, 11:7). Podemos aprender com eles (JACOBY. 2007, p.20).

Enunciar um modelo utópico baseado no ideal iconoclasta parece ter fundamento em um mundo dominado pela efemeridade das imagens, pela transitoriedade da propaganda e seu apelo visual, pela fugacidade das modas e valores. Cabe ao cientista, ao político, ao intelectual, ao cidadão que mui precariamente participa do processo de escolha política, não cair na armadilha do projetismo, ter noção que os múltiplos e imprevisíveis vetores históricos resistem ao martelo e bigorna do planejamento inflexível.

Para concluirmos nossa reflexão não podemos deixar de abordar as entrevistas com os cientistas e intelectuais que mobilizaram seus recursos e imaginação na estruturação do polo tecnológico de Campinas, tais entrevistas consistiram em uma das principais fontes utilizadas para a análise da formação da estrutura desse polo tecnológico.

A primeira questão que gostaríamos de abordar sobre esse tema é relacionada à especificidade do trabalho de análise histórica que se utiliza de fontes orais. Ao mesmo tempo em que o método de análise e checagem da entrevista não difere essencialmente da metodologia empregada na análise de outras fontes, por outro lado vemos que o depoimento constitui-se um documento no qual o historiador tem uma proximidade maior, já que teve participação ativa na elaboração de seu conteúdo.

Tal familiaridade, delineada durante o desenvolvimento da pesquisa, não pressupõe uma abordagem descuidada, ou presunçosa. Longe disso, dedica-se uma atenção e cuidado maior na elaboração da análise, principalmente devido ao conteúdo humano manifestado no material abordado. Sobre essa questão cabe citar uma interessante observação:

À medida que se escreve, tem-se consciência das pessoas com quem se conversou; hesita-se em atribuir a suas palavras significados que elas se recusariam. Humana e socialmente, essa é uma cautela conveniente; e, na verdade, os antropólogos tem demonstrado que é igualmente fundamental para a compreensão científica (THOMPSON.1994, p.305). 
Se o maior pecado que pode ser cometido por um historiador é o anacronismo (FEBVRE, 2009), ou seja, imputar valores atuais a crenças, ideias ou hábitos existentes em tempos passados; a fonte oral, com suas peculiaridades, talvez traga um considerável teste de conviç̧ão ao fazer historiográfico. Pois, além do cuidado com a dimensão histórica de conceitos que podem parecer corriqueiros a nossa experiência, mas que carregam em si particularidades únicas no período no qual é mobilizado - basta refletir no grau de transformação que o nacionalismo como conceito sofreu durante o século XX, do caráter modernista assumido pela geração de 1920, foi remodelado dentro da visão fascista defendida pelo integralismo, até a construção da perspectiva nacional ufanista propagandeada pelo regime militar e ainda hoje mobilizada em outras conjunções de perfil conservador - também é preciso uma maior atenção à própria biografia do enunciador do conceito.

O entrevistado expõe suas ideias muitas vezes buscando sua história de vida como justificadora de atitudes, visões de mundo, ou mesmo omissões. Dessa maneira é preciso qualificar esse processo para que os significados atribuídos não escampem da história do indivíduo analisado.

Podemos exemplificar essa questão recuperando o depoimento onde Saul D'Ávila apresenta como os pesquisadores da COPPE reagiam ao caráter repressivo do governo militar. A abordagem literal ao trecho destacado poderia levar a uma análise que apresenta o entrevistado e seus pares como indivíduos em consonância com as atitudes repressivas, ou que ao menos abordavam tal momento dentro uma grande permissividade com os descaminhos tomados pelo regime. Entretanto se recuperarmos e analisarmos o depoimento completo, no qual o pesquisador narra sua juventude altamente influenciada pelo desenvolvimentismo praticado pelo governo do presidente Juscelino Kubitschek, e como a ideia dos "cinquenta anos em cinco" mobilizou sua geração, teremos um panorama com matizes muito mais complexos que o simples postulado repressão/resistência, conforme demonstramos em nossa análise no último capítulo da dissertação.

Dentro dessa questão, a fonte oral permite ao historiador perceber o constante conflito entre a liberdade e o determinismo, entre a estrutura social e ação humana (FREITAS, 2006). A singularidade é inerente ao depoimento, cabe ao pesquisador 
respeitar a experiência do indivíduo, cuidando de explicá-la em seu contexto e possibilidades.

Dessa maneira, ao abordarmos as entrevistas utilizadas na pesquisa procuramos demonstrar como diferentes indivíduos, com percursos históricos, ideologias e interesses particulares se relacionaram com sua conformação social e histórica de maneira a realizar seus projetos e visões de mundo.

O comum a essas narrativas é o subtexto do desenvolvimento nacional, do administrador universitário ao pesquisador que desenvolve a tecnologia pioneira, observamos na fala de todos esses intelectuais o esforço em conciliar a ciência com os objetivos econômicos do país. Essa característica marcante é ressignificada na história de vida de cada um dos indivíduos participantes desse momento.

Outro objetivo proposto nessa dissertação era o de avaliar o resultado do projeto historiográfico proposto por Certeau. Usar a fonte oral em comparação com os modelos explicativos demonstrou, em primeiro lugar, que a historiografia que aborda esse período é sofisticada a ponto de se aproximar muito satisfatoriamente da experiência individual dos indivíduos analisados, no caso, os intelectuais envolvidos com a C\&T durante o regime militar.

Não percebemos nenhuma "quebra" significativa nos modelos interpretativos sobre o período em questão. A teoria histórica contempla as diferentes vivências pessoais, apresenta a estrutura governamental e seus projetos, assim como descreve com verossimilhança o perfil das instituições e sociedade do período.

Em contrapartida, os depoimentos permitiram a apreciação de nuances que escapam a historiografia geral sobre tais conteúdos. Conseguimos mapear a ação individual que em alguns momentos permitiu o rompimento de determinismos, abrindo espaços de realização graças à potencialidade imanente a ação humana. Uma das principais dinâmicas de negociação que sobressaem nesses depoimentos é o valor das relações interpessoais, que em alguns momentos consegue cooptar as estruturas de poder em prol de interesses particulares. Tais dinâmicas são escassamente analisadas pelas obras que abordaram tal período. Entretanto, graças ao depoimento oral, conseguimos demonstrar como a mobilização do valor personalista, e as dinâmicas sociais próprias do compadrio, tiveram importante papel na construção da estrutura de 
P\&D da Unicamp. Foi por esse caminho que Zeferino Vaz conseguiu mobilizar o ortodoxo Ministério da Fazenda a favor do projeto de universidade em Campinas. Contou nesse episódio com a força de suas relações pessoais e o status conseguido junto ao regime.

Por último, entendemos que a transcrição dos depoimentos - mesmo que em fragmento, devido às limitações da própria estrutura discursiva da dissertação - de alguns dos responsáveis pelo início de um projeto significativo para o período histórico estudado é relevante por destacar o valor e os limites da ação humana. É preciso resgatar a voz do indivíduo que ao se defrontar com as estruturas de sua época constrói seu mundo, negociando os espaços de sua existência e em última instância, realizando as possibilidades de seu tempo. Nessa dimensão individual também devemos reconhecer a ação da história, que para além das abstratas estruturas teóricas, se desenrola na práxis da vida cotidiana.

\section{PARTE III - Documentação e Referências Bibliográficas}

\section{Elenco da documentação}

Entrevistas

José Ellis Ripper. Na sede da empresa AsGa, em 29 julho, 2015.

Saul Gonçalves d'Ávila. Na sua residência, em 22 de julho, 2015.

Rogério Cezar de Cerqueira Leite. Na sua residência, em 02 de julho, 2015.

Rogério Cezar de Cerqueira Leite. 19 dezembro, 1977. Rio, FGV/CPDOC História Oral, 1986 (História da Ciência - Convênio FINEP/CPDOC).

Zeferino Vaz. 12 de janeiro, 1977 e 13 de janeiro, 1977. Rio, FGV/CPDOC História Oral, 1986 (História da Ciência - Convênio FINEP/CPDOC).

\section{Jornais e Periódicos}

Folha de S.Paulo, 08 jul. 1976. , 27 ago. 1978. , 19 nov. 1978. , 17 fev. 1979. 
,03 ago. 1979

, 04 ago. 1979.

, 12 ago. 1979.

, 25 ago. 1979.

, 20 set. 1979.

, 06 nov. 1979.

, 02 fev. 1980.

, 08 nov. 1980.

, 06 dez. 1980.

, 05 abr. 1981.

, 21 abr. 1981.

, 25 jun. 1981.

, 27 mar. 1982.

, 03 jul. 1982.

, 13 jan. 1983.

, 15 jan. 1983.

, 23 jun. 1983.

, 19 ago. 1983

, 15 out. 1983.

, 03 dez. 1983.

, 20 jun. 1984.

, 15 ago. 1984

, 22 ago. 1984.

, 28 ago. 1984.

, 29 ago. 1984.

, 09 nov. 1984.

, 18 set. 1985.

, 03 out. 1985.

, 12 out. 1985.

, 17 nov. 1985.

, 10 dez. 1985. 
, 15 jun. 2015.

O Estado de São Paulo, 26 novembro, 1971.

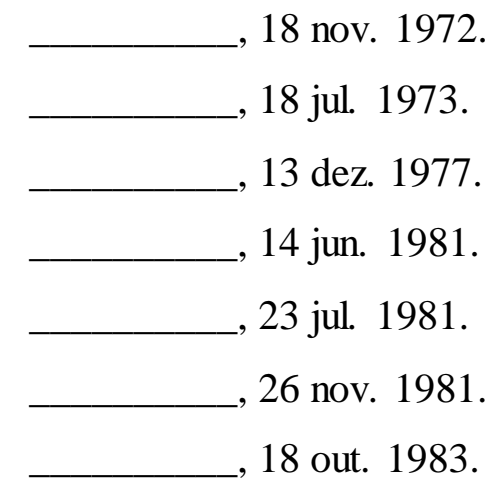

Pesquisa Fapesp, n.101, jun. 2014.

\section{Bibliografia}

ALBERTI, V. (org). História Oral: desafios para o século XXI. Rio de Janeiro: Editora Fiocruz/ casa de oswaldo cruz/CPDOC- Fundação Getúlio Vargas, 2000.

ALBERTI, V. Manual de História Oral. Rio de Janeiro, FGV, 2008.

ALMEIDA, B. H. O Outro Lado [da História] das Telecomunicações: A Saga do Padre Landell. Porto Alegre, Sulina/ARI, 1983.

ALVES, Maria Helena Moreira. Estado e Oposição no Brasil (1964-1984). Bauru/SP: Edusc, 2005

AQUINO, M. A. Censura, Imprensa, Estado Autoritário (1968-1978). Bauru, EDUSC, 1999.

ARFUCH, L. O Espaço Biográfico: Dilemas da Subjetividade Contemporânea. Trad. P. Vidal. Rio de Janeiro: EdUERJ, 2010.

ARTIÈRES, Ph. Arquivar a Própria Vida. Revista Estudos Históricos, Marilia, v. 11, n. 21, p. 9-34, 1998.

BADARÓ, R. C. Campinas - O Despontar da Modernidade. Campinas, CMU, UNICAMP, 1996.

BELL, D. The Measurement of Kownledge and Technology, in Eleanor Sheldon and Wilbert Moore, Eds., Indicators of Social Change. Nova Iorque. 1969

BERGó, M. E. A. Estudo Geográfico da Cidade de Campinas. Anais do X Congresso Brasileiro de Geografia. Vol.3, São Paulo, 1952.

BIELSCHOWSKY, R. Pensamento Econômico Brasileiro: O Ciclo Ideológico do Desenvolvimentismo. Rio de Janeiro: Contraponto, 2000. 
BOBBIO, N. O Tempo da Memória: De Senectute e Outros Escritos. Rio de Janeiro: Campus, 1997.

BOSI, A. Dialética da Colonização. São Paulo, Cia. das Letras, 1999.

BOSI, E. Memória e Sociedade, Lembranças de Velhos. 2. ed. São Paulo: Companhia das Letras, 1994.

BOSI, E. O Tempo Vivo da Memória: Ensaios de Psicologia Social. 2. ed. São Paulo: Ateliê Editorial, 2003.

BORGES, Nilson. A Doutrina de Segurança Nacional e os Governos Militares. IN: FERREIRA, Jorge; DELGADO, Lucilia de Almeida Neves (orgs.). O Brasil Republicano: O Tempo da Ditadura: Regime Militar e Movimentos Sociais em Fins do Século XX. Rio de Janeiro: Civilização Brasileira, 2003, pp. 13-42.

BOURDIEU, P. A ilusão biográfica. In: FERREIRA, M. M.; AMADO, J. (orgs.). Usos \& Abusos da História Oral. Rio de Janeiro: Fundação Getúlio Vargas, p. 183-191, 1996.

BRAGA, E. S. A Constituição Social da Memória: Uma Perspectiva HistóricoCultural. Ijuí: Unijuí, 2000.

BRAGA, E. S. Apontamentos Sobre a Memória do Futuro. In: DA ROSS, S. Z.; MAHEIRIE, K.; ZANELlA, A. V. (orgs.). Relações Estéticas, Atividade Criadora e Imaginação: Sujeitos e (Em) Experiência. Florianópolis: NUP/CED, v. 1, 2006, p. 177194.

BRAGA, E. S.; SMOLKA, A. L. B. Memória, Imaginação e Subjetividade: Imagens do Outro, Imagens de Si. Horizontes, Bragança Paulista, v. 23, n. 1, p. 19-28, jan./jun, 2005 .

BRASIL. Escola Superior de Guerra. Manual Básico. Rio de Janeiro, ESG, 1976.

BRAUDEL, F. História e Ciências Sociais. Lisboa, Ed.Presença, 1986.

BRENNER, Robert. O Boom e a Bolha: Os EUA na Economia Mundial. Rio de Janeiro, Record, 2003.

BRESCIANI, S.; NAXARA, M. (orgs.). Memória e (Res)Sentimento: Indagações Sobre Uma Questão Sensível. Campinas, SP: Editora da UNICAMP, 2001.

BRZEZINSKI, Z. América: Laboratório do Mundo: A Era da Tecnetrônica \& o Desafio Universal. Traduzido por J. A. Fortes; Rio de Janeiro: Ed.Artenova, 1971.

CAMARGO, A. História Oral e Política. In: FERREIRA M. de M. (Org.) História Oral e Multidisciplinaridade. Rio de Janeiro, CPDOC/Diadorim/Finep, 1994, p. 78-105.

CAMPINAS: Subsídios Para a Discussão do Plano Diretor. Campinas, Prefeitura Municipal de Campinas, 1992. 
CANCELLI, E. O Brasil e os Outros: O Poder das Ideias. [recurso eletrônico] / Elizabeth Cancelli. - Dados eletrônicos. - Porto Alegre : EDIPUCRS, 2012. ebooks.pucrs.br/edipucrs/obrasileoso utros.pdf

CANO, W. Raízes da Concentração Industrial em São Paulo. São Paulo, T.A. Queiroz, 1977.

CANO, W.; BRANDÃO, C. A Região Metropolitana de Campinas, Urbanização, Economia, Finanças e Meio Ambiente. Unicamp. 2002.

CARDOSO, F.H. \& FALLETO, E. Dependência e Desenvolvimento na América Latina. Rio de Janeiro: Zahar Editores, 1970.

CASTELlS, M. A Sociedade em Rede. São Paulo: Paz e Terra, 1999.

CASTELLS, M.; HALL, P. Technopoles of the World. The Making of Twenty-FirstCentury Industrial Complex. New York, 1994.

CASTRO, A.B. 7 Ensaios Sobre a Economia Brasileira. Rio de Janeiro: Forense, 1969.

COMBLIN, Joseph. A Ideologia da Segurança Nacional: O Poder Militar na América Latina. Rio de Janeiro: Civilização Brasileira, 1978.

COSTA E SILVA, Sérgio Milliet da. Roteiro do Café e Outros Ensaios. São Paulo, Hucitec/INL, 1982.

COTARElO, R. G. La Utopía en el Mundo Occidental. Guadalajara, Universidad Internacional Menendez Pelayo, 1981.

COULON, A. Escola de Chicago. Campinas, Papirus, 1995.

DANTES, M. A. M. Institutos de Pesquisa Científica no Brasil. In: FERRI, Mário Guimarães; MOTOYAMA, Shozo (Coord.). História das Ciências no Brasil. v.2. São Paulo: EPU: Ed. da Universidade de São Paulo, 1979. p.341-380.

DE CERTEAU, M. Escrita da História. Rio de Janeiro, Forense, 1982.

DELGADO, L.A.N. História Oral, Memória, Identidades. Belo Horizonte, Ed.Autêntica, 2006.

DEMARIO, C.; RIBEIRO, C.; EMILIANO, E.O. A Implementação do Estatuto da Cidade na Região Metropolitana de Campinas. In: BUENO, L.; CYMBALISTA, R. (ORGS) Planos Diretores Nacionais: Novos Conceitos de Planejamento Territorial. P.89-107. Annablume, 2007.

DEMATtOS, M. Polos Tecnológicos: Um Estudo de Caso. 144f. Dissertação (Mestrado) - Universidade Federal de Minas Gerais, Belo Horizonte, 1990.

DIAS, R.B. Sessenta Anos de Política Científica e Tecnológica no Brasil. Campinas, Ed.Unicamp, 2012. 
DINIZ, C.C.; GONÇALVES, E. Economia do Conhecimento e Desenvolvimento regional no Brasil.In: DINIZ, C.C.; LEMOS, M.B. Economia e Território. Belo Horizonte: UFMG. 2005.

FAUSTO, B. A Revolução de 1930: História e Historiografia. São Paulo, Companhia das Letras, 2010.

FEBVRE, L. O Problema da Incredulidade no Séc. XVI: A Religião de Rabelais. São Paulo, Companhia das Letras, 2009.

FERNANDES, A. S. A Reformulação da Doutrina de Segurança Nacional pela Escola Superior de Guerra no Brasil: A geopolítica de Golbery do Couto e Silva. Londrina: Antíteses, vol. 2, n. 4, jul.-dez. de 2009, pp. 831-856.

FERNANDES, F. A Revolução Burguesa. Rio de Janeiro: Zahar Editores, 1974.

FERNANDES, F. Estrutura de Classes e Subdesenvolvimento. Rio de Janeiro: Zahar Editores, 1968.

FERREIRA, J. P. Armadilhas da Memória e Outros Ensaios. Cotia, SP: Ateliê Editorial, 2003.

FERREIRA, Jorge; DELGADO, Lucilia de Almeida Neves (orgs.). O Brasil Republicano: O Tempo da Ditadura: Regime Militar e Movimentos Sociais em Fins do Século XX. Rio de Janeiro: Civilização Brasileira, 2003.

FERREIRA, M. de M.; AMADO, J. Usos e Abusos da História Oral. Rio de Janeiro: Fundação Getúlio Vargas, 1996.

FERREIRA, M. M. (Org.), Entre-vistas: Abordagens e Usos da História Oral, Rio de Janeiro, Ed. Fundação Getúlio Vargas, 1998.

FERREIRA, M. M. (Org.), História Oral, Rio de Janeiro: Diadorim Editora LTDA, 1994.

FERREIRA, M.M; AMADO, J. (Org.), Usos e Abusos da História Oral. Rio de Janeiro, FGV, 2001.

FICO, C. Como Eles Agiam. Os Subterrâneos da Ditadura Militar: Espionagem e Polícia Política. Rio de Janeiro, São Paulo: Record, 2001.

FONSECA, P.C.D. As Origens e as Vertentes Formadoras do Pensamento Cepalino. Revista Brasileira de Economia, Rio de Janeiro, v.54, n.3, p. 333-358, jul/set.2000.

FONSECA, P.C.D; MOLLO, M.L. Metalistas $x$ papelistas: Origens Teóricas $e$ Antecedentes do Debate Entre Monetaristas e Desenvolvimentistas. Nova Economia, Belo Horizonte, MG, vol. 22, núm.2, p. 203-233, mai./ago. 2012.

FORESTER, T. High-Tech Society: The Story of the Information Technology Revolution. Cambridge/Massachusetts: The MIT Press, 1990. 
FORNARI, E. O Incrivel Padre Landell de Moura. Porto Alegre, Ed.Globo, 1960.

FRANK, A.G. Capitalism and Underdevelopment. Latin America, New York, Monthly Review Press, 1969.

FRANK, A.G. Desenvolvimento e Subdesenvolvimento. In: Pereira, L. (Org.) Urbanização e Subdesenvolvimento. Rio de Janeiro: Zahar Editores, 1973.

FREIBERGER, P.; SWAINE, M. Fire in the Valley: The Making of the Personal Computer. Berkeley: Osborne/McGraw Hill, 1984.

FREITAS, S. M. História Oral: Possibilidades e Procedimentos. São Paulo, Editora Humanitas, 2006.

FUKUYAMA, F. O Fim da História e o Último Homem. Rio de Janeiro: Rocco, 1992.

FURTADO, C. Análise do Modelo Brasileiro. Rio de Janeiro: Companhia Editora Nacional, 1972.

FURTADO, C. O Mito do Desenvolvimento Econômico. Rio de Janeiro: Paz e Terra, 1974.

FURTADO, C. Subdesenvolvimento e Estagnação na América Latina. Rio de Janeiro: Editora Civilização Brasileira, 1966.

FURTADO, C. Teoria e Política do Desenvolvimento Econômico. São Paulo: Companhia Editora Nacional, 1967.

FURTADO, C.O. Brasil Pós-Milagre. Rio de Janeiro: Paz e Terra, 1981.

GEBARA, Ademir et al. História Regional: Uma Discussão. Campinas, Editora Unicamp, 1987.

GOMES, E. J. A Experiência Brasileira de Polos Tecnológicos: Uma Abordagem Político Institucional. Dissertação (Mestrado)-Universidade Estadual de Campinas, Campinas, 1995.

GOMES, E. J. Imaginário e Realidade em Torno dos Parques e Polos Tecnológicos: Elementos Para Reflexão. Revista Econômica do Nordeste, vol. 29, n. ${ }^{\circ}$ 4, out./dez. 1998. Fortaleza: Banco do Nordeste, 1998; pp. 481-503.

GUERREIRO, E.P. Cidade Digital: Infoinclusão Social e Tecnologia em Rede. São Paulo: Senac, 2006.

GUIMARÃES, E.A. A Política Científica e Tecnológica. Rio de Janeiro: Jorge Zahar, 1985.

GUIRALDELLI JÚNIOR, P. História da Educação. São Paulo: Cortez, 1992.

HABERMAS, J. Técnica e Ciência Enquanto Ideologia. Os pensadores. São Paulo, Abril Cultural, 1983. 
HOBSBAWM, E. Era dos Extremos: O Breve Século XX. São Paulo: Companhia das Letras, 1995.

HOBSBAWM, E. Sobre História. São Paulo: Companhia das Letras, 2013.

HOLANDA, Sérgio Buarque de. Caminhos e Fronteiras. Rio de Janeiro, Editora José Olympio, 1957.

IAC. Instituto Agronômico de Campinas, 1887-1897: Tem História Para Contar. Campinas, São Paulo: Instituto Agronômico de Campinas, 1987

IBGE. Monografia Histórica do Município de Campinas. Rio de Janeiro, 1952.

JACOBY, R. Imagem Imperfeita: Pensamento Utópico Para Uma Época Antiutópica. Rio de Janeiro, Civilização Brasileira, 2007.

JOIA, P. R. Novas Trajetórias da Alta Tecnologia no Brasil, Sob Influência da Ação do Estado: Uma Análise do Pólo Tecnológico Regional de Campinas-SP. Rio Claro, Universidade Estadual Paulista, Instituto de Geociências e Ciências Exatas, Tese (Doutorado), 2000.

KAWAMURA, L. K. Engenheiros: Trabalho e Ideologia. São Paulo, Ática, 1981.

KUMAR, K. Utopianism. Buckingham, Open University Press, 1991.

LAHORGUE, M. A. Polos tecnológicos no Brasil: Espontaneidade ou Inovação Social? Uma Discussão Sobre Polos Tecnológicos Brasileiros, Suas Evoluções e Perspectivas. In: I Congresso Iberoamericano de Ciencia, Tecnología, Sociedade e Innovación CTS + I, 2006, México D. F. Disponível em: <http//www.oei.es/memoriasctsi/mesa6/m06p34.pdf> Acesso em: 17 fev. 2014.

LE GOFF, J. História e Memória. Campinas, Editora da UNICAMP, 1994.

LIMA, L. C.. Tecnopolo: A Formação De Uma Nova Territorialidade. In: SANTOS, Milton (Org.) et al. Fim de Século e Globalização. 3. ed. São Paulo: Hucitec-Anpur, 1997. p. 285-289.

LURIA, A. R. O Homem Com Um Mundo Estilhaçado. Petrópolis: Vozes, 2008.

MACHADO, M.N.M. Entrevista de Pesquisa: A Interação Pesquisador/Entrevistado. Belo Horizonte - MG: C/ Arte, 2002.

MAGAlHÃES, G. Telecomunicações. In: VARGAS, Milton (Org). História da Técnica e da Tecnologia no Brasil. São Paulo, Editora Unesp-Centro Estadual de Educação Paula Souza,1994.

MANNHEIN, K. Ideologia e Utopia. Rio de Janeiro, Zahar Editores, 1972.

MANTEGA, G. A Economia Política Brasileira. Petrópolis, Vozes, 1984. 
MANTEGA, G. O Pensamento Econômico Brasileiro de 60 a 80: Os Anos Rebeldes. In: LOUREIRO, M.R. (Org.). 50 Anos de Ciência Econômica no Brasil. Rio de Janeiro: Vozes, 1997. p.104-157.

MARCOVICH, J. Parques Tecnológicos e o Desenvolvimento na América Latina. Revista de Administração, São Paulo 23(3): 63-65, julho/setembro 1988.

MARINI, R.M. Subdesarollo y Revolucion. México: Siglo Veintiuno Editores, 1969.

MARKUSEN, A.; HALL, P.; CAMPBELL, S; DEITRICK, S. The Rise of the Gunbelt: The Military Remapping of Industrial America. New York, Oxford University Press, 1991.

MARTINS, L. Pouvoir et Developpement Economique: Formation et Évolution des Structures Politiques au Brésil. Paris, Anthropos, 1976.

MATOS, Odilon N. de. Campinas, das origens até a década de 1930, in Campinas de Ontem e de Hoje. Campinas, Empresas Lix da Cunha, 1988.

MEDEIROS, J. A. Polos Tecnológicos: Ilhas ou Arquipélagos? São Paulo em Perspectiva, São Paulo: Seade, v 9, n. 3, 1995.

MEIHY, J.C. S. B. (org.). (Re) Introduzindo História Oral no Brasil. São Paulo: USP, 1996. p. 1-10.

MEIHY, J.C. S. B. Manual de História Oral. São Paulo, Loyola, 2005.

MELLO, J. M. C. de. O Capitalismo Tardio. São Paulo, editora Brasiliense, 1991.

MELONI, R. A. Ciência e Produção Agrícola. A Imperial Estação Agronômica de Campinas 1887/1897. São Paulo, Dissertação (Mestrado em História Social) - Fac. de Filosofia, Letras e Ciências Humanas, USP, 1999.

MONBEIG, P. Pioneiros e Fazendeiros de São Paulo. São Paulo, Hicitec/Polis, 1984.

MONTENEGRO, A.T. (1994). História Oral e Memória: A Cultura Popular Revisitada. 3ed. São Paulo, Contexto, 1994.

MORAES, R.C.F. O Subdesenvolvimento e as Ideias da Cepal. São Paulo: Ática, 1995.

MORENTE, J. J. (Coord.). Lo Utópico y la Utopía. Barcelona, Integral Ed., 1984.

MOTOYAMA, S. (Org.). Prelúdio Para Uma História: Ciência e Tecnologia no Brasil. São Paulo, EDUSP/FAPESP, 2004.

MOtOYAMA, S. Fapesp: Uma História da Política Científica e Tecnológica. São Paulo: Fapesp, 1999.

MUTLU, S. Inter-regional and Internacional Mobility of Industrial Capital: The Case of American Automobile and Eletronics Industrial. Berkeley: University of California, 1979. 
NOMELI, P. C. B. Associações Operárias Mutualistas e Recreativas em Campinas (1906-1930). Campinas, Dissertação (Mestrado em História) - Instituto de Filosofia e Ciências Humanas, UNICAMP, 2007.

NOVAES, F. Portugal e Brasil na Crise do Antigo Sistema Colonial (1777-1808). São Paulo, Hucitec, 1979.

OLIVEIRA, F. “Economia Brasileira: Crítica a Razão Dualista”. São Paulo, Cebrap, 1972.

OLIVEIRA, M.C.F.A. Questões Demográficas no Período Cafeeiro em São Paulo. Campinas, Unicamp, textos Nepo nº1, 1986.

OLIVEIRA, M. K.; REGO, T. C.; AQUINO, J. G. Desenvolvimento Psicológico e Constituição de Subjetividades: Ciclos de Vida, Narrativas Autobiográficas e Tensões da Contemporaneidade. Pro-Posições. Campinas, SP, v. 17, n. 2, p. 119-138, maio/ago., 2006.

PALLARES-BURKE, M.L.G.. As Muitas Faces da História - Nove Entrevistas. São Paulo, Ed.Unesp, 2000.

PEREIRA, L.C.B. Interpretações sobre o Brasil. In: LOUREIRO, M.R (Org.) 50 anos de Ciência Econômica no Brasil. Rio de Janeiro: Vozes, 1997. p.17-29.

PERKS, R.; THOMSOM, A. (ed.). The Oral History Reader. London/New York, Routledge, 1998.

PRADO, C. A Revolução Brasileira. São Paulo: Editora Brasiliense, 1966.

PRADO, M.L. 'Davi e Golias: as relações entre Brasil e EUA. Século XX". IN: MOTA, C.G. Viagem Incompleta (A Grande Transação). São Paulo, Editora SENAC, 2000 .

PRETI, D. (Org.) Análise de Textos Orais. São Paulo: FFLCH/USP, 2001.

QUEIROZ, F.A. de. A Revolução Microeletrônica: Pioneirismos Brasileiros e Utopias Tecnotrônicas. São Paulo: Annablume/Fapesp, 2007.

REZENDE, M.J. A Ditadura Militar no Brasil - Repressão e Pretensão de Legitimidade - 1964-1984. Editora Eduel, 2000.

RICCI, M. L. S. R. Campinas Vista por Alguns Viajantes Estrangeiros no Século XIX. Rev. Notícias Biliográficas e Histórias, ano XIV n¹05, PUCC/Campinas, 1982.

RIBEIRO, W. C. A Indústria de Armamentos no Brasil. in: VARGAS,Milton(org).História da Técnica e da Tecnologia no Brasil.Editora UnespCentro Estadual de Educação Paula Souza,1994. p.299-314.

RICOEUR, P. A Memória, a História, o Esquecimento. Trad. A. François et al. Campinas, SP: Editora da UNICAMP, 2007. 
RODRIGUES, M. L. V. Inovações no Ensino Médico e Outras Mudanças: Aspectos Históricos da Faculdade de Medicina de Ribeirão Preto. Medicina Ribeirão Preto, 2002, p.231-235.

RODRIGUES, O. Teoria do Subdesenvolvimento. Rio de Janeiro: Forense Universitária, 1981.

ROGERS, E. M.; LARSEN, J. K. Silicon Valley Fever: Growth of High-Tecnology Culture. Nova Iorque, Basic Books, 1984.

SAES, F. A. M. A Grande Empresa de Serviços Públicos na Economia Cafeeira. São Paulo, Hucitec, 1986.

SALIBA, E. T. As Utopias Românticas. São Paulo, Brasiliense, 1991.

SANTOS, R. C. B. Campinas Como Polo Tecnológico na Reestruturação do Espaço Urbano Regional. In. CARLOS. Ana Fani A.; Amália I. G. (Orgs.). Dilemas Urbanos: Novas Abordagens Sobre a Cidade. P.204- 211. São Paulo. Contexto. 2005.

SANTOS, T. El Nuevo Caracter de la Dependencia. Santiago, Centro de Estudios Sócio-Económicos da Universidade do Chile, 1967.

SAXENIAN, A. L. Silicon Chips and Spacial Structure: The Industrial Basis of Urbanization in Santa Clara Valley. California, Berkeley: University of California, Institute of Regional Development, 1981.

SAXENIAN, A. L. The Political Economy of Industrial Adaptation in Silicon Valley. Cambridge, Massachusetts Institute of Technology, Departament of Political Science, Dissertação, 1989.

SAXENIAN, A. L. Regional Networks and the Resurgence of Silicon Valley. California Management Review, 33: 89-112, 1990.

SEMEGHINI, U. C. Do Café à Indústria - Uma Cidade e Seu Tempo. Campinas, Editora da Unicamp, 1991.

SIMSOM, O.R. de M. von. (org.). Os Desafios Contemporâneos da História Oral. Campinas, CMU/UNICAMP, 1997.

SKIDMORE, T. Brasil: De Castello a Tancredo: 1964 - 85. Rio de Janeiro, Paz e Terra, 1988.

SIQUEIRA, T. V. Os Clusters de Alta Tecnologia e o Desenvolvimento Regional. Revista do BNDES, Rio de Janeiro, v. 10, n. 19, p.129-198, jun. 2003. Disponível em: < http://www.bibliotecaflorestal.ufv.br/bitstream/handle/123456789/4209/BNDES_Osclusters-de-alta-tecnologia-e-o-desenvolvimento-regional.pdf?sequence $=1>$. Acesso em 17 fev. 2014.

SOUZA, H.G. et al. Política Científica. São Paulo: Editora Perspectiva, 1972. 
STEINER, G. Linguagem e silêncio - Ensaios Sobre a Crise da Palavra. São Paulo: Companhia das letras, 1998.

SZACKI, J. As Utopias. Rio de Janeiro, Paz e Terra, 1972.

TAVARES, H. M. Complexos de Alta Tecnologia e Reestruturação do Espaço.In: SANTOS, Milton (Org.) et al...Fim de Século e Globalização. 3. ed. São Paulo: Hucitec-Anpur, 1997, p.270-284.

TAVARES, M.C.; SERRA, J. Mas Allá del Estacionamento: Una Discussión Sobre el Estilo de Desarrollo Reciente. El Trimestre Economico, v.XXXII, n.152, out./dez. 1971.

TESLA, N. A Machine To End War. Libertty, Public Broadcasting Service, February/1937.

THOMPSON, P. A Voz do Passado: História Oral. Rio de Janeiro: Paz e Terra, 1992.

UNIVERSIDADE DE BRASÍLIA. Comissão Anísio Teixeira de Memória e Verdade. Brasîlia, 2015.

UMESAO, T. Joho Sangyo Ron. Chuo - kohron, 1963, p.46-58.

VANSINA, J.(1985). Oral Tradition as History. Madison: University of Wisconsin

VARGAS, M. (org).História da Técnica e da Tecnologia no Brasil.Editora UnespCentro Estadual de Educação Paula Souza,1994.

WATERS, C., et al. The Anthropocene is Functionally and Stratigraphically Distinct From the Holocene. Science Magazine, Vol.351, num.6269, Jan 2016. 